\title{
Republic of Croatia: 2010 Article IV Consultation-Staff Report; Public Information Notice on the Executive Board Discussion; Staff Statement; and Statement by the Executive Director for the Republic of Croatia
}

The following documents have been released and are included in this package:

- $\quad$ The staff report, prepared by a staff team of the IMF, following discussions that ended on May 10, 2010, with the officials of the Republic of Croatia on economic developments and policies. Based on information available at the time of these discussions, the staff report was completed on June 3, 2010. The views expressed in the staff report are those of the staff team and do not necessarily reflect the views of the Executive Board of the IMF.

- $\quad$ A Staff statement.

- $\quad$ A Public Information Notice (PIN).

- $\quad$ A statement by the Executive Director for the Republic of Croatia

The policy of publication of staff reports and other documents allows for the deletion of market-sensitive information.

\author{
Copies of this report are available to the public from \\ International Monetary Fund • Publication Services \\ $70019^{\text {th }}$ Street, N.W. • Washington, D.C. 20431 \\ Telephone: (202) 623-7430 • Telefax: (202) 623-7201 \\ E-mail: publications@imf.org Internet: http://www.imf.org
}

\section{International Monetary Fund Washington, D.C.}




\section{INTERNATIONAL MONETARY FUND}

\section{REPUBLIC OF CROATIA}

\section{Staff Report for the 2010 Article IV Consultation}

Prepared by Staff Representatives for the 2010 Consultation with the Republic of Croatia Approved by Adam Bennett and Michele Shannon

June 3, 2010

Discussions. Zagreb, April 28 to May 10, 2010. The mission met with Prime Minister Kosor; Deputy Prime Minister and Finance Minister Šuker; Croatian National Bank (CNB) Governor Rohatinski; other senior officials; and representatives of social partnerships, think tanks, and private sector.

Team: Ms. Murgašová (head), Mr. Atoyan and Ms. Rahman (all EUR), and Mr. Prokopenko (MCM). Mr. Lambregts (OED) also joined the discussions.

Previous IMF advice: At the time of the 2009 Article IV Consultation (concluded on June 2, 2009), Executive Directors stressed the importance of rationalizing public spending and accelerating structural reforms to raise productivity growth. In this regard, they encouraged the authorities to step up efforts to modernize the civil service, improve cost recovery for social services, reduce subsidies and better target social spending. The authorities' recently-adopted Economic Recovery Program (discussed in this report) addresses reforms in many of these areas.

Consultation focus: Discussions focused on policies to increase room for policy maneuver, enhance Croatia's competitiveness to attain sustainable growth, and reduce external vulnerabilities.

Policy advice. The staff advocates: (i) fiscal consolidation through expenditure reforms in public administration, social spending, and privatization; (ii) advancing structural reforms to enhance labor force participation and improve business environment; (iii) income and wage policies to improve competitiveness given the authorities' policy to maintain a broadly stable exchange rate; (iv) careful monitoring of banks' liquidity and credit portfolios.

Exchange rate. De jure managed float with no predetermined path; de facto stabilized under the Fund's classification. Croatia has accepted the obligations under Article VIII, Sections 2, 3, and 4, and maintains an exchange system free of restrictions on payments and transfers for current international transactions. 


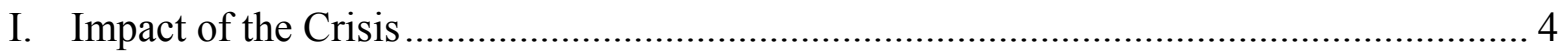

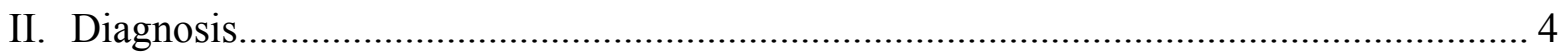

A. Pre-Crisis Growth Relied on Domestic Demand as Competitiveness Declined.......... 4

B. Financial and Macroeconomic Policies Fell Short in Some Areas............................... 6

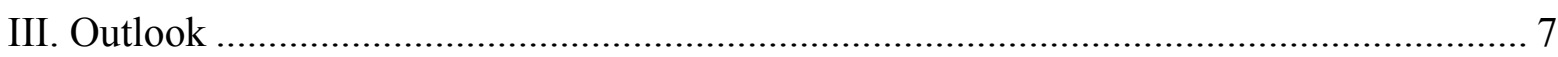

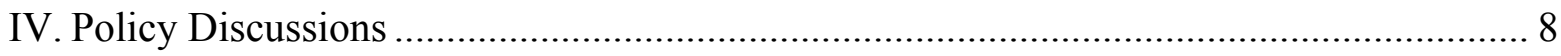

A. Strengthening Fiscal Discipline ………………

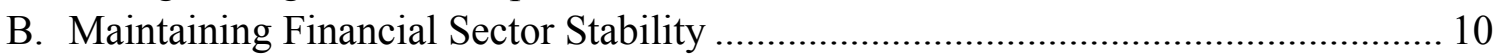

C. Enhancing Competitiveness................................................................................. 12

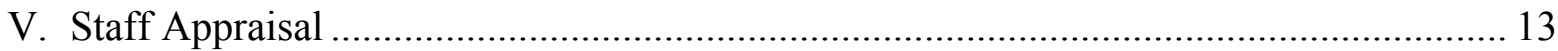

Figures

1. Financial Market Conditions, 2000-10

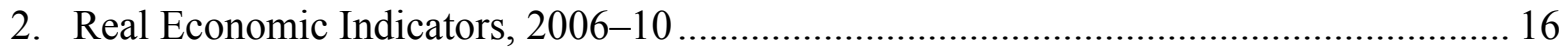

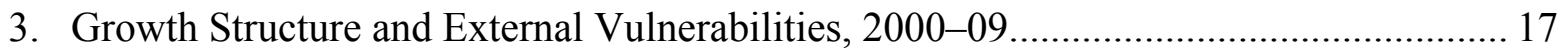

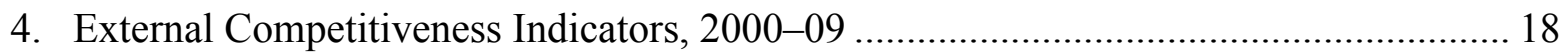

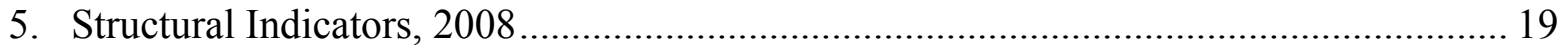

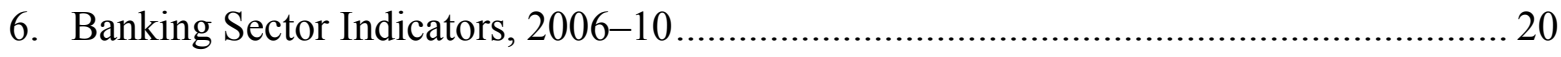

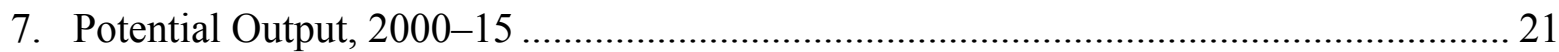

8. Fiscal Scenarios, Unchanged Policies and with Adjustment, 2002-15 ……................. 22

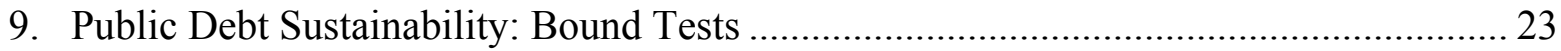

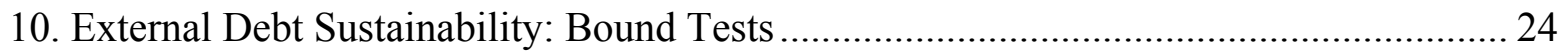

Tables

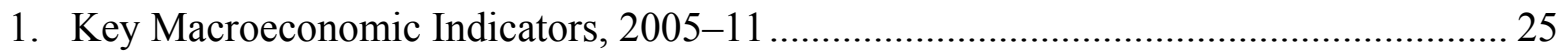

2. Consolidated General Government Finances, 2007-15 _............................................ 26

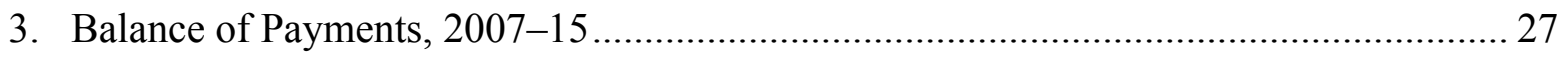

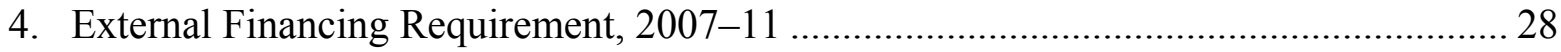

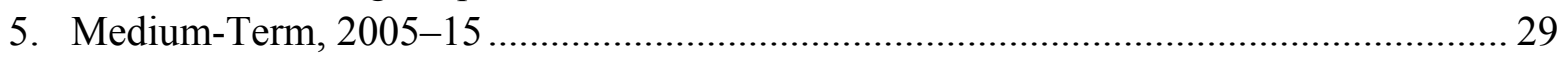

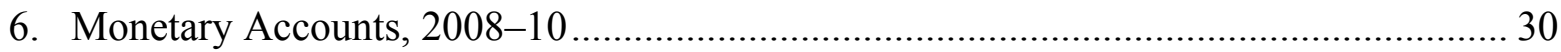

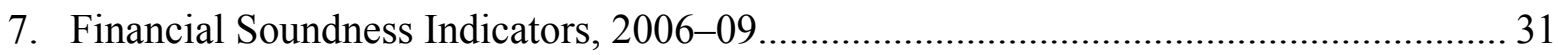

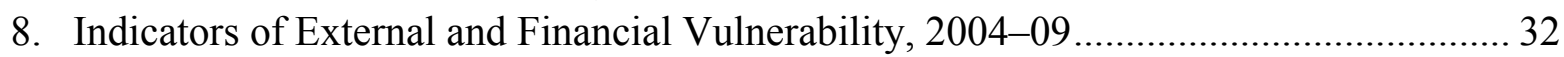

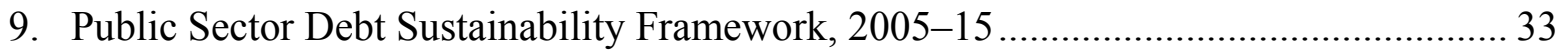

10. External Sector Debt Sustainability Framework, 2005-15 ............................................... 34

Annexes

I. Assessing Croatia's Real Exchange Rate ……….............................................................. 35

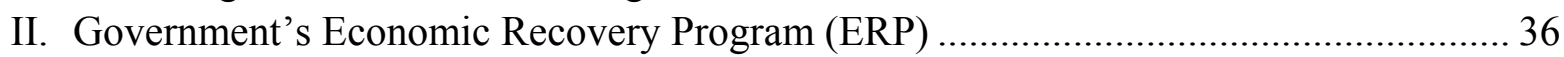

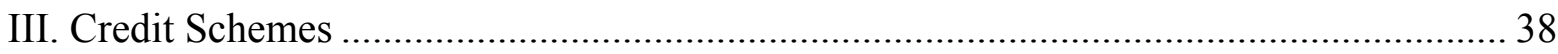




\section{IMPACT OF THE CRISIS}

1. The global economic and financial crisis has significantly affected the Croatian economy (Figure 1). Reduced private capital inflows and external demand aggravated Croatia's existing imbalances. With a large current account deficit, a high level of external debt, and significant balance sheet exposures to interest- and exchange rate-induced risks, market confidence in Croatia deteriorated sharply in early 2009. Financial asset prices collapsed, sovereign spreads shot up, and the Zagreb stock market plunged.

2. The authorities moved swiftly to support macroeconomic and financial stability. The Croatian National Bank (CNB) appropriately addressed liquidity shortages in the banking sector through relaxation of regulatory requirements, repo auctions, and simplified rules for banks to access CNB's emergency liquidity assistance. Intermittent foreign exchange interventions alleviated downward pressures on the kuna. To offset plunging revenues and contain the 2009 budget deficit to financeable levels, the authorities adopted three supplementary budgets with a number of short-term measures. The measures included expenditure cuts, a wage and pension freeze, a VAT rate hike, and the introduction of a temporary "solidarity tax" on incomes and pensions above 3,000 kuna per month. Fiscal Balance and Public Debt (in percent of GDP), 2007-09

\begin{tabular}{llll}
\hline & 2007 & 2008 & 2009 \\
\hline General Government's Fiscal Balance & -1.3 & -1.0 & -3.9 \\
$\quad$ & & & 0.3 \\
$\quad$ One-off Revenue Measures & -0.1 & -0.1 & -0.6 \\
$\quad$ Payment for Shipyard Guarantees & -2.3 & -2.7 & -2.8 \\
Cyclically-Adjusted Fiscal Balance & -3.3 & -2.2 & -4.8 \\
Broader Public Sector Balance 1/ & 33.2 & 29.3 & 35.4 \\
Public Sector Direct Debt & 8.6 & 13.0 & 15.0 \\
Public Sector Guaranteed Debt & & & \\
1/ See footnote 4 in Table 2 for definition of broader public sector. & &
\end{tabular}

Despite this, the general government overall fiscal deficit widened to just under 4 percent of GDP (including the payment for a called guarantee of a public shipyard) and the deficit of the broader public sector grew to almost 5 percent of GDP (text table). Public debt also rose sharply to 50 percent of GDP (including guaranteed debt).

3. The timely policy response has helped improve financial market sentiment. The kuna has fully retracted its losses, official reserves have been replenished, and bond spreads have declined considerably. Croatia successfully tapped international capital markets twice in 2009. Liquidity pressures have abated as domestic deposits have been stable, while credit lines to domestic subsidiaries from foreign parent institutions have been maintained. Banks have weathered the crisis relatively well and have been able to maintain adequate capitalization, although credit quality has worsened significantly and profitability has declined, largely reflecting an increase in the provisioning for nonperforming loans. Private sector credit growth fell sharply, as the uncertain macroeconomic environment lowered demand for new loans and banks tightened underwriting standards. 
4. The economic downturn has, nevertheless, been severe (Table 1, Figure 2). With tight credit conditions and subdued external demand, real GDP has fallen by 5.8 percent in 2009, led by large drops in investment and private consumption, and unemployment rose sharply to 17 percent. Exports plunged on the back of weak external demand, though the decline was more than offset by a reduction in imports. The current account deficit thus nearly halved to 5 percent of GDP. Headline inflation has declined from its peak of 6 percent in mid-2008 to 0.6 percent in April 2010, consistent with a significant negative output gap (about 2 percent of GDP by staff estimates).
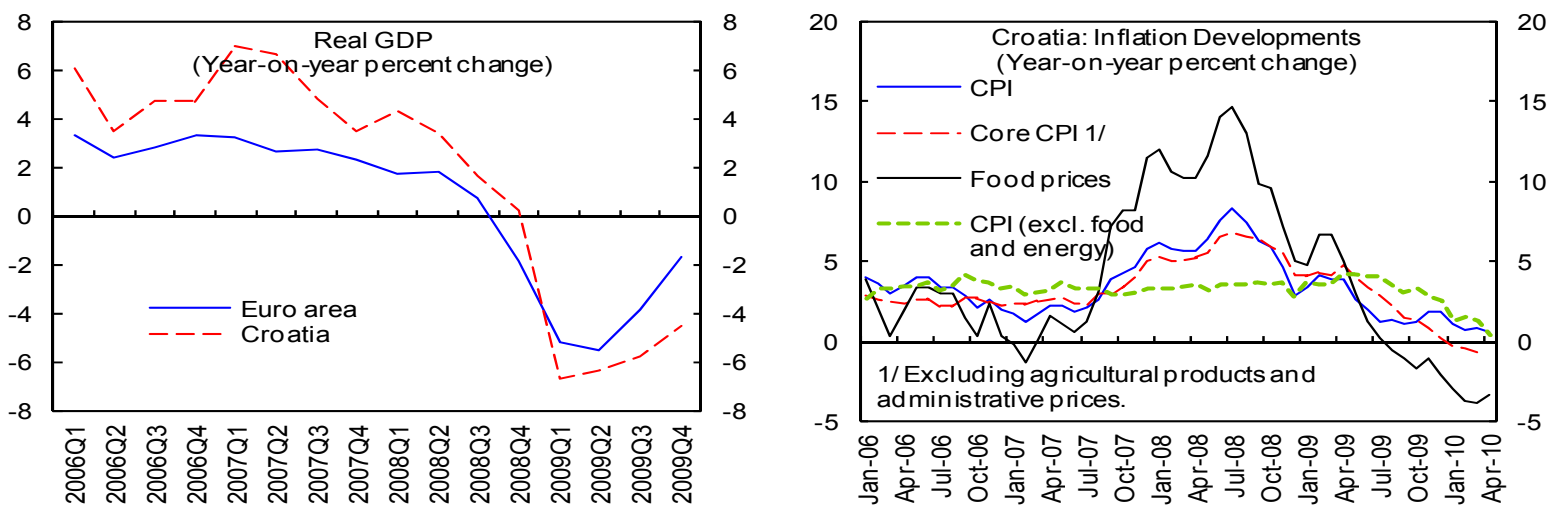

Sources: Rupublic of Croatia Central Bureau of Statistics; and Haver.

\section{Diagnosis}

\section{A. Pre-crisis Growth Relied on Domestic Demand as Competitiveness Declined}

5. The pre-crisis domestic-demand driven growth was built on weak fundamentals (Figure 3). ${ }^{1}$ Abundant foreign capital inflows fueled a credit boom and raised vulnerabilities to historically high levels. Debt dominated the composition of inflows, while much of the foreign direct investment (FDI) went into the financial and wholesale/retail trade sectors. Notwithstanding the CNB's efforts to lean against large capital inflows through prudential and regulatory measures, the foreign-owned banking system revved up credit growth, including through cross-border borrowing. Most of this borrowing financed activities in the non-tradable sector, exacerbating its already pronounced bias in the structure of Croatia's economy. As a result, during 2001-08, private consumption and investment (mostly in the construction sector) became the main drivers of economic growth, while net exports made a negative contribution.

6. Weak export performance points to competiveness problems (Figure 4). Trade deficits remained high even by regional standards, penetration into world export markets was

\footnotetext{
${ }^{1}$ See "Beyond the Crisis: Revisiting Emerging Europe's Growth Model," by Ruben Atoyan, IMF Working Paper No. 10/92.
} 
meager, and Croatia's economy remained relatively closed. ${ }^{2}$ Tourism receipts, which account for half of exports of goods and services, failed to benefit from large-scale FDI inflows during the boom years. A prolonged period of nominal exchange rate stability and structural rigidities in the economy likely played a role.

\section{Price and cost indicators suggest that competitiveness has been deteriorating in} recent years (Figure 4). Staff's quantitative estimates show that the real effective exchange rate could be slightly overvalued (Annex 1). Also, Croatia's unit labor costs rose significantly faster relative to those in trading partners-wages in the private sector were likely pushed up by rapid wage growth in the public sector in pre-crisis years (text figure).

Consequently, the overall wage level appears high relative to Croatia's productivity and income level. This reflects non-competitive wage setting

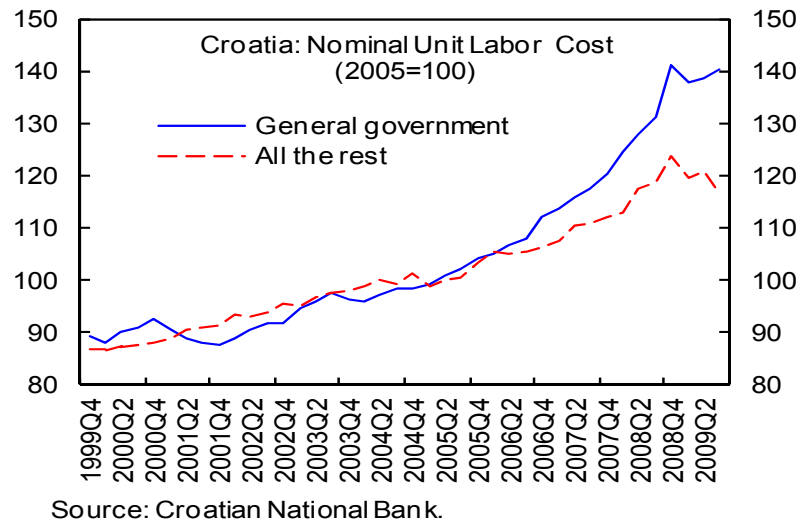
and strong trade union presence in the public sector, which employs a quarter of the labor force, excluding public enterprises.

8. Croatia's economy is also saddled with more pervasive rigidities and higher government involvement than many of its transition peers (Figure 5). These dampen labor market participation, hamper the emergence of a dynamic private sector, and add to fiscal costs.

- Incomplete privatization. Almost two decades after the beginning of transition, Croatia lags behind its European peers in large-scale privatization, enterprise restructuring and competition policy. Continued provision of state subsidies has become a fiscal burden and kept production in the hands of a few large firms.

- Rigid labor market and low participation. Strict labor regulations severely constrain labor market flexibility, resulting in high employment in the gray economy, proliferation of temporary work contracts, and reduced employers' incentives to expand employment during the boom years. Retirees account for about a quarter of Croatian population reflecting generous pension and social benefits conditions, which poses a burden on the employed and contributes to labor shortages. An aging population is likely to further aggravate these pressures.

\footnotetext{
${ }^{2}$ In 2000-09, Croatia's exports of goods and services averaged at around 45 percent of GDP, well below the $55-$ 65 percent of GDP range for most other countries in Central and Eastern Europe.
} 
- Restrictive and costly business environment. Croatia's business regulations are cumbersome. For example, it takes twice as long to register a business in Croatia compared to the regional average. Moreover, para-fiscal fees at the local government level (over 200 categories) add to the costs and uncertainty of doing business. In general, the state exercises excessive control in strategic decisions in public enterprises.

\section{B. Financial and Macroeconomic Policies Fell Short in Some Areas}

\section{The CNB pursued proactive policies, which helped ensure financial sector} stability. Since 2003, the CNB used a variety of conventional (higher reserve requirement and higher risk weights for unhedged foreign currency loans) and unconventional measures (credit ceilings, marginal reserve requirements on foreign borrowing, and foreign currency liquidity requirements) to limit the increase in vulnerabilities associated with the rapid growth of bank credit. These measures built up liquidity and capital buffers which contained pressures as the crisis unfolded. This, together with the transfer of credit risk to the books of their foreign parents, has enabled the banks to withstand the deterioration in credit quality that has occurred since early 2009.

\section{A stable nominal exchange rate provided an anchor for inflation expectations} and financial stability, but also contributed to the accumulation of vulnerabilities. Monetary policy was geared toward maintaining a broadly stable kuna exchange rate. However, this de-facto fixed exchange rate regime reduced perceptions of the exchange rate risk and contributed to the overleveraging in foreign currency(text figure). Croatia's external debt increased rapidly reaching over 95 percent of GDP in 2009, half of which is owed by the corporates. Financial euroization-

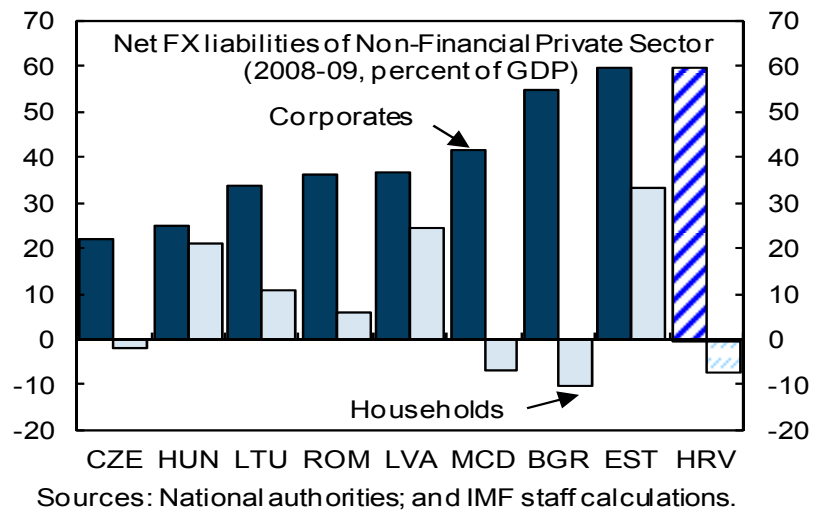
traditionally high in Croatia - increased during the crisis: at end-December 2009, about 70 percent of the total bank credit and over 65 percent of bank deposits were denominated in or indexed to foreign currency.

\section{Croatia's fiscal policy did not take sufficient advantage of the boom years to} create adequate space for demand management (Table 2). ${ }^{3}$ While the cyclically-adjusted fiscal balance was improved by an impressive 3 percentage points of GDP during 2004-06, it

\footnotetext{
${ }^{3}$ See "Absorption Boom and Fiscal Stance: What Lies Ahead in Eastern Europe?" by Jesmin Rahman, IMF Working Paper No. 10/97.
} 
was then relaxed during 2007-08. Challenging reforms in the public sector were left untackled, creating rigidities in public expenditure. As a result, at the onset of the crisis, Croatia found itself with constrained policy space, unable to support growth with a fiscal stimulus.
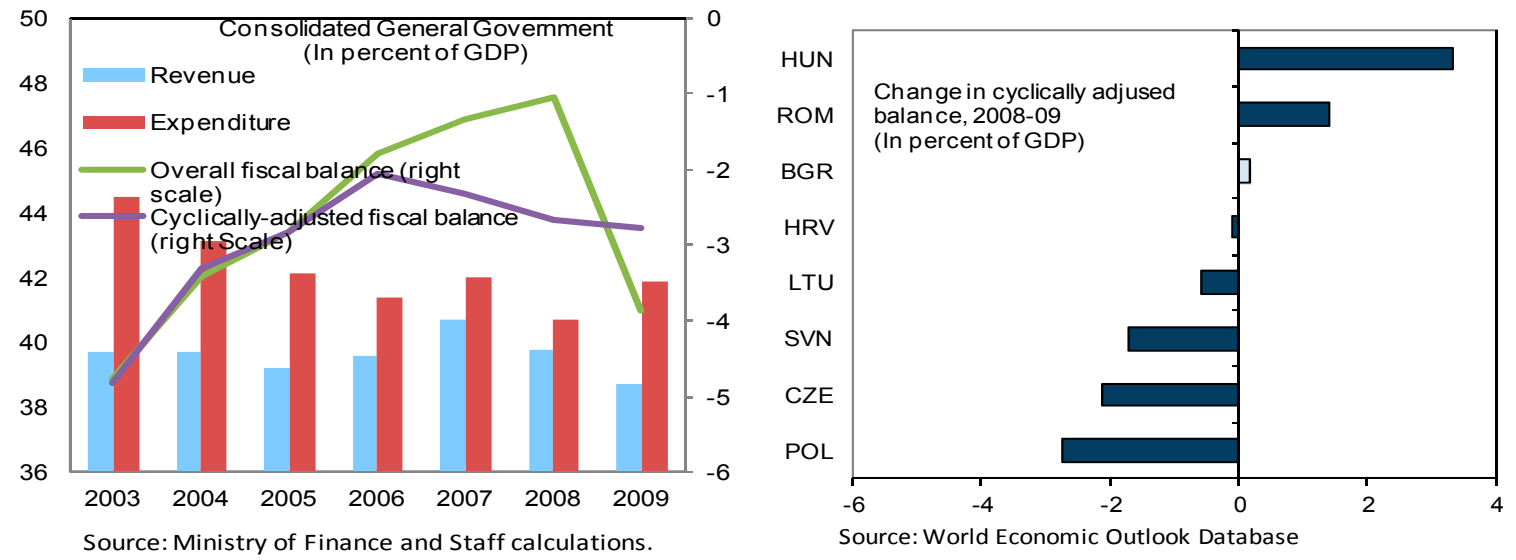

\section{OUTLOOK}

12. Economic recovery is expected to be gradual, with positive growth resuming in the second half of 2010 (Table 1). The outcome for the first quarter of this year remains mixed: while the fall in industrial production has stopped and retail services show signs of stabilization, the construction sector continues to contract. Falling disposable incomes and profits, rising unemployment, weak credit conditions, and private sector indebtedness are likely to hold back consumption and investment. The recovery in the second half of the Growth and Inflation Forecast Comparison 1/

\begin{tabular}{lcccccc}
\hline & \multicolumn{2}{c}{ Real GDP growth } & & \multicolumn{2}{c}{ Average CPI inflation } \\
\cline { 2 - 3 } \cline { 6 - 6 } & 2010 & 2011 & & 2010 & 2011 \\
\hline IMF & 0.0 & 2.0 & & 2.0 & 2.7 \\
World Bank & 0.3 & 2.9 & & 2.2 & 2.7 \\
EBRD & 0.3 & 1.8 & & $\ldots$ & $\ldots$ \\
Economist Intelligence Unit & 0.2 & 2.2 & & 2.3 & 2.6 \\
Consensus Forecast & -0.4 & 2.2 & & 2.3 & 2.9 \\
\hline
\end{tabular}

1/ As of April-May, 2010. year-mainly driven by net exports and inventories' restocking-is thus likely to be fragile. Overall, the staff expects zero economic growth and an average inflation of about 2 percent in 2010 (text table).

\section{External financing needs will remain substantial but, absent contagion, private} capital inflows should be sufficient (Table 3). The current account deficit is projected to remain broadly stable at around 5 $\frac{1}{2}$ percent of GDP on the back of a tepid economic recovery. Nevertheless, the sizable currect account deficit and the large stock of maturing external debt, mostly private, imply a significant external financing need (40 percent of GDP) in 2010 (Table 4). The weak economic outlook will continue to hold back FDI inflows. However, parent banks appear to be committed to maintain exposure to local subsidiaries and corporate clients (as they did during the crisis), and are expected to continue facilitating sufficient rollover of maturing private sector debt. 
14. Risks to the near-term outlook are tilted to the downside. Croatia remains vulnerable to contagion risks from adverse market sentiment in the region. This could be manifested in tightening financial constraints - a rise in borrowing costs, or a reduction in cross-border flows. In addition, weak fiscal fundamentals in Croatia and large financing needs could telescope into short-term financing strains. However, the absence of Greek banks in Croatia and the limited real sector linkages with Greece should minimize the risks of direct spillovers. Moreover, the diversity of parent bank countries (Austria, Italy, France, Germany, and Hungary) should reduce the vulnerability of Croatian banking system to sudden funding pressures from abroad, unless these encompass the euro area as a whole.

15. Over the medium-term, growth is unlikely to recover to its pre-crisis trend and vulnerabilities will remain high (Figure 7, Table 5). The authorities and the staff agreed that heightened global risk aversion makes it unlikely that capital inflows will return to precrisis levels, thus curbing future credit and domestic demand growth. A highly-leveraged household sector will further weigh down credit growth, while poor competitiveness will not allow exports to take full advantage of a euro area recovery, and a lack of fiscal space will limit the scope for fiscal stimulus. The output gap may close as early as 2012 , but mediumterm potential growth is projected at 3 percent, falling significantly short of its pre-crisis level (Figure 7). Similarly, vulnerabilities will remain large with an external debt-to-GDP ratio hovering around 100 percent, and the reserve coverage of short-term debt staying well below 100 percent (Table 3).

\section{Policy Discussions}

16. The policy discussions centered on the authorities' medium-term strategy of Croatia's integration with the European Union (EU). The authorities view EU accession as a near-term priority that would bolster market confidence and guide the reform agenda, and euro adoption as a subsequent objective that would anchor their exchange rate policy. Discussions focused on the set of policies needed to serve this goal, including reforms envisaged in the recently-adopted Economic Recovery Program (ERP) that are intended to enable Croatia reap the maximum benefit of accession, and taking into account the authorities' strong commitment to continuity in the exchange rate regime.

\section{A. Strengthening Fiscal Discipline}

\section{The sizable fiscal consolidation envisaged in the original 2010 budget} appropriately addresses financing constraints and crowding out concerns, but is unlikely to materialize without additional expenditure cuts (Table 2). The 2010 budget incorporates the full-year impact of tax measures adopted last year and a nominal expenditure freeze. However, with a worsened growth outlook and the authorities' plan for an early withdrawal of the solidarity tax and a reduction in personal income tax rates from mid-2010, the staff projects the fiscal deficit to reach 3.6 percent of GDP (broadly unchanged from 2008 on a cyclically-adjusted basis) versus 2.7 percent of GDP estimated in the budget. 
The staff projects the broader public sector deficit to remain at 5 percent of GDP and public sector debt, inclusive of guaranteed stock, to rise further to 54 percent of GDP. The authorities indicated their intention to propose a supplementary budget to contain the deficit.

18. The authorities and the staff agreed that the financing gap (6 percent of GDP) is sizable but likely manageable given recent strong demand for government securities by domestic banks. Nevertheless, with over 60 percent of the debt stock denominated in foreign currency and one third in short-term maturities, financing is subject to exchange rate and rollover risks. Additional fiscal risks relate to the likely execution of outstanding government guarantees on shipyards that could reach up to an additional 2 percent of GDP in 2010, as well as possible revenue underperformance in the event of a longer-than-expected recession.

19. In the medium term, staff estimates suggest that unchanged policies would keep the general government fiscal deficit above the Maastricht criterion of 3 percent of GDP, with the public debt stock on a rising trend (Table 2, Figure 8). The lifting of the temporary tax measures in 2010 and reductions in personal income tax rates will reduce the revenue-to-GDP ratio in 2011 , but this will slowly recover as employment goes back to its potential and

\begin{tabular}{lcccccccc}
\multicolumn{7}{c}{ Medium-term Fiscal Developments of the General Government, 2009-15, Unchanged Policy Scenario (in percent of GDP) } \\
\hline
\end{tabular}
transfers increase with Source: Ministry of Finance and Staff Estimates. approaching EU accession. Meanwhile, expenditure rationalization from structural measures already in place will result in modest savings, likely to be offset by increasing interest payments. ${ }^{4}$ As a result, the general government deficit is expected to stay above $3 \frac{1}{2}$ percent of GDP (text table). The broader public sector deficit would remain around 5 percent of GDP, though with considerable upward risks depending on the performance of the off-budget entities. To the extent EU accession would raise expenditure through co- financing needs, the fiscal deficit could further worsen, absent compensating measures. The total stock of public debt, including guarantees, will likely rise above 60 percent of GDP, raising sustainability concerns.

\footnotetext{
${ }^{4}$ Structural reforms undertaken in 2009 consist of the passage of a new compulsory health insurance act, reduction of the maximum level of unemployment benefits, introduction of personal tax identification numbers, and reduction in privileged pensions of government officials, members of the parliament, and judiciary. These measures are assumed to reduce social benefits expenditure by half a percent of GDP in the medium-term.
} 
20. A more appropriate medium-term fiscal target would be a cyclically-balanced budget that would create adequate space for countercyclical maneuvers in the future and also put public debt on a downward path (Figure 8). For a small open economy with a de-facto pegged exchange rate regime, the mediumterm fiscal position needs to create maximum room for demand management. Staff estimates show that maintaining a cyclicallyadjusted zero balance in the medium-term would create

\begin{tabular}{|c|c|c|}
\hline \multirow[b]{2}{*}{ Policy Areas } & \multicolumn{2}{|c|}{ Savings (in percent of GDP) } \\
\hline & Short-term & Medium-term \\
\hline $\begin{array}{l}\text { 1. Reduction of public employment and rationalization } \\
\text { government operations }\end{array}$ & $0.1-0.3+$ & $0.2-0.8+$ \\
\hline $\begin{array}{l}\text { 2. Reform of pension parameters, reduction of previleg } \\
\text { sector reform }\end{array}$ & $1.2-1.3$ & $1.7-1.8$ \\
\hline 3. Improved targeting of social benefits and assistance & $0.2-0.6$ & $0.2-0.6$ \\
\hline 4. Reduction of subsidies & $0.2+$ & $0.2+$ \\
\hline Total & $1.7-2.4+$ & $2.3-3.4+$ \\
\hline
\end{tabular}
enough space to absorb revenue losses resulting from an output gap of up to $3 \frac{1}{2}$ percent without exceeding the Maastricht deficit limit. Achieving such a balance by 2014 would require an adjustment of less than 1 percent of GDP per year, a goal the authorities had achieved previously during 2003-06. Given Croatia's high tax rates, and numerous inefficiencies in public expenditure, this consolidation should be achieved via expenditure cuts in priority areas identified by past FAD technical assistance missions, namely public administration, health, pension, and subsidies, and better targeting of social assistance expenditure (text table).

\section{The authorities' recently-adopted ERP aims for fiscal reforms (Annex 2). It} targets fiscal consolidation as well as many of these expenditure reforms. The staff urges the authorities to frontload measures that would curtail expenditure: reducing the size of the public administration, completing reforms in pension, health and social assistance expenditures, and stepping up privatization. Only after implementing these reforms would there be room for tax reductions which should further stimulate long-term growth. The staff, therefore, advises the authorities to reconsider their current sequencing of reforms, where tax cuts precede difficult expenditure reforms. The staff welcomes the decision to adopt a Fiscal Responsibility Law and encourages the authorities to set the medium-term target ambitiously at a cyclically-adjusted zero balance.

\section{B. Maintaining Financial Sector Stability}

22. Ensuring a smooth resolution of the asset deterioration is a key priority. The ratio of nonperforming loans to total loans (NPL ratio) has been steadily increasing, and reached 7.8 percent at end-2009 (Table 7). The profitability of banks has declined, largely reflecting increased provisioning. However, the aggregate capital adequacy ratio (CAR) has remained stable at around 16.0 percent throughout 2009, well above the minimum regulatory CAR, partly reflecting a growing share of government securities in bank assets. Asset quality is expected to deteriorate further in light of weak growth prospects (even in the baseline scenario). Nevertheless, results of recent stress tests conducted by the CNB suggest that most banks would be able to withstand a significant rise in NPLs. The CNB's decision to increase 
the minimum CAR from 10 percent to 12 percent from April 1, 2010, to ensure a broadly unchanged level of capital buffers in connection with the adoption of the Basel II framework, was appropriate. ${ }^{5}$

23. Liquidity indicators have marginally improved in late 2009, but vulnerability of banks to liquidity risk remains. This risk may arise from funding pressures from abroad, particularly as Croatian banks have substantial external liabilities; as well as the significant domestic refinancing needs of the government. Close monitoring of the situation therefore remains appropriate. Regarding the deposit insurance fund, the recent recapitalization of public banks using the resources of this fund is a matter for concern: ailing banks should be recapitalized by the owners of these banks, not by the deposit insurance fund, whose resources should be invested in liquid assets. The authorities view this as a temporary solution.

24. While the authorities' concerns about a lack of credit recovery are justified, the recently introduced measures to stimulate bank lending to the economy require caution. The three schemes involve (i) the conditional reduction of reserve requirements for increasing the supply of loans to finance working capital and improve liquidity of corporates, (ii) the provision of government guarantees on long-term investment loans, and (iii) the conversion of debt to the government, owed by companies in financial difficulty, into government equity (Annex 3). The combined size of the schemes remains modest (less than 3 percent of GDP, if fully implemented) and safeguards against weakening of credit underwriting standards are in place. Nevertheless, the staff calls for close supervision of the quality of the issued loans and risk management practices of banks involved in these schemes. The fiscal risks from a rising stock of government contingent liabilities also require special attention. Furthermore, the proposed scheme to exchange debt of troubled companies to the government into equity goes against the spirit of intended privatization efforts and should only be used for companies with viable restructuring plans.

25. Despite low inflation pressures and a sizable output gap, the authorities and staff agreed that the monetary stance should not be eased further in the short run. This is because excess reserves of the banking system remain sizable, and the credit support schemes have been slow to take off. In addition, market confidence remains brittle and the financing outlook is susceptible to risks.

26. The existing exposures of the financial sector highlight the need for an effective financial sector policy framework. The overall financial sector regulatory and supervisory framework is effective, and the few weaknesses identified by the 2007 Financial Sector

\footnotetext{
${ }^{5}$ According to the CNB's calculations, the adoption of the Basel II framework since April 1, 2010, increased the aggregate capital adequacy ratio of the banking system by around 2 percentage points, reflecting the decrease in risk weights on foreign currency loans.
} 
Assessment Program have been subsequently addressed. However, there is room to strengthen inter-agency coordination on crisis preparedness and management: although a memorandum of understanding between the Ministry of Finance, the CNB, and the HANFA (the supervisor of nonbank financial institutions) was signed in November 2009, no formal meeting of the signatories of this memorandum has yet taken place.

\section{Enhancing Competitiveness}

27. The authorities are strongly committed to continue a broadly stable exchange rate. While recognizing the difficult trade-offs they face in deciding on the appropriate exchange rate policy, they emphasized that adjustments in the exchange rate would be costly given the economy's large net foreign currency exposure. In staff's view, with negative net positions of corporate and public sectors at 64 and 23 percent of GDP respectively, the balance sheet deterioration that would result from even a moderate nominal depreciation of the kuna would be significant, particularly if limits of existing debt restructuring mechanisms and the potential for negative feedback loops (including through declining growth with adverse implications for public sector finances, banking sector balance sheets, and external debt ratios) are recognized. ${ }^{6}$ Furthermore, while a more flexible regime would improve competitiveness of export-oriented sectors, these gains could be muted by still constrained growth in trading partners and the relatively inward-oriented structure of Croatia's economy. The authorities also consider that it would be difficult to conduct a gradual depreciation in an orderly way, given the high market sensitivity to even small changes in the exchange rate.

\section{Maintaining a stable exchange rate will require significant internal adjustment} to ensure that the necessary gains in competitiveness are made. This would involve competitiveness-enhancing income policies relying on negotiations of wage restraints with labor unions in return for the expectation of higher growth, with the public sector taking the lead. Internal adjustment will likely result in a period of inflation below that of trading partners, slower growth in the near term, and higher nonperforming loans. The costs will be evident from the start, but the growth pay-off will only materialize over the medium-term.

\section{The authorities acknowledged the need to rebalance growth from the} nontradable to the tradable sectors and stressed the role of structural reforms. The ERP aims to reduce the role of the state in the economy through sales of minority shares, improve labor market flexibility through limiting the time length for unemployment benefits, and reduce business costs through the reduction of para-fiscal fees and judiciary reforms. The

\footnotetext{
${ }^{6}$ While it is difficult to estimate the full balance sheet impact of exchange rate changes (including in light of uncertainty regarding second round effects), back-of-the-envelope estimates suggest that the first round effects of a 10 percent nominal devaluation could worsen the overall net position of non-financial sector balance sheet by some 7 percent of GDP. Debt sustainability analysis indicates that a 30 percent real depreciation could increase public and external debt to about 60 percent and 140 percent of GDP, respectively (Figures 9 and 10).
} 
staff supports these measures and advocates their forceful implementation to improve the business environment. At the same time, the staff urges actions to introduce greater flexibility in the Labor Law in order to reduce firing costs that would positively impact job creation.

\section{Staff Appraisal}

30. The staff commends the authorities for skillfully navigating through the global financial and economic crisis. The swift policy measures taken in 2009 aimed to preserve stability in the financial sector and contain fiscal deficits paid off. After an initial plunge in financial markets and sharp declines in revenues, the authorities' actions helped restore stability. Croatia managed to maintain investor confidence, retained access to international capital market, and rolled over maturing debt.

31. Although the Croatian economy is bottoming out, it faces stagnation in 2010 before recovering in 2011. The staff expects a fragile recovery in the second half of 2010 , driven by inventory restocking and the external sector, as the fall in domestic demand slows down. Growth could resume to 2 percent in 2011. This growth path is, however, subject to considerable downside risks, given uncertain global outlook, unsettled financial markets and large vulnerabilities of the economy.

\section{The authorities should continue with vigilant monetary and financial sector}

policies. The moderate pace of recent monetary easing is adequate against the background of a stable foreign exchange market and subdued inflation outlook. While the credit support measures include safeguards to prevent weakening of the credit underwriting standards, close supervision of the quality of the issued loans is needed. In light of sizable excess reserves and the slow take off of the credit schemes, the staff would advise against further monetary easing in the short term as confidence remains weak and financial outlook uncertain.

\section{The crisis has exposed fundamental weaknesses in the Croatian economy and} policies should create foundations that would allow the country to reap the maximum benefits of EU accession. The pre-crisis growth model, fueled by foreign capital and domestic absorption, has created mounting vulnerabilities, weakened competiveness and generated growth that could easily be reversed by changes in international financial conditions. Future capital inflows and credit growth are unlikely to be repeated in light of the heightened global risk aversion. Croatia thus needs to create an open, flexible and competitive economy that could attract quality investment enabling the economy to experience robust growth without piling up imbalances. To attain such a goal, strong complementary macroeconomic and structural policies are needed.

34. The authorities face a difficult choice of the exchange rate regime, as both options are costly. The authorities' strong preference for a broadly stable exchange rate policy implies the need for other measures to be adopted to strengthen competitiveness. Croatia would, inter alia, need to maintain a sustained period of inflation below those of 
partner countries. The staff urges the authorities to pursue income and wage policies that would improve competitiveness, with public sector taking the lead.

35. The staff recommends a strong fiscal consolidation in the medium-term. In the absence of exchange rate flexibility, the burden of demand management falls largely on fiscal policy. The authorities should bring the budget to structural balance over the medium-term to provide adequate room for counter-cyclical measures, and ensure debt sustainability. This should be achieved mainly by expenditure consolidation via a reduction in public sector employment and subsidies to loss-making public enterprises, and a better targeting of social assistance expenditure. In addition, rising contingent fiscal liabilities need to be contained. The authorities' intention to adopt a Fiscal Responsibility Law is welcome, and staff urges them to be ambitious in setting the deficit target.

36. Structural policies should aim to remove existing inefficiencies in the labor market and business environment. Greater flexibility needs to be introduced in employment termination procedures. The staff also advises the revision of social benefit parameters, particularly for pension and unemployment benefits, which create adverse incentives for labor force participation. Improving business environment requires a vigorous pursuit of privatization (including of companies with majority government ownership), reduction of para-fiscal fees, and simplification of business entry requirements.

\section{The Government's recently-announced ERP is a commendable and} comprehensive plan, and its speedy and well-sequenced implementation will be instrumental. The staff urges the authorities to frontload measures that would reduce public expenditure and eliminate structural rigidities in labor market and business environment. The envisaged tax cuts should come into effect only after enough fiscal room has been created through reductions in inefficient public expenditures. The success of the ERP will require considerable political consensus. Its timely and well-sequenced execution will help instill market confidence and enable Croatia to enter the EU from a position of strength.

38. It is proposed that the next Article IV Consultation with Croatia be held on the standard 12-month cycle. 
Figure 1. Croatia: Financial Market Conditions, 2000-10

Bond spreads and CDS spreads have moderated since the peak, but remain above pre-crisis levels.

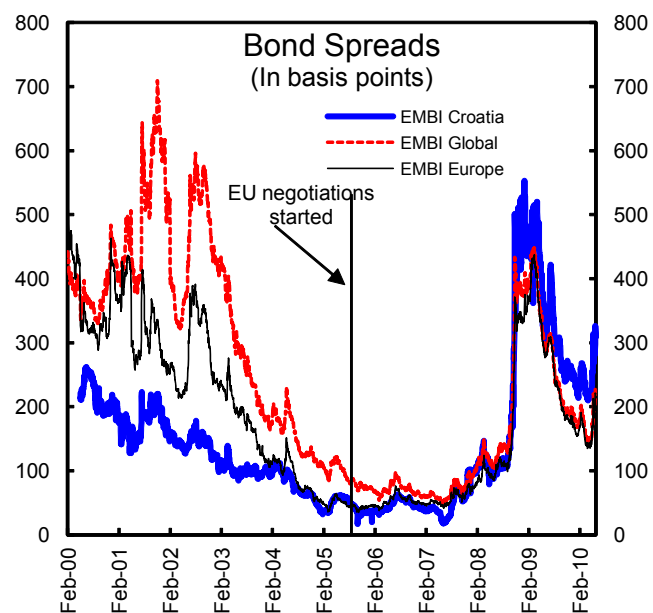

Stock prices have started to recover.

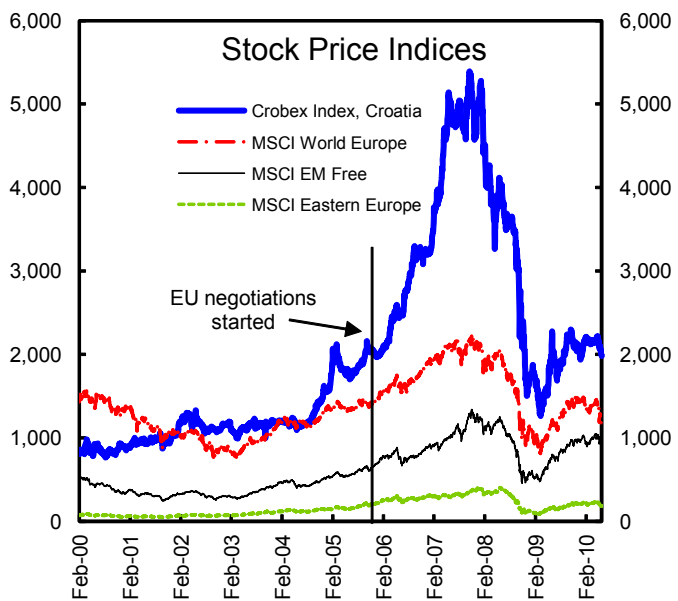

With pressures moderating, the exchange rate has been stable...

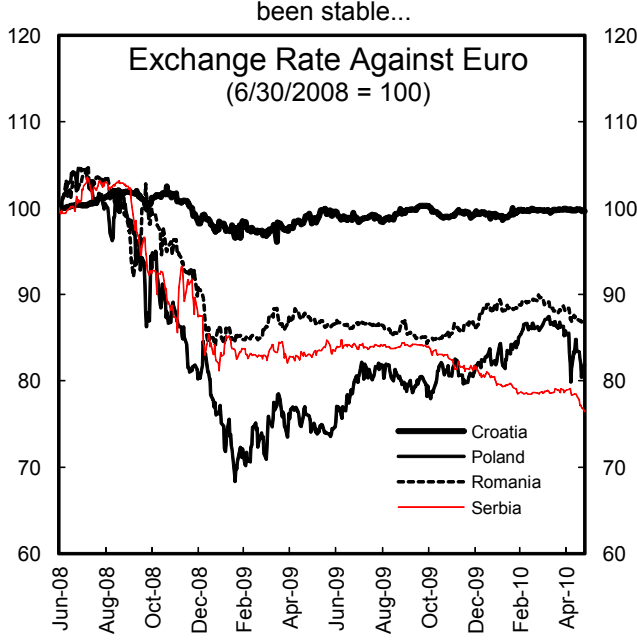

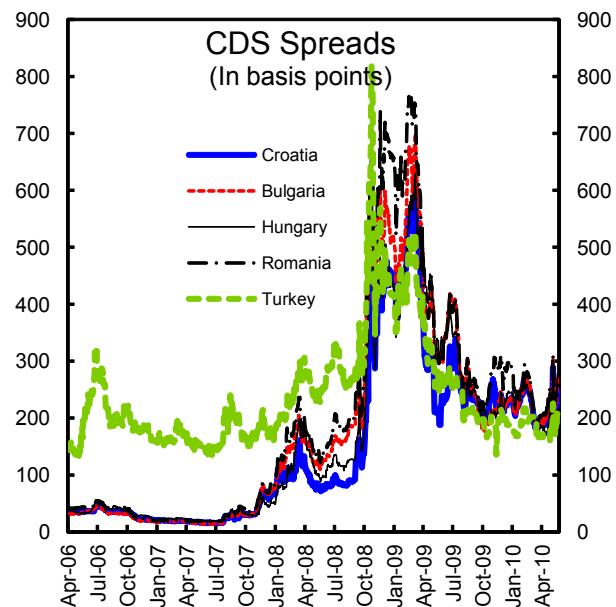

Interbank rates have fallen but banks' retail lending rates are still elevated.

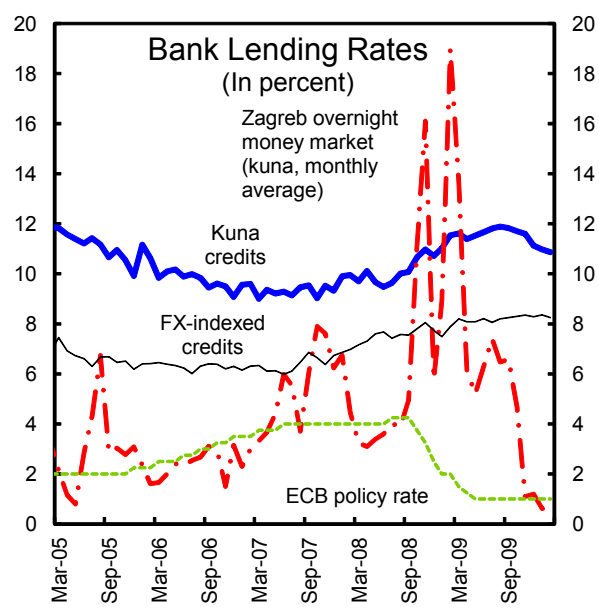

....and reserves have been more than replenished

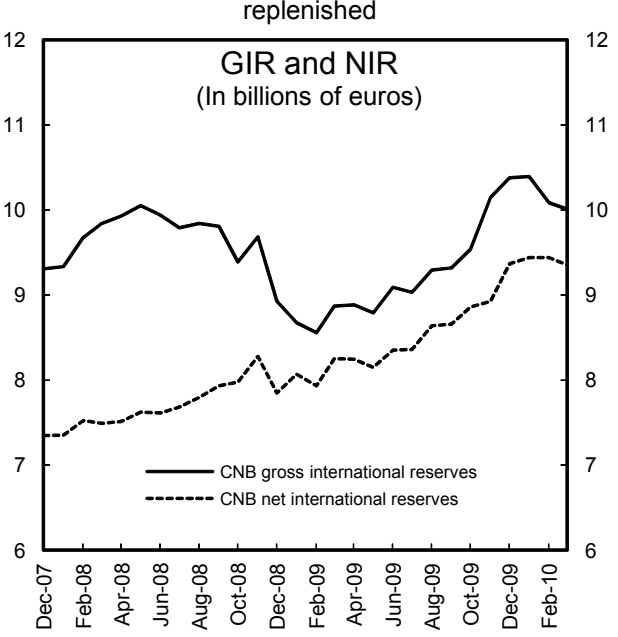

Sources: Croatian National Bank; Haver Analytics; and JP Morgan/Bloomberg. 
Figure 2. Croatia: Real Economic Indicators, 2006-10

The pace of economic decline has started to slow ...

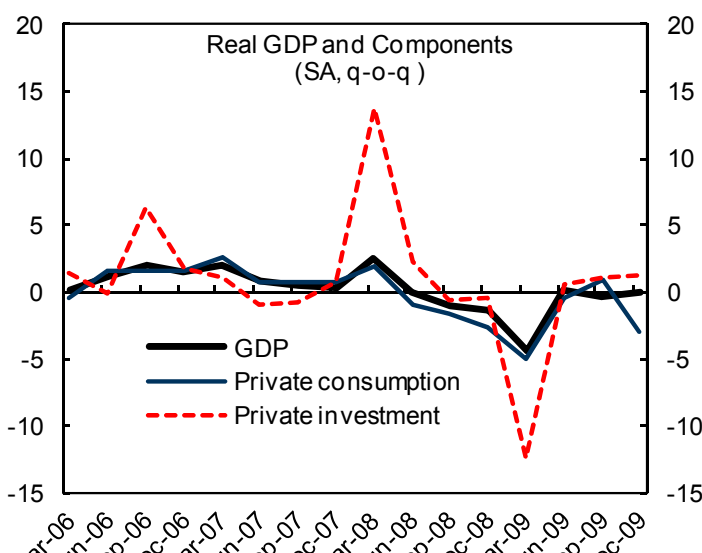

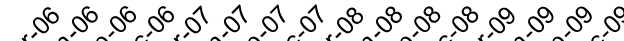
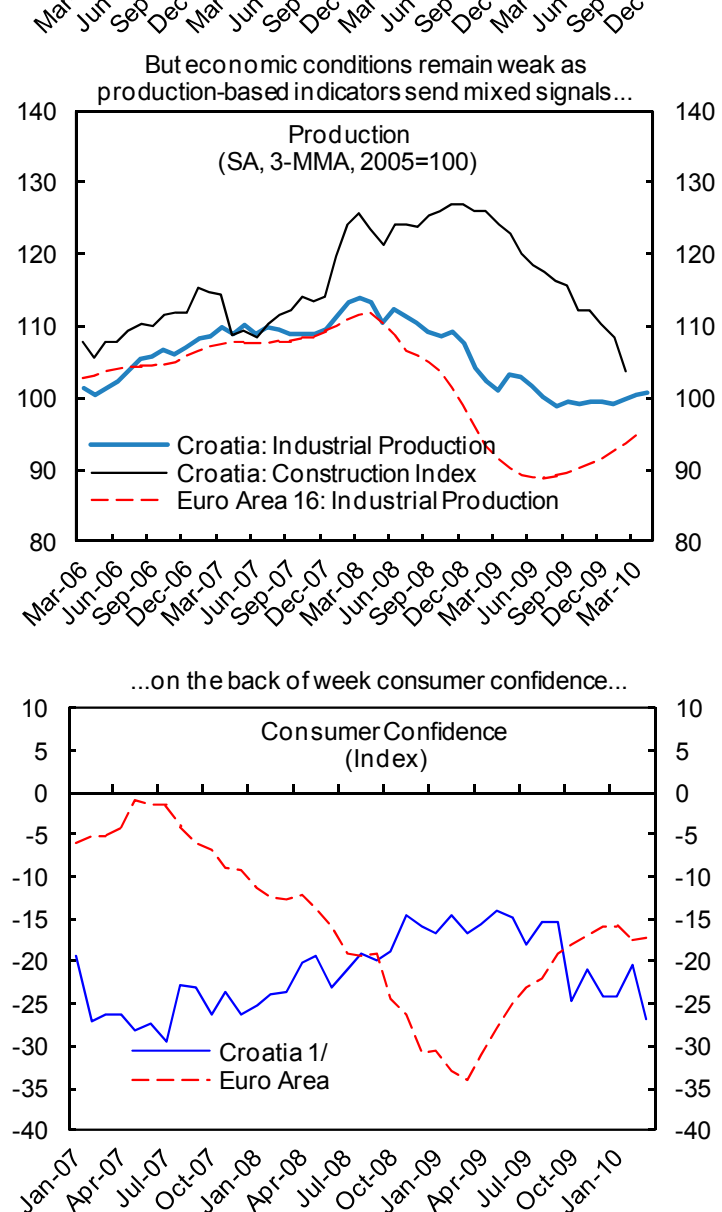

...and the fall in international trade has slowed down.
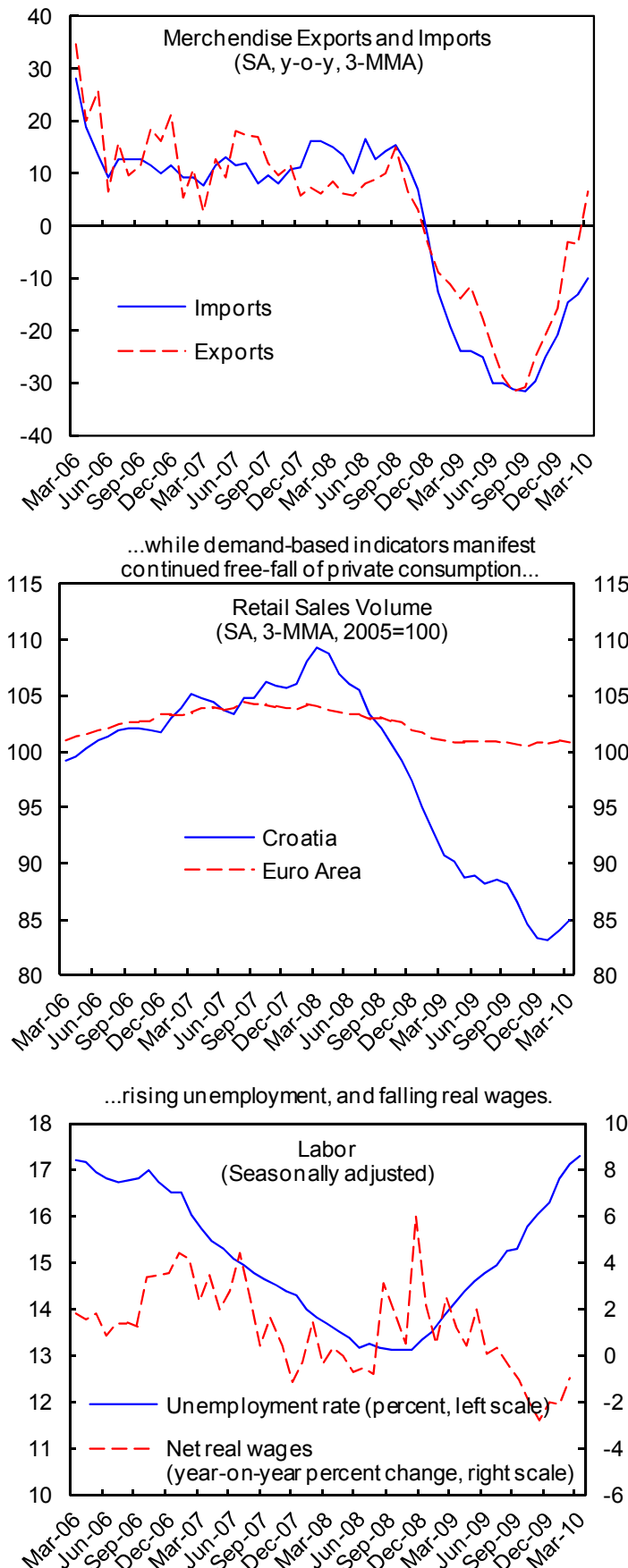

Source: Haver; Eurostat.; European Commission; Republic of Croatia Central Bureau of Statistics; and IMF staff estimates.

$1 /$ The questionnaire contains 23 questions, examining consumer perception of the changes in every-day economic issues. The value of the response index is based on the responses to the questions from the Consumer Confidence Survey. The value of the indices ranges $-100<1<100$. Higher index values than those recorded over the previous period point to an increase in expectations (optimism). 
Figure 3. Croatia: Growth Structure and External Vulnerabilities, 2000-09
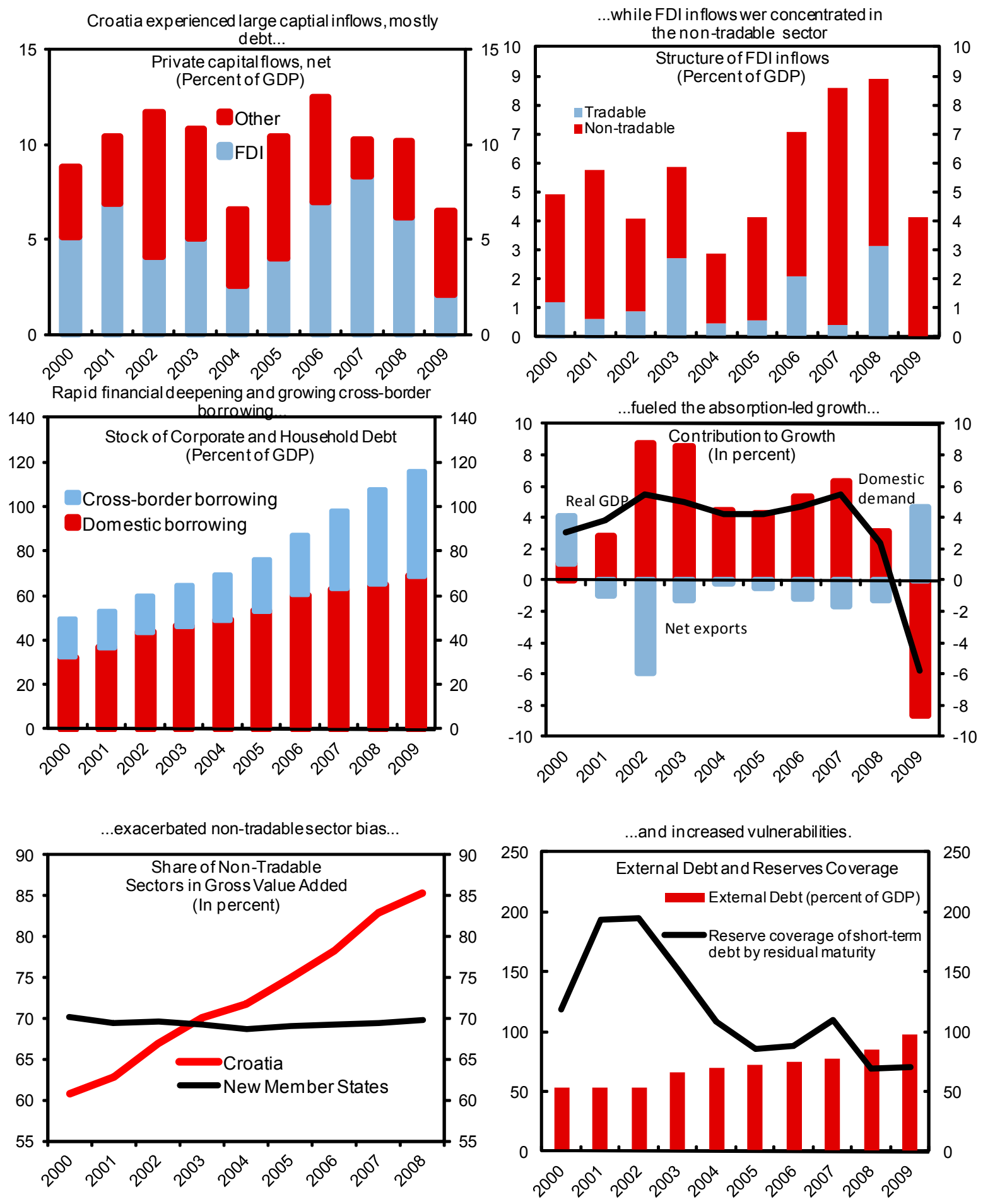

Sources: Croatia National Bank; Haver; and IMF staff calculations. 
Figure 4. Croatia: External Competitiveness Indicators, 2000-09

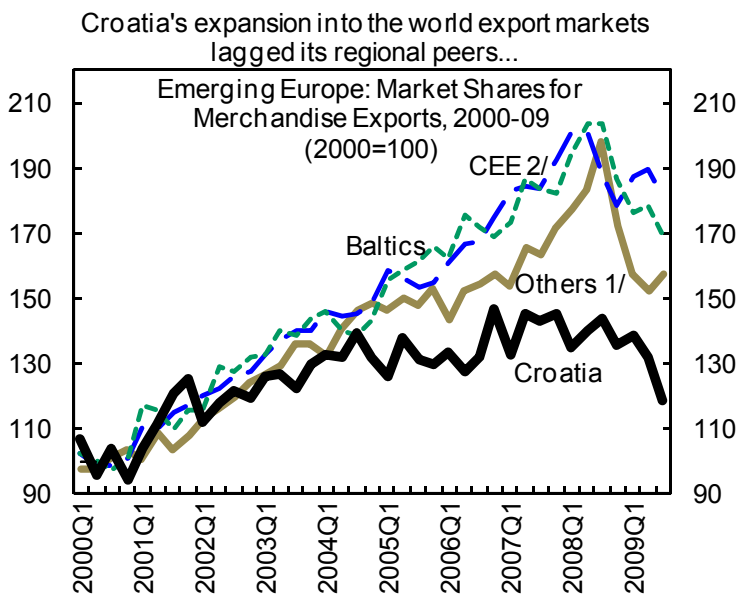

However, exchange rate is likely to be only slightly

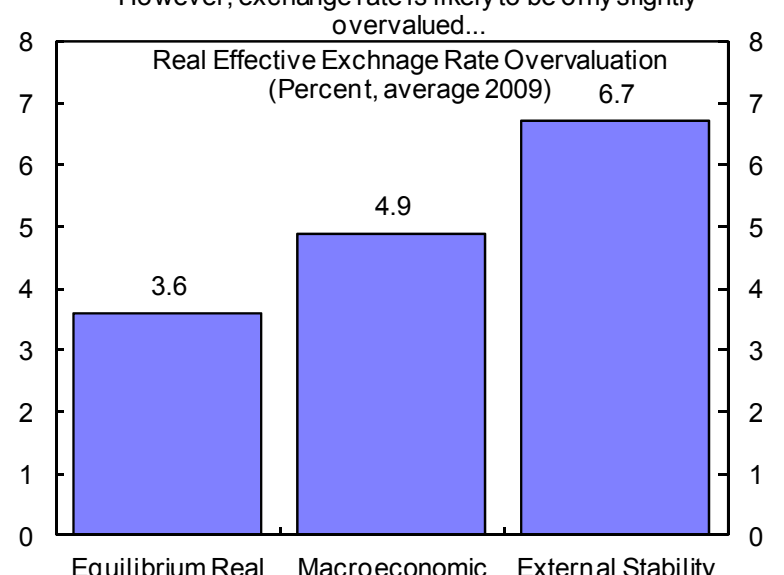

Equilibrium Real Macroeconomic External Stability ExchangeRate Balance Approach Approach 1/ Approach 2/ 1/

Nominal wages ap pear to be somewhat high, even accounting for high productivity...

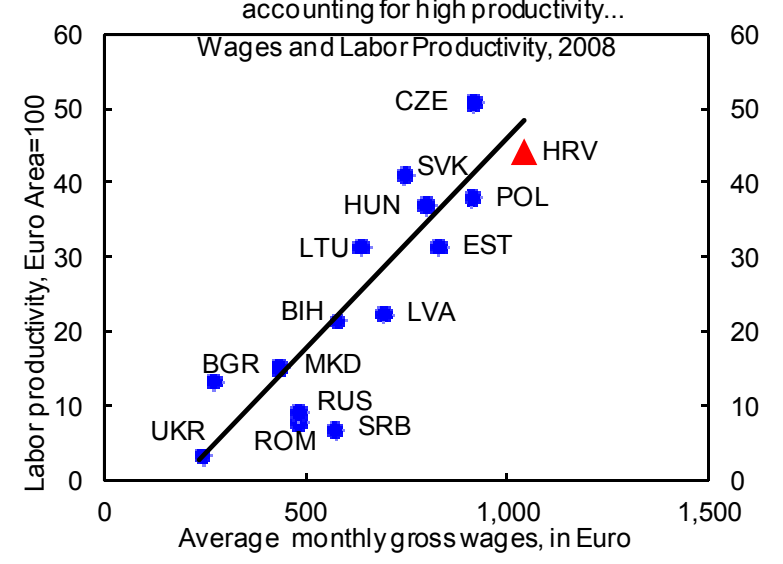

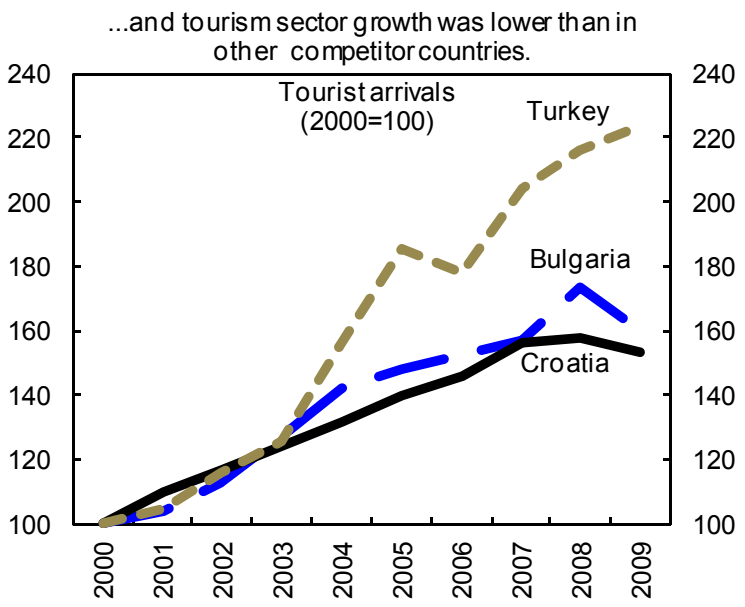

...but un it labor costs grew much faster than in partner

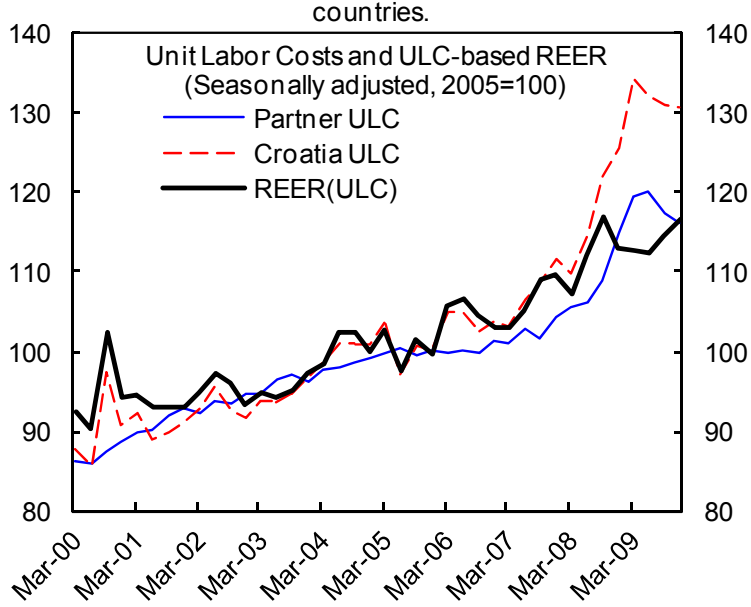

....and relative to the income level.

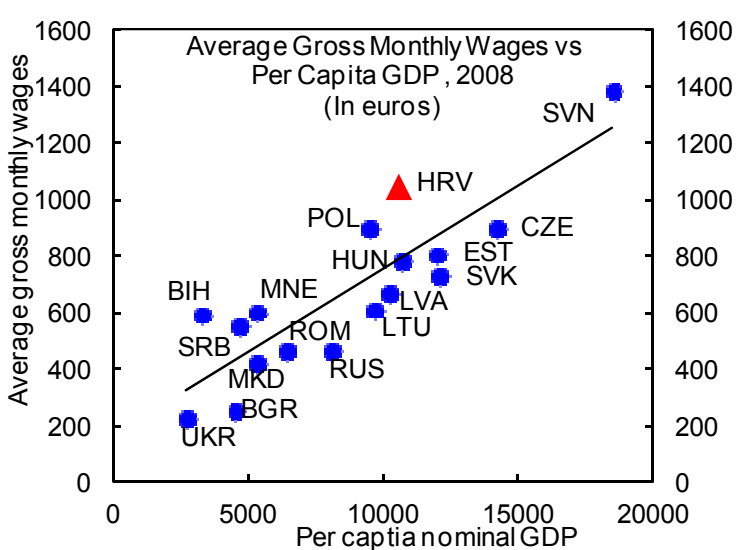

Source: Haver, CNB, IMF staff calculations.

$1 /$ Includes Russia, Turkey, and Ukraine.

2/ Includes Bulgaria, Czech Republic, Hungary, Poland, Romania, Slovak Republic, and Slovenia.

$3 /$ IMF staff estimates are based on CGER methodology and correct for multilateral consistency (see "Methodology for CGER Exchange Rate Assessments, IMF Report No. 06/283).

4/ IMF staff estimates are based on the model reported in Romania's External Stability Risks (Atoyan, 2008, SM/08/168). 
Figure 5. Croatia: Structural Indicators, 2008
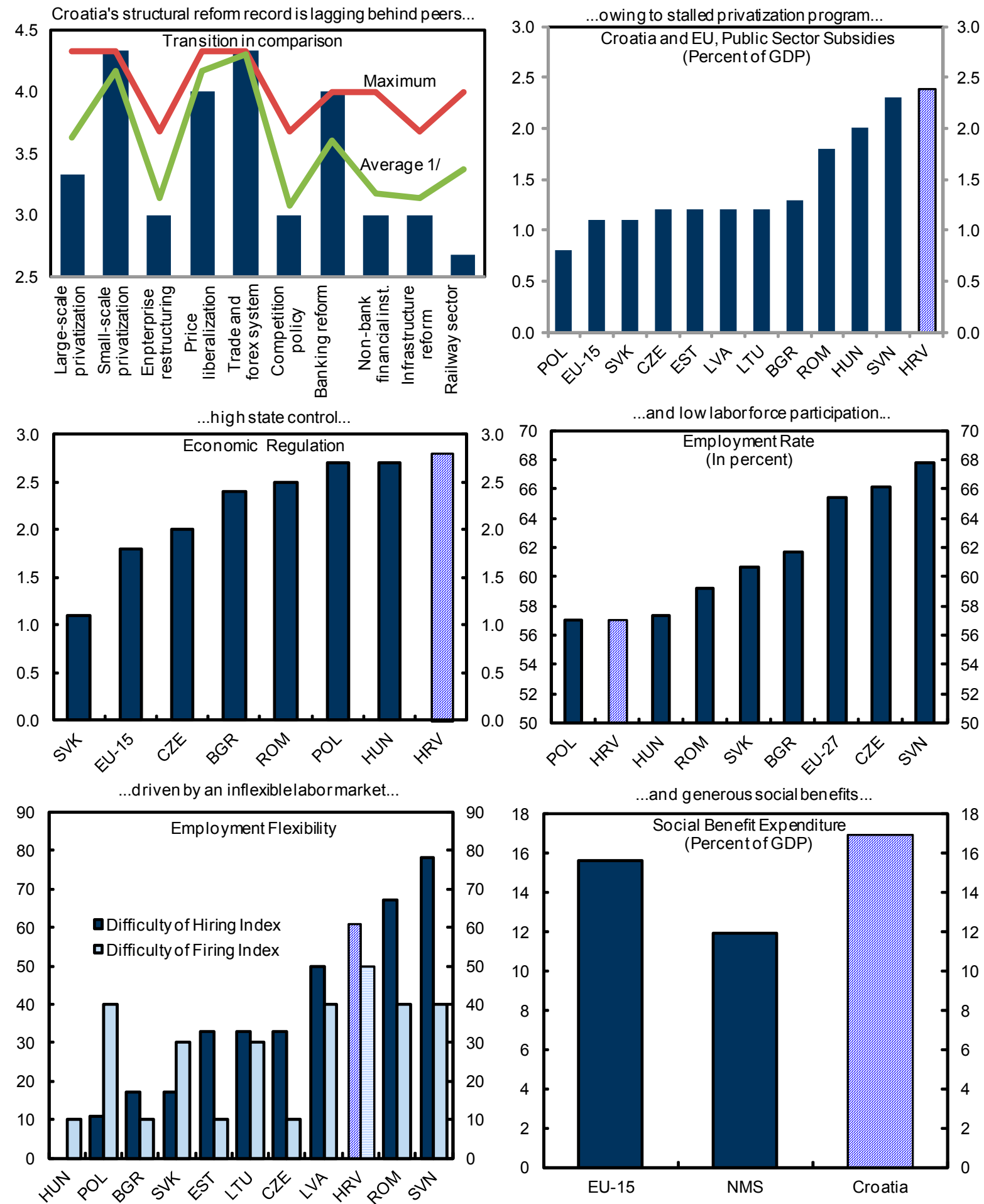

Sources: Eurostat; EBRD; and The World Bank.

1/ Shows average score of the New Member States and Serbia. 
Figure 6. Croatia: Banking Sector Indicators, 2006-10
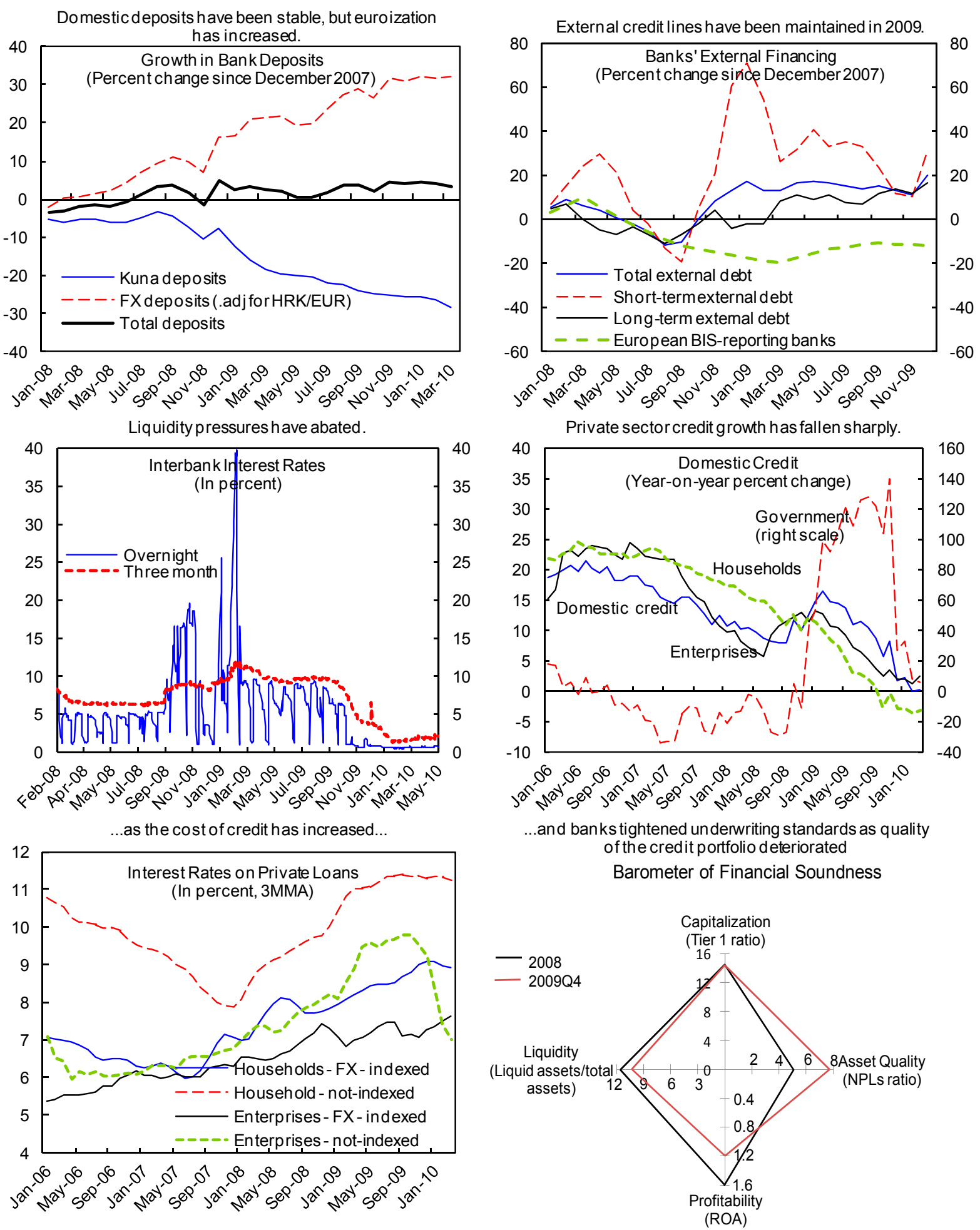

Source: Croatian National Bank, BIS. 
Figure 7. Croatia: Potential Output, 2000-15
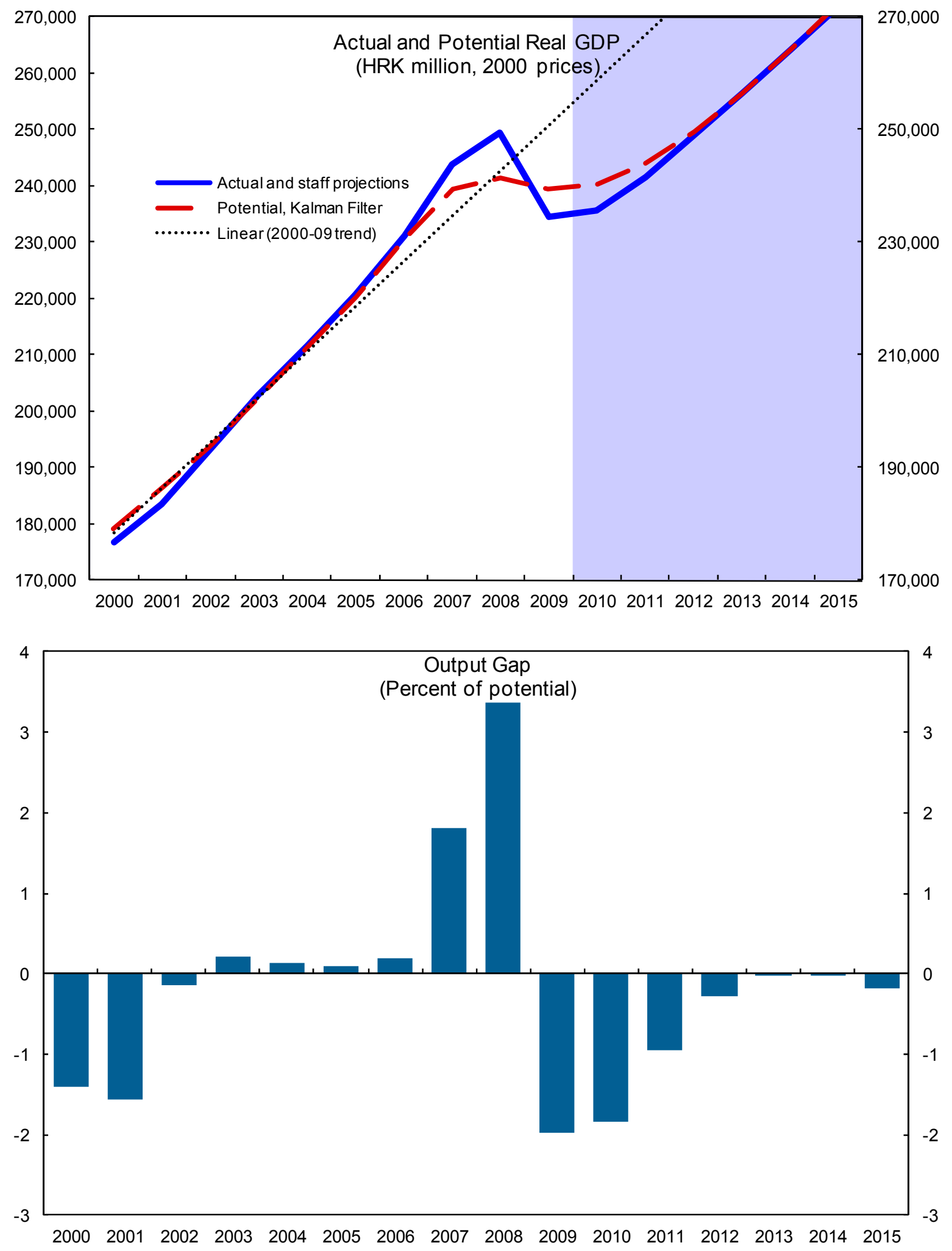

Source: IMF staff estimates. 
Figure 8. Croatia: Fiscal Scenarios, Unchanged Policies and with Adjustment, 2002-15

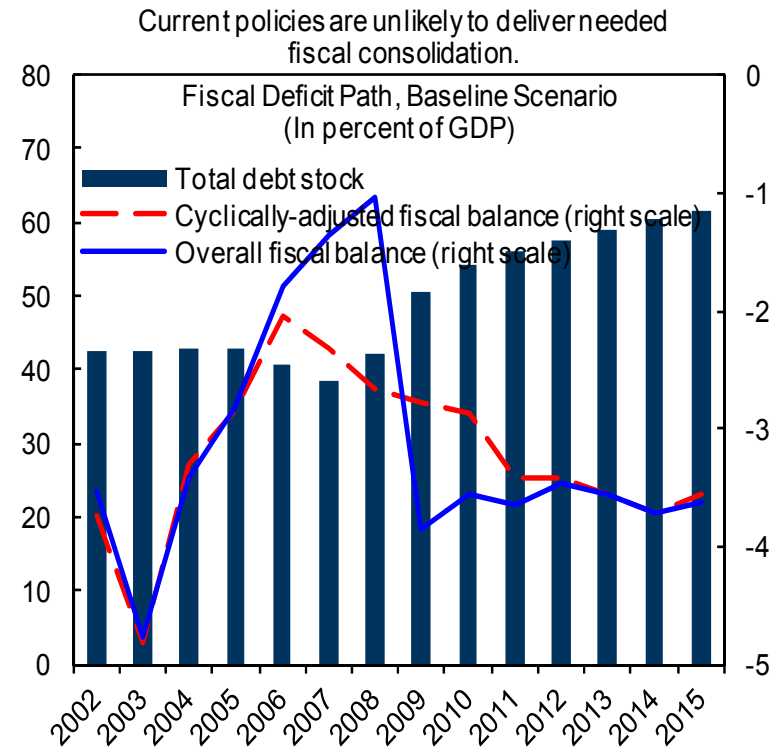

Significant fiscal adjustment is needed over the
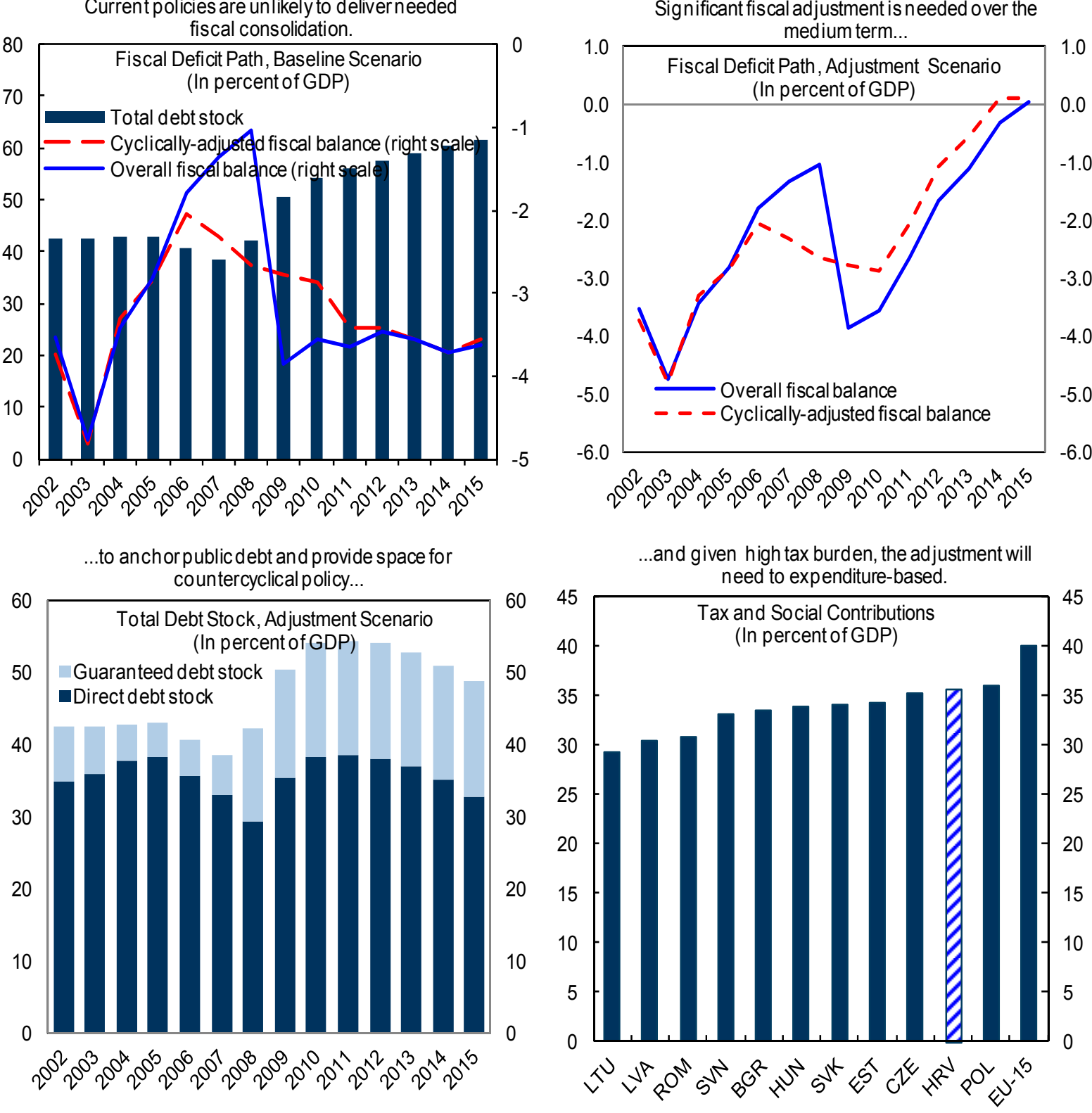

Source: Ministry of Finance; and IMF staff calculations. 
Figure 9. Croatia: Public Debt Sustainability: Bound Tests 1/ (Public debt in percent of GDP)

Baseline and historical scenarios

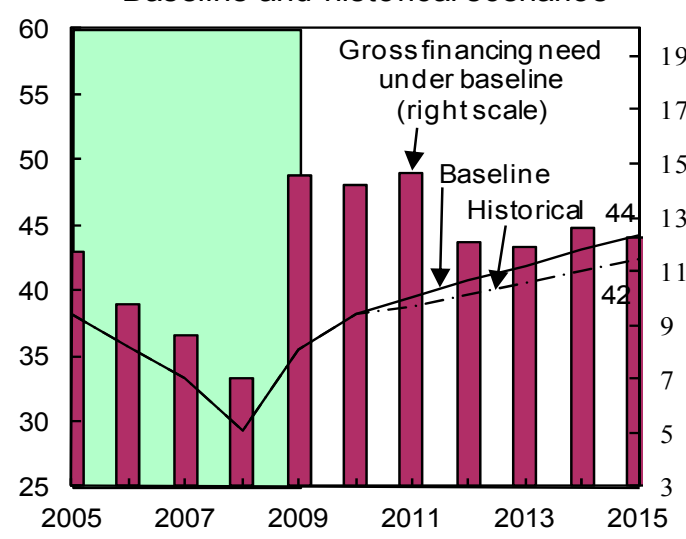

Growth shock (in percent per

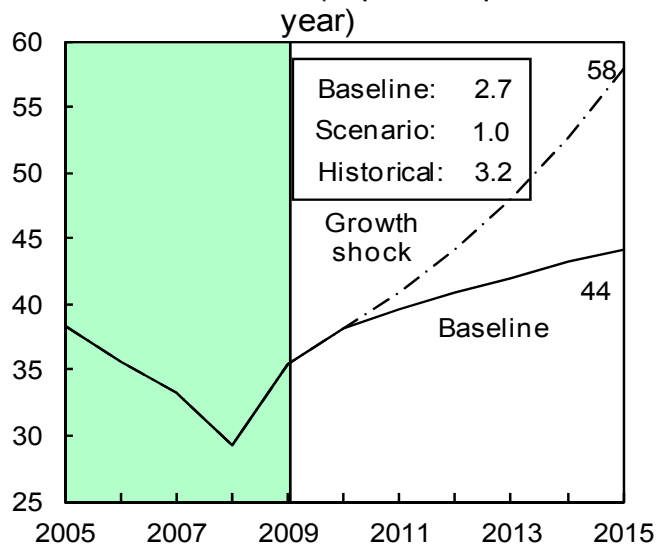

Combined shock 2/

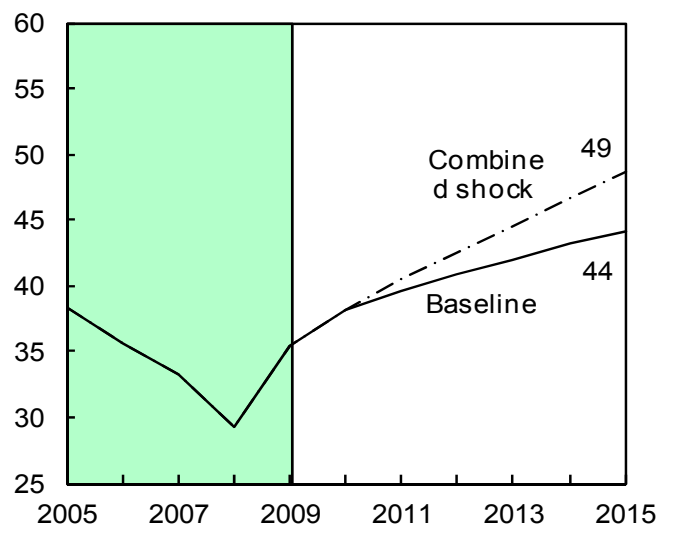

Interest rate shock (in percent)

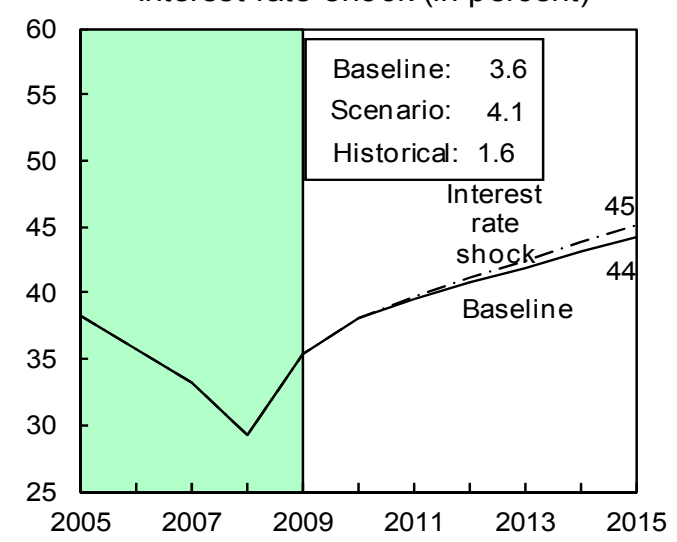

Primary balance shock (in percent of GDP) and no policy change scenario (constant primary

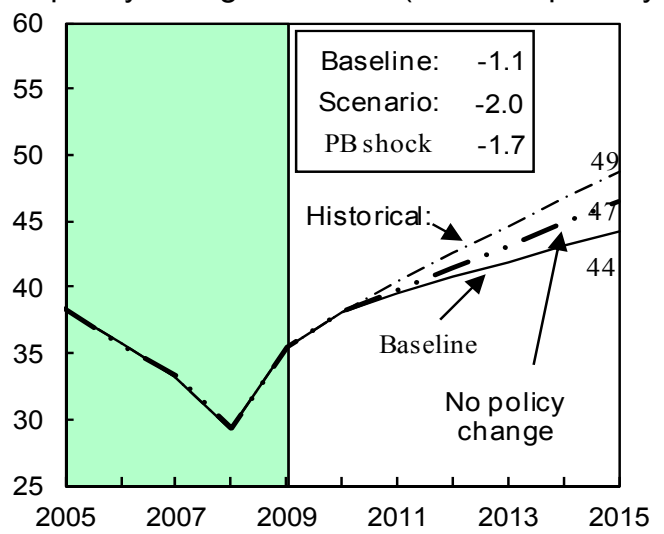

Real depreciation and contingent liabilities shocks $3 /$

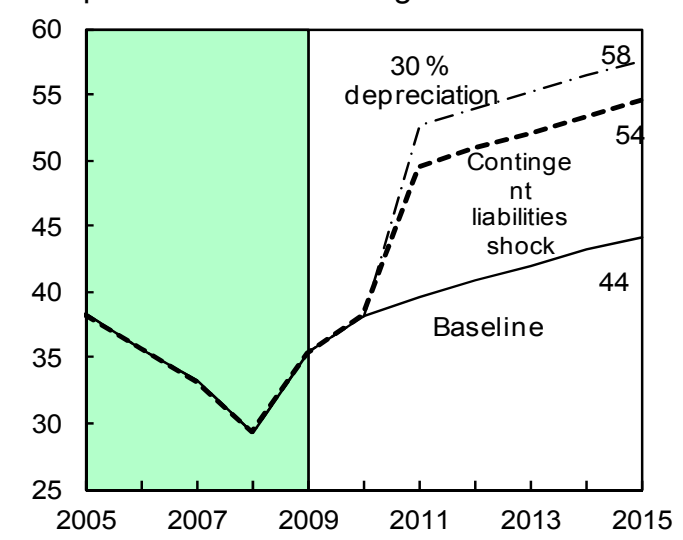

Sources: In temational Monetary Fund, country desk data, and staff estimates.

$1 /$ Shad ed areas rep resent actual data. In dividual shocks are permanent one-half standard deviation shocks.

Figures in the boxes represent average projections for the respective variables in the baseline and scenario being presented. Ten-year historical average for the variable is also shown.

2/ Permanent $1 / 4$ standard deviation shocks ap plied to real interest rate, growth rate, and primary balance.

$3 /$ One-time real depreciation of 30 percent and 10 percent of GDP shock to contingent liabilities occur in 2009 , with real depreciation defined as nominal depreciation (measured by percentage fall in dollar value of local curren cy) minus domestic inflation (based on GDP d eflator). 
Figure 10. Croatia: External Debt Sustainability: Bound Tests 1/ (External debt in percent of GDP)

Baseline and historical scenarios

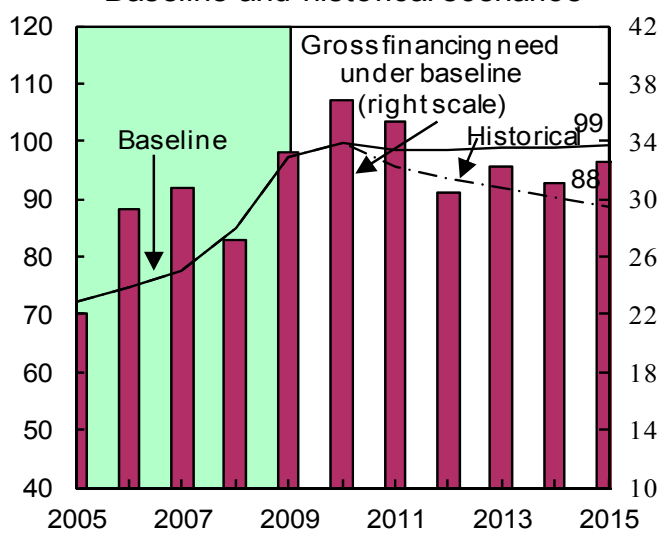

Growth shock (in percent per year)

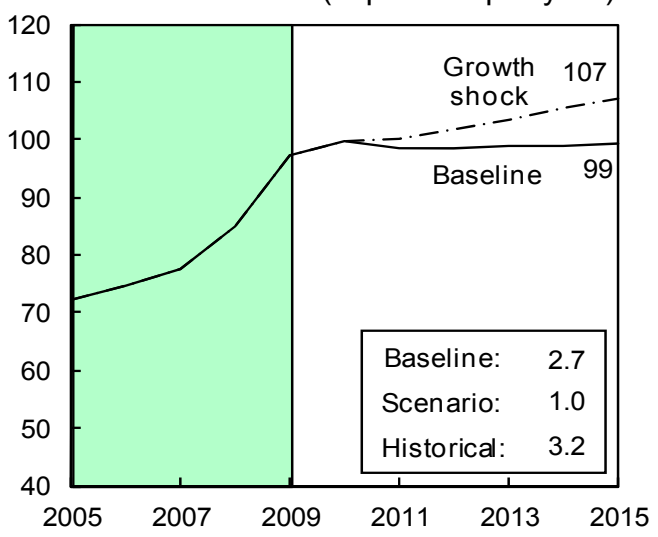

Combined shock 2/

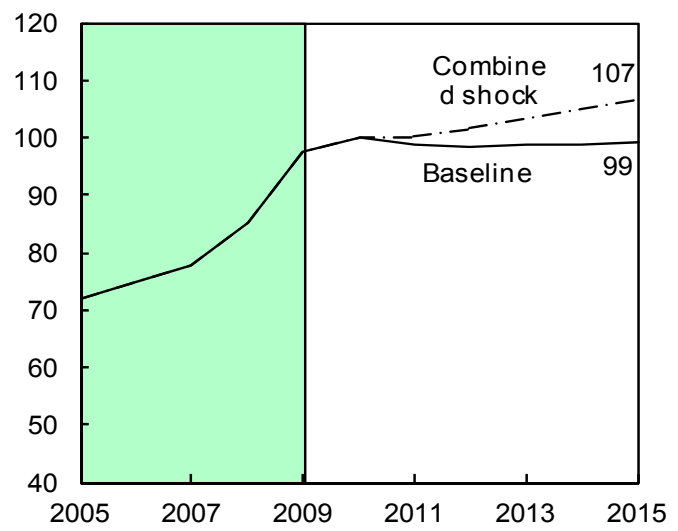

Interest rate shock (in percent)

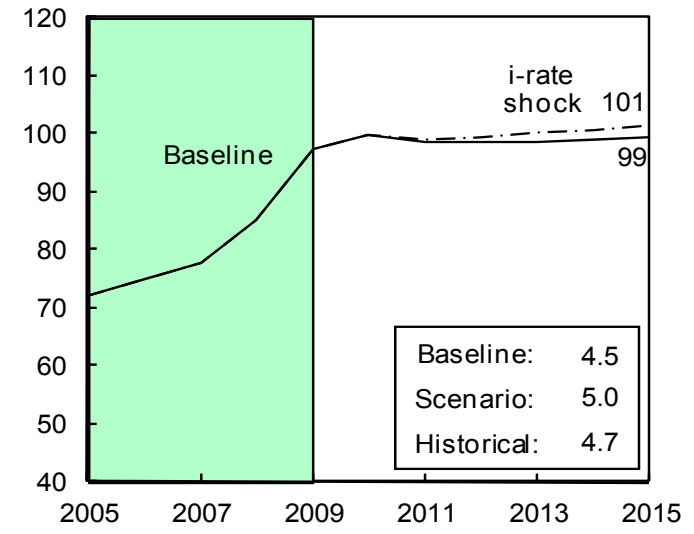

Non-interest current account shock (in percent of GDP)

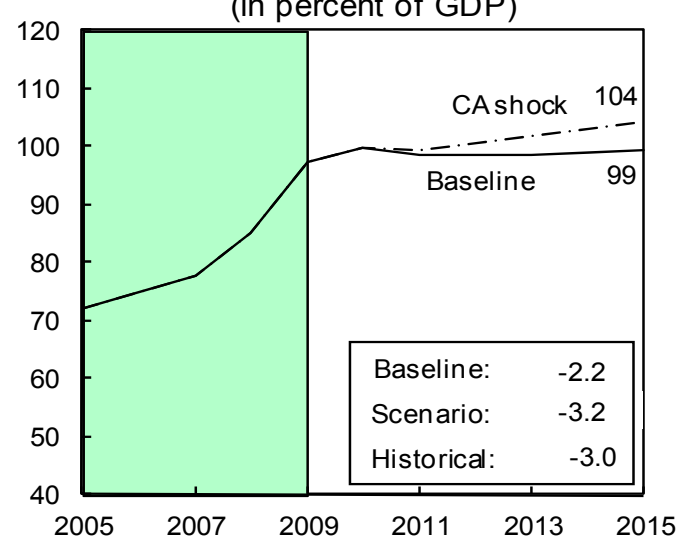

Real depreciation shock $3 /$

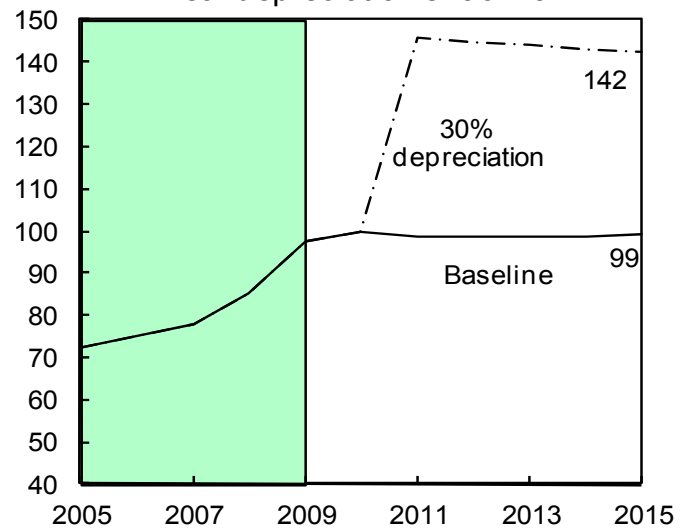

Sources: International Monetary Fund, Country desk data, and staff estimates.

1 / Shaded areas represent actual data. Individual shocks are permanent one-half standard deviation shocks. Figures in the boxes represent average projections for the respective variables in the baseline and scenario being presented. Ten-year historical average for the variable is also shown. 2/Permanent $1 / 4$ standard deviation shocks applied to real interest rate, growth rate, and current account balance.

3/ One-time real depreciation of 30 percent occurs in 2010. 
Table 1. Croatia: Key Macroeconomic Indicators, 2005-11 1/

\begin{tabular}{|c|c|c|c|c|c|c|c|}
\hline & 2005 & 2006 & 2007 & 2008 & 2009 & $\begin{array}{l}2010 \\
\text { Proj. }\end{array}$ & $\begin{array}{l}2011 \\
\text { Proj. }\end{array}$ \\
\hline Output, unemployment, and prices & \multicolumn{7}{|c|}{ (Percent change) } \\
\hline Real GDP & 4.2 & 4.7 & 5.5 & 2.4 & -5.8 & 0.0 & 2.0 \\
\hline Unemployment (labor force survey, in percent) & 12.7 & 11.1 & 9.6 & 8.7 & 9.2 & 9.5 & 9.0 \\
\hline CPI inflation (average) & 3.3 & 3.2 & 2.9 & 6.1 & 2.4 & 2.0 & 2.7 \\
\hline Saving and investment & \multicolumn{7}{|c|}{ (In percent of GDP) } \\
\hline Domestic investment & 28.0 & 29.8 & 30.5 & 32.8 & 28.3 & 30.2 & 30.6 \\
\hline Of which: fixed capital formation & 24.6 & 26.1 & 26.2 & 27.6 & 24.7 & 25.1 & 25.6 \\
\hline Domestic saving & 22.5 & 22.9 & 22.9 & 23.6 & 23.1 & 24.8 & 24.7 \\
\hline Government & 2.3 & 2.9 & 3.8 & 3.2 & 0.0 & -0.6 & -0.6 \\
\hline Nongovernment & 20.2 & 20.0 & 19.1 & 20.4 & 23.1 & 25.4 & 25.3 \\
\hline \multicolumn{8}{|l|}{ Government sector 2/ } \\
\hline General government revenue 2/ & 39.2 & 39.6 & 40.7 & 39.8 & 38.7 & 37.6 & 37.4 \\
\hline General government expenditure 2/ & 42.1 & 41.4 & 42.0 & 40.7 & 41.9 & 41.2 & 41.1 \\
\hline General government balance 2/3/ & -2.8 & -1.8 & -1.2 & -0.9 & -3.2 & -3.6 & -3.7 \\
\hline General government balance (broad definition) 2/3/4/ & -2.8 & -0.8 & -2.4 & -1.3 & -4.1 & -3.8 & -3.9 \\
\hline HBOR balance (net of budget transfers) & -0.1 & -0.2 & -0.5 & -0.1 & -0.6 & -0.6 & -0.6 \\
\hline Cyclically adjusted primary balance $2 / 3 /$ & -0.8 & 0.2 & -0.6 & -1.2 & -1.1 & -0.8 & -1.2 \\
\hline General government debt & 38.4 & 35.8 & 33.2 & 29.3 & 35.4 & 38.2 & 39.6 \\
\hline \multicolumn{8}{|l|}{ Money and credit } \\
\hline Bank credit to the nongovernment sector & 17.4 & 23.1 & 15.0 & 10.6 & -0.6 & $\ldots$ & $\ldots$ \\
\hline Broad money & 10.5 & 18.0 & 18.3 & 4.3 & -0.9 & $\ldots$ & $\ldots$ \\
\hline \multicolumn{8}{|l|}{ Interest rates $5 /$} \\
\hline Average kuna deposit rate (unindexed) & 1.7 & 1.7 & 2.3 & 2.8 & 3.2 & $\ldots$ & $\ldots$ \\
\hline Average kuna credit rate (unindexed) & 11.2 & 9.9 & 9.3 & 10.1 & 11.6 & $\ldots$ & $\ldots$ \\
\hline Average credit rate, foreign currency-indexed loans & 6.7 & 6.3 & 6.3 & 7.5 & 8.1 & $\ldots$ & $\ldots$ \\
\hline \multicolumn{8}{|l|}{ Balance of payments } \\
\hline Current account balance & $-1,976$ & $-2,715$ & $-3,237$ & $-4,371$ & $-2,361$ & $-2,505$ & $-2,888$ \\
\hline (In percent of GDP) & -5.5 & -6.9 & -7.6 & -9.2 & -5.2 & -5.4 & -5.9 \\
\hline Capital and financial account & 3,924 & 5,083 & 4,861 & 5,621 & 3,981 & 3,267 & 2,905 \\
\hline Overall balance & 822 & 1,412 & 722 & -330 & 896 & 262 & -583 \\
\hline \multicolumn{8}{|l|}{ Debt and reserves } \\
\hline Gross official reserves & 7,438 & 8,725 & 9,307 & 8,926 & 10,376 & 10,638 & 10,055 \\
\hline In percent of short-term debt (by residual maturity) & 85 & 88 & 109 & 69 & 71 & 74 & 80 \\
\hline In months of following year's imports of goods and NFS & 4.5 & 4.9 & 4.7 & 6.0 & 6.7 & 6.5 & 5.8 \\
\hline Net international reserves & 5,604 & 6,464 & 7,349 & 7,849 & 9,365 & 9,947 & 9,364 \\
\hline External debt service to exports ratio (in percent) & 27.2 & 37.5 & 37.8 & 34.3 & 50.5 & 38.1 & 38.1 \\
\hline Total external debt (in percent of GDP) & 72.1 & 74.9 & 77.6 & 85.1 & 97.4 & 99.9 & 98.6 \\
\hline Net external debt $6 /$ & 37.7 & 38.7 & 41.1 & 48.6 & 60.8 & 63.3 & 62.0 \\
\hline
\end{tabular}

Sources: Croatian authorities, and Fund staff estimates.

1/ National account data for 1995-2008 were revised in 2009. Under the new ESA95 methodology, revised data include estimates for the "gray economy," imputed dwelling rates, and financial intermediate services indirectly measured (FISIM). Revised nominal GDP figure for 2008 is about 14 percent higher than the previous estimate.

2/ ESA 95 presentation. Operations of HAC, a state-oned road company, were excluded from the coverage of the general government in 2008.

3/ Projections for 2010 include unidentified measures of 1 percent of GDP.

$4 /$ Includes "pensioners' debt" repayments.

$5 /$ Weighted average, all maturities. Foreign currency-indexed loans are indexed mainly to euros.

$6 /$ Net of official reserves and commercial bank foreign assets. 
Table 2. Croatia: Consolidated General Government Finances, 2007-2015 1/

(In percent of GDP; ESA 95 presentation)

\begin{tabular}{|c|c|c|c|c|c|c|c|c|c|c|}
\hline & 2007 & 2008 & $\begin{array}{r}2009 \\
\text { Est. }\end{array}$ & $\begin{array}{l}2010 \\
\text { Proj. }\end{array}$ & $\begin{array}{r}2010 \\
\text { Budget }\end{array}$ & $\begin{array}{l}2011 \\
\text { Proj. }\end{array}$ & $\begin{array}{l}2012 \\
\text { Proj. }\end{array}$ & $\begin{array}{l}2013 \\
\text { Proj. }\end{array}$ & $\begin{array}{l}2014 \\
\text { Proj. }\end{array}$ & $\begin{array}{l}2015 \\
\text { Proj. }\end{array}$ \\
\hline Revenue & 40.7 & 39.8 & 38.7 & 37.6 & 38.5 & 37.4 & 37.6 & 37.8 & 37.9 & 38.0 \\
\hline Taxes & 23.4 & 23.3 & 22.1 & 21.3 & 22.2 & 20.9 & 20.9 & 20.9 & 20.9 & 21.0 \\
\hline Taxes on income, profits, and capital gains & 6.0 & 6.2 & 5.9 & 5.2 & 5.5 & 5.1 & 5.2 & 5.2 & 5.2 & 5.3 \\
\hline Payable by individuals & 3.2 & 3.1 & 3.1 & 2.8 & 3.1 & 2.8 & 2.9 & 2.9 & 2.9 & 2.9 \\
\hline Payable by corporations and other enterprises & 2.8 & 3.1 & 2.8 & 2.4 & 2.4 & 2.3 & 2.3 & 2.3 & 2.3 & 2.3 \\
\hline Taxes on goods and services & 16.4 & 16.0 & 14.9 & 14.8 & 15.1 & 14.7 & 14.7 & 14.7 & 14.7 & 14.7 \\
\hline VAT & 12.0 & 12.1 & 11.1 & 11.1 & 11.4 & 11.1 & 11.1 & 11.1 & 11.1 & 11.2 \\
\hline Excises & 3.9 & 3.5 & 3.3 & 3.1 & 3.2 & 3.1 & 3.1 & 3.1 & 3.1 & 3.1 \\
\hline Taxes on international trade and transactions & 0.5 & 0.6 & 0.5 & 0.4 & 0.4 & 0.4 & 0.4 & 0.4 & 0.3 & 0.3 \\
\hline Other taxes $2 /$ & 0.1 & 0.1 & 0.4 & 0.6 & 0.8 & 0.3 & 0.3 & 0.3 & 0.3 & 0.3 \\
\hline Social security contributions & 11.8 & 11.9 & 12.0 & 11.8 & 11.9 & 11.8 & 11.9 & 11.9 & 12.0 & 11.9 \\
\hline Other revenue and grants & 5.1 & 4.2 & 4.4 & 4.3 & 4.1 & 4.4 & 4.5 & 4.6 & 4.7 & 4.9 \\
\hline Capital revenue & 0.4 & 0.4 & 0.2 & 0.3 & 0.2 & 0.3 & 0.3 & 0.3 & 0.3 & 0.3 \\
\hline Total expenditure & 42.0 & 40.7 & 41.9 & 41.2 & 41.2 & 41.1 & 41.1 & 41.3 & 41.6 & 41.7 \\
\hline Current expenditures & 38.1 & 38.1 & 39.9 & 39.3 & 39.0 & 39.1 & 39.2 & 39.3 & 39.4 & 39.4 \\
\hline Compensation of employees & 9.9 & 9.8 & 10.6 & 10.2 & 10.4 & 10.4 & 10.5 & 10.6 & 10.7 & 10.8 \\
\hline Use of goods and services & 5.0 & 4.8 & 4.6 & 4.7 & 4.6 & 4.7 & 4.6 & 4.6 & 4.5 & 4.5 \\
\hline Interest & 1.8 & 1.5 & 1.7 & 2.1 & 1.9 & 2.2 & 2.4 & 2.5 & 2.8 & 2.8 \\
\hline Subsidies & 2.4 & 2.4 & 2.4 & 2.4 & 2.0 & 2.1 & 2.0 & 1.9 & 1.8 & 1.7 \\
\hline Grants & 0.5 & 0.7 & 0.7 & 0.6 & 0.7 & 0.5 & 0.5 & 0.6 & 0.6 & 0.5 \\
\hline Social benefits & 15.5 & 15.6 & 17.1 & 16.6 & 16.8 & 16.5 & 16.4 & 16.4 & 16.3 & 16.3 \\
\hline Other expense & 2.9 & 3.4 & 2.8 & 2.7 & 2.6 & 2.7 & 2.7 & 2.7 & 2.7 & 2.7 \\
\hline Capital expenditure & 3.9 & 2.6 & 2.0 & 1.9 & 2.2 & 2.0 & 1.9 & 2.0 & 2.1 & 2.3 \\
\hline Payment of called guarantees & 0.1 & 0.1 & 0.6 & & & & & & & \\
\hline Overall balance & -1.3 & -1.0 & -3.9 & -3.6 & -2.7 & -3.7 & -3.5 & -3.6 & -3.7 & -3.6 \\
\hline Repayment of "pensioners' debt" & 1.1 & 0.3 & 0.2 & 0.2 & 0.2 & 0.2 & 0.2 & 0.0 & 0.0 & 0.0 \\
\hline Financing & 2.4 & 1.3 & 4.1 & 3.8 & 3.0 & 3.9 & 3.7 & 3.6 & 3.7 & 3.6 \\
\hline External financing & -0.1 & -0.1 & 1.5 & 0.9 & 0.9 & -1.1 & 1.2 & 1.1 & 0.2 & 0.1 \\
\hline Disbursements & -0.1 & 2.1 & 3.6 & 3.0 & 3.0 & 2.1 & 1.9 & 1.7 & 1.5 & 1.3 \\
\hline Amortization & 0.0 & -2.1 & -2.2 & -2.0 & -2.0 & -3.2 & -0.7 & -0.5 & -1.3 & -1.2 \\
\hline Domestic financing & 1.5 & 1.0 & 2.6 & 2.7 & 1.9 & 4.5 & 2.4 & 2.4 & 3.5 & 3.4 \\
\hline \multicolumn{11}{|l|}{ Memorandum items: } \\
\hline Primary balance & 0.4 & 0.4 & -2.2 & -1.5 & -0.9 & -1.4 & -1.1 & -1.0 & -1.0 & -0.8 \\
\hline Cyclically adjusted balance & -2.3 & -2.7 & -2.8 & -2.9 & $\ldots$ & -3.4 & -3.4 & -3.5 & -3.7 & -3.6 \\
\hline HBOR balance (net of budget transfers) $3 /$ & -0.5 & -0.1 & -0.6 & -0.6 & $\ldots$ & -0.6 & -0.6 & -0.6 & -0.6 & -0.6 \\
\hline HAC balance $3 /$ & -0.5 & -0.9 & -0.7 & -0.7 & $\ldots$ & -0.7 & -0.7 & -0.7 & -0.7 & -0.7 \\
\hline Broader measure of fiscal balance $4 /$ & -3.3 & -2.2 & -4.8 & -5.1 & $\ldots$ & -5.2 & -5.0 & -4.9 & -5.1 & -5.0 \\
\hline General government debt & 33.2 & 29.3 & 35.4 & 38.2 & $\ldots$ & 39.6 & 40.8 & 42.0 & 43.2 & 44.2 \\
\hline General government guarantees & 8.6 & 13.0 & 15.0 & 15.9 & $\ldots$ & 16.5 & 16.8 & 17.1 & 17.2 & 17.3 \\
\hline
\end{tabular}

Sources: Ministry of Finance; and Fund staff estimates.

1/ Operations of HAC, a road fund, was excluded from the coverage of the general government in 2008.

2/ For 2009-2010, includes revenue from the "solidarity tax."

3/ The balances of HBOR and HAC for 2010-15 are assumed to remain at their 2009 levels.

4 / Includes repayments of "pensioners' debt", and the balances of HBOR and HAC (net of budget transfers). 
Table 3. Croatia: Balance of Payments, 2007-15

(In millions of euros, unless otherwise indicated)

\begin{tabular}{|c|c|c|c|c|c|c|c|c|c|}
\hline & 2007 & 2008 & 2009 & $\begin{array}{l}2010 \\
\text { Proj. }\end{array}$ & $\begin{array}{l}2011 \\
\text { Proj. }\end{array}$ & $\begin{array}{l}2012 \\
\text { Proj. }\end{array}$ & $\begin{array}{l}2013 \\
\text { Proj. }\end{array}$ & $\begin{array}{l}2014 \\
\text { Proj. }\end{array}$ & $\begin{array}{l}2015 \\
\text { Proj. }\end{array}$ \\
\hline Current account & $-3,237$ & $-4,371$ & $-2,361$ & $-2,505$ & $-2,888$ & $-3,031$ & $-3,529$ & $-3,794$ & $-4,287$ \\
\hline Merchandise trade balance & $-9,434$ & $-10,794$ & $-7,398$ & $-7,475$ & $-7,881$ & $-8,314$ & $-8,955$ & $-9,637$ & $-10,546$ \\
\hline Exports f.o.b. & 9,193 & 9,814 & 7,691 & 8,449 & 8,976 & 9,550 & 10,199 & 10,897 & 11,593 \\
\hline Imports f.o.b. & $-18,626$ & $-20,608$ & $-15,089$ & $-15,924$ & $-16,858$ & $-17,864$ & $-19,153$ & $-20,534$ & $-22,139$ \\
\hline Services and income & 5,154 & 5,387 & 4,002 & 3,881 & 3,826 & 4,033 & 4,090 & 4,417 & 4,735 \\
\hline Transportation & 488 & 509 & 255 & 302 & 322 & 345 & 366 & 389 & 404 \\
\hline Travel & 6,035 & 6,694 & 5,649 & 5,635 & 5,959 & 6,358 & 6,780 & 7,059 & 7,665 \\
\hline Other services & -257 & -245 & -237 & -171 & -176 & -181 & -200 & -220 & -260 \\
\hline Compensation of employees & 494 & 564 & 587 & 438 & 464 & 494 & 527 & 552 & 596 \\
\hline Interest and investment income & $-1,606$ & $-2,135$ & $-2,251$ & $-2,323$ & $-2,743$ & $-2,984$ & $-3,383$ & $-3,364$ & $-3,669$ \\
\hline Current transfers & 1,043 & 1,036 & 1,035 & 1,089 & 1,167 & 1,250 & 1,336 & 1,427 & 1,523 \\
\hline Capital and financial account & 4,861 & 5,621 & 3,981 & 3,267 & 2,905 & 4,053 & 4,667 & 5,008 & 5,353 \\
\hline Capital account $1 /$ & 35 & 15 & 39 & 35 & 35 & 35 & 35 & 36 & 37 \\
\hline Financial account $1 /$ & 4,827 & 5,606 & 3,941 & 3,232 & 2,870 & 4,018 & 4,632 & 4,972 & 5,316 \\
\hline Direct investment & 3,483 & 3,226 & 989 & 1,681 & 1,578 & 1,772 & 1,937 & 2,161 & 2,307 \\
\hline Portfolio investment & -3 & -627 & 275 & 1,155 & 804 & 770 & 462 & 991 & 755 \\
\hline Medium- and long-term loans & 2,718 & 2,900 & 1,042 & 625 & 430 & 1,299 & 2,259 & 2,348 & 2,781 \\
\hline Assets & 3 & -64 & -8 & 0 & 0 & 0 & 0 & 0 & 0 \\
\hline Liabilities & 2,715 & 2,965 & 1,049 & 625 & 430 & 1,299 & 2,259 & 2,348 & 2,781 \\
\hline Disbursements & 7,700 & 7,640 & 6,330 & 9,622 & 8,632 & 8,392 & 10,790 & 10,383 & 11,743 \\
\hline Amortization & $-4,985$ & $-4,676$ & $-5,280$ & $-8,998$ & $-8,202$ & $-7,093$ & $-8,531$ & $-8,035$ & $-8,963$ \\
\hline Currency and deposits & $-1,756$ & -497 & 1,660 & -300 & -18 & -39 & -247 & -761 & -770 \\
\hline Short-term capital flows (net) & 168 & 696 & -31 & 60 & 62 & 157 & 165 & 173 & 182 \\
\hline Trade credits & 214 & -95 & 5 & 11 & 14 & 58 & 56 & 60 & 61 \\
\hline Net errors and omissions $1 /$ & -903 & $-1,580$ & -698 & -500 & -600 & -700 & -800 & -900 & $-1,000$ \\
\hline Overall balance & 722 & -330 & 896 & 262 & -583 & 323 & 338 & 315 & 66 \\
\hline Financing & -722 & 330 & -896 & -262 & 583 & -323 & -338 & -315 & -66 \\
\hline Gross reserves (-= increase) & -722 & 330 & -896 & -262 & 583 & -323 & -338 & -315 & -66 \\
\hline IMF (net purchases) & 0 & 0 & 0 & 0 & 0 & 0 & 0 & 0 & 0 \\
\hline Exceptional financing & 0 & 0 & 0 & 0 & 0 & 0 & 0 & 0 & 0 \\
\hline \multicolumn{10}{|l|}{ Memorandum items: } \\
\hline Current account (in percent of GDP) & -7.6 & -9.2 & -5.2 & -5.4 & -5.9 & -5.9 & -6.5 & -6.6 & -7.0 \\
\hline Export volume growth (excl. ships) & 7.2 & 1.3 & -19.2 & 2.9 & 3.6 & 5.2 & 5.7 & 5.6 & 5.3 \\
\hline Import volume growth & 9.0 & 4.3 & -20.0 & -2.4 & 3.0 & 4.6 & 5.9 & 5.9 & 6.0 \\
\hline Gross official reserves & 9,307 & 8,926 & 10,376 & 10,638 & 10,055 & 10,378 & 10,716 & 11,030 & 11,096 \\
\hline in months of following year's imports of goods and NFS & 4.7 & 6.0 & 6.7 & 6.5 & 5.8 & 5.6 & 5.4 & 5.1 & 5.1 \\
\hline Outstanding debt & 33,253 & 40,316 & 44,591 & 46,442 & 48,034 & 50,680 & 53,876 & 57,287 & 60,996 \\
\hline External debt to GDP ratio & 77.6 & 85.1 & 97.4 & 99.9 & 98.6 & 98.5 & 98.7 & 98.9 & 99.3 \\
\hline External debt in percent of exports of goods and NFS & 181.8 & 202.5 & 276.5 & 274.7 & 268.0 & 265.6 & 264.6 & 265.6 & 264.1 \\
\hline Short-term debt by residual maturity (in percent of GIR) & 91.4 & 143.9 & 141.1 & 134.5 & 125.2 & 135.2 & 132.5 & 130.3 & 131.2 \\
\hline External debt service & $-6,909$ & $-6,801$ & $-8,192$ & $-11,512$ & $-11,507$ & $-9,837$ & $-11,337$ & $-11,241$ & $-12,712$ \\
\hline GDP (millions of euros) & 42,831 & 47,364 & 45,787 & 46,502 & 48,737 & 51,454 & 54,587 & 57,912 & 61,438 \\
\hline GDP (millions of kuna) & 314,223 & 342,158 & 333,063 & 339,754 & 356,079 & 375,931 & 398,825 & 423,113 & 448,881 \\
\hline
\end{tabular}

Sources: Croatian National Bank; and Fund staff estimates.

1/Errors and omissions are explicitly projected to reflect persistent unrecorded capital oufflows. 
Table 4. External Financing Requirement, 2007-11

(In millions of euros, unless otherwise indicated)

\begin{tabular}{|c|c|c|c|c|c|}
\hline & 2007 & 2008 & 2009 & 2010 & 2011 \\
\hline Financing requirements & $-13,688$ & $-13,013$ & $-15,787$ & $-18,992$ & $-18,808$ \\
\hline Current account deficit & $-3,237$ & $-4,371$ & $-2,361$ & $-2,505$ & $-3,031$ \\
\hline Amortization on MLT debt (exist.+new) & $-5,698$ & $-5,412$ & $-7,565$ & $-11,058$ & $-9,881$ \\
\hline Public & -940 & -776 & $-1,247$ & $-1,017$ & -686 \\
\hline Private & -4758 & -4636 & -6318 & -10041 & -9195 \\
\hline Banks 1/ & $-1,879$ & -914 & $-2,182$ & $-2,104$ & $-3,550$ \\
\hline Non-banks 2/ & $-2,879$ & $-3,722$ & $-4,136$ & $-7,937$ & $-5,645$ \\
\hline Repayment of short-term debt (incl. ST deposits \& ST trade credit) & $-4,753$ & $-3,230$ & $-5,861$ & $-5,429$ & $-5,897$ \\
\hline Public & 0 & -1 & -33 & -1 & 0 \\
\hline Private & $-4,753$ & $-3,229$ & $-5,829$ & $-5,428$ & $-5,897$ \\
\hline Banks & $-2,885$ & $-2,361$ & $-3,791$ & $-3,172$ & $-3,579$ \\
\hline Non-banks & $-1,869$ & -867 & $-2,037$ & $-2,256$ & $-2,318$ \\
\hline Financing sources & 13,688 & 13,013 & 15,787 & 18,992 & 18,808 \\
\hline Capital transfers & 35 & 15 & 39 & 35 & 35 \\
\hline FDI, net & 3,483 & 3,226 & 989 & 1,681 & 1,772 \\
\hline Disbursements on bonds and MLT loans & 8,673 & 8,144 & 11,081 & 12,854 & 12,232 \\
\hline Public & 824 & 633 & 2,165 & 2,195 & 1,556 \\
\hline Private & 7,848 & 7,511 & 8,916 & 10,659 & 10,676 \\
\hline Banks & 1,249 & 636 & 3,481 & 2,239 & 4,703 \\
\hline Non-banks & 6,599 & 6,875 & 5,435 & 8,420 & 5,973 \\
\hline Short-term financing & 4,871 & 4,848 & 5,287 & 5,483 & 6,192 \\
\hline Public & 0 & 33 & 0 & 0 & 0 \\
\hline Private & 4,871 & 4,815 & 5,287 & 5,483 & 6,192 \\
\hline Banks 1/ & 2,244 & 3,634 & 3,059 & 3,188 & 3,758 \\
\hline Non-banks 2/ & 2,627 & 1,181 & 2,228 & 2,295 & 2,434 \\
\hline Other flows & $-2,652$ & $-3,552$ & -713 & -799 & $-1,100$ \\
\hline Gross International Reserves (- = increase) & -722 & 330 & -896 & -262 & -323 \\
\hline Financing gap & 0 & 0 & 0 & 0 & 0 \\
\hline \multicolumn{6}{|l|}{ Memorandum items } \\
\hline Current account deficit (in \% of GDP) & -7.6 & -9.2 & -5.2 & -5.4 & -5.9 \\
\hline Gross official reserves (EUR bn) & 9,307 & 8,926 & 10,376 & 10,638 & 10,378 \\
\hline in months of imports & 4.7 & 6.0 & 6.7 & 6.5 & 5.6 \\
\hline in percent of ST debt by residual maturity & 109 & 69 & 71 & 74 & 74 \\
\hline GDP (EUR bn) & 42,831 & 47,364 & 45,787 & 46,502 & 51,454 \\
\hline
\end{tabular}

Source: CNB, staff projections.

$1 /$ Includes longer-term currency and deposits.

2/ Includes longer-term trade credits. 
Table 5. Croatia: Medium-Term, 2005-15 1/

\begin{tabular}{|c|c|c|c|c|c|c|c|c|c|c|c|}
\hline & 2005 & 2006 & 2007 & 2008 & 2009 & 2010 & 2011 & 2012 & 2013 & 2014 & 2015 \\
\hline & & & & & & Proj. & Proj. & Proj. & Proj. & Proj. & Proj. \\
\hline Real sector & \multicolumn{11}{|c|}{ (Percent change) } \\
\hline Real GDP 2/ & 4.2 & 4.7 & 5.5 & 2.4 & -5.8 & 0.0 & 2.0 & 2.5 & 3.0 & 3.0 & 3.0 \\
\hline Consumption, total & 3.6 & 3.2 & 5.6 & 1.1 & -6.5 & -2.7 & 1.4 & 1.9 & 2.7 & 2.7 & 2.7 \\
\hline Of which: private & 4.4 & 3.5 & 6.2 & 0.8 & -8.5 & -3.0 & 1.0 & 1.5 & 2.5 & 2.5 & 2.5 \\
\hline Gross fixed capital formation, total & 4.9 & 10.9 & 6.5 & 8.2 & -11.8 & 1.7 & 4.3 & 4.5 & 5.9 & 5.8 & 5.7 \\
\hline Of which: private & 7.3 & 13.7 & 4.7 & 15.3 & -11.0 & 2.7 & 4.0 & 5.0 & 5.5 & 5.5 & 5.5 \\
\hline CPI inflation (average) & 3.3 & 3.2 & 2.9 & 6.1 & 2.4 & 2.0 & 2.7 & 2.8 & 3.0 & 3.0 & 3.0 \\
\hline Saving and investment & \multicolumn{11}{|c|}{ (In percent of GDP) } \\
\hline Domestic investment & 28.0 & 29.8 & 30.5 & 32.8 & 28.3 & 30.2 & 30.6 & 31.0 & 31.4 & 32.1 & 32.6 \\
\hline Of which: fixed capital formation & 24.6 & 26.1 & 26.2 & 27.6 & 24.7 & 25.1 & 25.6 & 26.2 & 27.0 & 27.7 & 28.4 \\
\hline Domestic saving & 22.5 & 22.9 & 22.9 & 23.6 & 23.1 & 24.8 & 24.7 & 24.8 & 24.9 & 25.5 & 25.6 \\
\hline Government & 2.3 & 2.9 & 3.8 & 3.2 & 0.0 & -0.6 & -0.6 & -0.5 & -0.4 & -0.5 & -0.2 \\
\hline Nongovernment & 20.2 & 20.0 & 19.1 & 20.4 & 23.1 & 25.4 & 25.3 & 25.2 & 25.3 & 26.0 & 25.8 \\
\hline \multicolumn{12}{|l|}{ General government finances $3 /$} \\
\hline Revenue & 39.2 & 39.6 & 40.7 & 39.8 & 38.7 & 37.6 & 37.4 & 37.6 & 37.8 & 37.9 & 38.0 \\
\hline Expenditure 4/ & 42.1 & 41.4 & 42.0 & 40.7 & 41.9 & 41.2 & 41.1 & 41.1 & 41.3 & 41.6 & 41.7 \\
\hline Balance 4/ & -2.8 & -1.8 & -1.2 & -0.9 & -3.2 & -3.6 & -3.7 & -3.5 & -3.6 & -3.7 & -3.6 \\
\hline Government debt & 38.4 & 35.8 & 33.2 & 29.3 & 35.4 & 38.2 & 39.6 & 40.8 & 42.0 & 43.2 & 44.2 \\
\hline \multicolumn{12}{|l|}{ Balance of payments } \\
\hline Current account balance & -5.5 & -6.9 & -7.6 & -9.2 & -5.2 & -5.4 & -5.9 & -5.9 & -6.5 & -6.6 & -7.0 \\
\hline Exports f.o.b. & 20.2 & 21.6 & 21.5 & 20.7 & 16.8 & 18.2 & 18.4 & 18.6 & 18.7 & 18.8 & 18.9 \\
\hline Imports f.o.b. & -41.3 & -43.0 & -43.5 & -43.5 & -33.0 & -34.2 & -34.6 & -34.7 & -35.1 & -35.5 & -36.0 \\
\hline Capital and financial account & 11.0 & 13.0 & 11.3 & 11.9 & 8.7 & 7.0 & 6.0 & 7.9 & 8.5 & 8.6 & 8.7 \\
\hline Of which: FDI & 3.6 & 6.5 & 8.1 & 6.8 & 2.2 & 3.6 & 3.2 & 3.4 & 3.5 & 3.7 & 3.8 \\
\hline Gross external debt & 72.1 & 74.9 & 77.6 & 85.1 & 97.4 & 99.9 & 98.6 & 98.5 & 98.7 & 98.9 & 99.3 \\
\hline Net external debt & 37.7 & 38.7 & 41.1 & 48.6 & 60.8 & 63.3 & 62.0 & 62.0 & 62.2 & 62.4 & 62.7 \\
\hline \multicolumn{12}{|l|}{ Memorandum items: } \\
\hline Nominal GDP (in millions of kuna) & 264,367 & 286,341 & 314,223 & 342,158 & 333,063 & 339,754 & 356,079 & 375,931 & 398,825 & 423,113 & 448,881 \\
\hline Nominal GDP (in millions of euros) & 35,723 & 39,103 & 42,831 & 47,364 & 45,787 & 46,502 & 48,737 & 51,454 & 54,587 & 57,912 & 61,438 \\
\hline
\end{tabular}

Sources: Central Statistics Bureau; Croatian National Bank; Ministry of Finance; and Fund staff estimates.

1/ National account statistics for 1995-2008 were revised in 2009. Under the new ESA95 methodology, revised data include estimates for the "gray economy," imputed dwelling rates, and financial intermediate services indirectly measured (FISIM). On average, revised nominal GDP figures are 15.6 percent higher than the previous estimates.

2/ Assumes an increase in total factor productivity and potential growth as EU accession approaches.

3/ ESA 95 presentation.

4/ Excludes repayments of "pensioners' debt." 
Table 6. Croatia: Monetary Accounts, 2008-10

(End-period; in millions of kuna unless otherwise stated)

\begin{tabular}{|c|c|c|c|c|c|c|c|c|c|c|c|c|}
\hline & 2008 & $\begin{array}{r}2009 \\
Q 1\end{array}$ & $\begin{array}{r}2009 \\
Q 2\end{array}$ & $\begin{array}{r}2009 \\
\text { Q3 }\end{array}$ & $\begin{array}{r}2009 \\
Q 4\end{array}$ & $\begin{array}{r}2010 \\
\text { Q1 }\end{array}$ & 2008 & $\begin{array}{r}2009 \\
\text { Q1 }\end{array}$ & $\begin{array}{r}2009 \\
\text { Q2 }\end{array}$ & $\begin{array}{r}2009 \\
\text { Q3 }\end{array}$ & $\begin{array}{r}2009 \\
Q 4\end{array}$ & $\begin{array}{r}2010 \\
\text { Q1 }\end{array}$ \\
\hline Monetary Survey & & & & & & & \multicolumn{6}{|c|}{ (Change in percent) } \\
\hline $\begin{array}{l}\text { Net Foreign Assets } \\
\text { (In millions of euros) }\end{array}$ & $\begin{array}{r}41,739 \\
5,577\end{array}$ & $\begin{array}{r}26,544 \\
3,559\end{array}$ & $\begin{array}{r}30,116 \\
4,130\end{array}$ & $\begin{array}{r}39,369 \\
5,402\end{array}$ & $\begin{array}{r}45,011 \\
6,161\end{array}$ & $\begin{array}{r}37,752 \\
5,201\end{array}$ & $\begin{array}{l}-15.6 \\
-17.4\end{array}$ & $\begin{array}{l}-39.0 \\
-40.7\end{array}$ & $\begin{array}{l}-33.6 \\
-34.0\end{array}$ & $\begin{array}{l}-28.1 \\
-29.9\end{array}$ & $\begin{array}{r}7.8 \\
10.5\end{array}$ & $\begin{array}{l}42.2 \\
46.1\end{array}$ \\
\hline $\begin{array}{l}\text { Croatian National Bank } \\
\text { (In millions of euros) }\end{array}$ & $\begin{array}{r}66,789 \\
8,924\end{array}$ & $\begin{array}{r}66,128 \\
8,868\end{array}$ & $\begin{array}{r}66,277 \\
9,089\end{array}$ & $\begin{array}{r}67,902 \\
9,317\end{array}$ & $\begin{array}{l}75,800 \\
10,375\end{array}$ & $\begin{array}{l}72,644 \\
10,007\end{array}$ & $\begin{array}{l}-2.0 \\
-4.1\end{array}$ & $\begin{array}{l}-7.4 \\
-9.9\end{array}$ & $\begin{array}{l}-8.0 \\
-8.6\end{array}$ & $\begin{array}{l}-2.6 \\
-5.0\end{array}$ & $\begin{array}{l}13.5 \\
16.3\end{array}$ & $\begin{array}{r}9.9 \\
12.8\end{array}$ \\
\hline $\begin{array}{l}\text { Deposit money banks } \\
\text { (In millions of euros) }\end{array}$ & $\begin{array}{r}-25,049 \\
-3,347\end{array}$ & $\begin{array}{r}-39,584 \\
-5,308\end{array}$ & $\begin{array}{r}-36,161 \\
-4,959\end{array}$ & $\begin{array}{r}-28,533 \\
-3,915\end{array}$ & $\begin{array}{r}-30,788 \\
-4,214\end{array}$ & $\begin{array}{r}-34,891 \\
-4,806\end{array}$ & $\begin{array}{l}33.9 \\
31.0\end{array}$ & $\begin{array}{l}42.1 \\
38.3\end{array}$ & $\begin{array}{l}35.6 \\
34.8\end{array}$ & $\begin{array}{l}91.1 \\
86.4\end{array}$ & $\begin{array}{l}22.9 \\
25.9\end{array}$ & $\begin{array}{r}-11.9 \\
-9.5\end{array}$ \\
\hline Net Domestic Assets & 183,279 & 192,083 & 188,300 & 184,717 & 178,083 & 184,291 & 10.2 & 14.3 & 10.3 & 7.3 & -2.8 & -4.1 \\
\hline Domestic credit (CNB definition) $1 /$ & 261,792 & 264,945 & 255,841 & 228,494 & 227,518 & 229,602 & 15.8 & 14.7 & 9.0 & -4.6 & -13.1 & -13.3 \\
\hline Claims on government, net $2 /$ & 20,475 & 28,504 & 27,578 & 29,640 & 22,031 & 28,570 & 45.0 & 93.7 & 110.9 & 127.1 & 7.6 & 0.2 \\
\hline Claims on other domestic sectors $3 /$ & 230,905 & 232,862 & 228,924 & 226,933 & 229,588 & 231,790 & 10.6 & 9.3 & 4.9 & 2.0 & -0.6 & -0.5 \\
\hline Other items (net) & $-78,513$ & $-72,862$ & $-67,541$ & $-43,776$ & $-49,435$ & $-45,312$ & 31.5 & 15.7 & 5.6 & -35.0 & -37.0 & -37.8 \\
\hline Broad Money & 225,018 & 218,627 & 218,416 & 224,087 & 223,095 & 222,043 & 4.3 & 3.3 & 1.1 & -1.2 & -0.9 & 1.6 \\
\hline Narrow Money & 55,222 & 46,637 & 47,699 & 45,559 & 47,182 & 47,726 & -4.6 & -11.7 & -12.3 & -15.1 & -14.6 & 2.3 \\
\hline Currency outside banks & 17,051 & 15,826 & 16,915 & 16,013 & 15,282 & 14,775 & 6.5 & 3.2 & 0.0 & -3.3 & -10.4 & -6.6 \\
\hline Demand deposits & 38,171 & 30,810 & 30,784 & 29,547 & 31,900 & 32,951 & -8.8 & -17.8 & -17.9 & -20.4 & -16.4 & 6.9 \\
\hline Quasi Money & 169,796 & 171,990 & 170,717 & 178,527 & 175,913 & 174,317 & 7.5 & 8.3 & 5.6 & 3.1 & 3.6 & 1.4 \\
\hline Kuna-denominated & 52,601 & 49,125 & 46,828 & 45,101 & 40,502 & 36,992 & -4.1 & -9.1 & -11.6 & -18.4 & -23.0 & -24.7 \\
\hline Foreign currency-denominated & 117,195 & 122,865 & 123,889 & 133,426 & 135,411 & 137,325 & 13.7 & 17.3 & 14.0 & 13.1 & 15.5 & 11.8 \\
\hline \multicolumn{13}{|l|}{ Balance Sheet of the Croatian National Bank } \\
\hline Net Foreign Assets & 66,789 & 66,128 & 66,277 & 67,902 & 75,800 & 72,644 & -2.1 & -7.9 & -8.4 & -2.9 & 15.6 & 11.4 \\
\hline Of which: Banks' reserves in foreign currency & 8,008 & 4,582 & 4,669 & 4,778 & 5,042 & 4,711 & -9.4 & -18.5 & -17.9 & -13.5 & -5.1 & 0.2 \\
\hline Net International Reserves & 58,745 & 61,539 & 60,901 & 63,104 & 68,426 & 67,900 & 7.4 & 10.7 & 8.4 & 10.6 & 16.7 & 11.1 \\
\hline Net Domestic Assets & $-8,982$ & $-8,775$ & $-6,454$ & $-10,282$ & $-14,566$ & $-13,183$ & -10.6 & -6.6 & -3.7 & -5.9 & -9.7 & -7.7 \\
\hline Of which: Claims on government (net) & -205 & -383 & -961 & -278 & $-4,169$ & $-2,188$ & 0.0 & -0.1 & -0.5 & 0.3 & -6.9 & -3.1 \\
\hline Claims on banks & 14 & 1,397 & 2,426 & 14 & 14 & 13 & -6.3 & -0.2 & 1.1 & 0.0 & 0.0 & -2.4 \\
\hline Of which: open market operations & 0 & 1,359 & 2,412 & 0 & 0 & 0 & -4.3 & -0.2 & 1.1 & 0.0 & 0.0 & -2.4 \\
\hline Claims on other domestic sectors & 64 & 64 & 4 & 4 & 4 & 4 & 0.0 & 0.0 & -0.1 & -0.1 & -0.1 & -0.1 \\
\hline Other items (net) & $-8,855$ & $-9,853$ & $-7,923$ & $-10,022$ & $-10,414$ & $-11,012$ & -4.3 & -6.2 & -4.2 & -6.1 & -2.7 & -2.0 \\
\hline Base Money & 57,807 & 57,352 & 59,823 & 57,620 & 61,233 & 59,461 & -12.7 & -14.4 & -12.1 & -8.7 & 5.9 & 3.7 \\
\hline Currency & 17,051 & 15,826 & 16,915 & 16,013 & 15,282 & 14,775 & 6.5 & 3.2 & 0.0 & -3.3 & -10.4 & -6.6 \\
\hline Deposits & 40,756 & 41,526 & 42,908 & 41,607 & 45,951 & 44,686 & -18.8 & -19.7 & -16.1 & -10.7 & 12.7 & 7.6 \\
\hline Of which: Settlement accounts & 9,520 & 9,308 & 11,098 & 9,689 & 12,025 & 10,630 & 26.0 & 4.4 & 47.8 & 47.7 & 26.3 & 14.2 \\
\hline Statutory reserves in kuna 4 / & 19,223 & 24,080 & 23,493 & 23,662 & 23,601 & 22,055 & -20.8 & 6.4 & 2.2 & 2.5 & 22.8 & -8.4 \\
\hline Statutory reserves in foreign currency & 8,008 & 4,582 & 4,669 & 4,778 & 5,042 & 4,711 & -43.8 & -73.1 & -72.3 & -64.1 & -37.0 & 2.8 \\
\hline Reserve Money (CNB definition) 5/ & 49,743 & 52,718 & 55,101 & 52,791 & 56,142 & 54,694 & -4.2 & 5.5 & 7.7 & 6.1 & 12.9 & 3.7 \\
\hline \multicolumn{13}{|l|}{ Memorandum items: } \\
\hline Nominal GDP (yearly total) & 342,158 & 340,956 & 338,709 & 334,622 & 333,063 & 333,836 & $\ldots$ & $\ldots$ & $\ldots$ & $\ldots$ & $\ldots$ & $\ldots$ \\
\hline Narrow money multiplier & 0.96 & 0.81 & 0.80 & 0.79 & 0.77 & 0.80 & $\ldots$ & $\ldots$ & $\ldots$ & $\ldots$ & $\ldots$ & $\ldots$ \\
\hline Broad money multiplier & 3.89 & 3.81 & 3.65 & 3.89 & 3.64 & 3.73 & $\ldots$ & $\ldots$ & $\ldots$ & $\ldots$ & $\ldots$ & $\ldots$ \\
\hline Broad money (in percent of GDP) & 65.8 & 64.1 & 64.5 & 67.0 & 67.0 & 66.5 & $\ldots$ & $\ldots$ & $\ldots$ & $\ldots$ & $\ldots$ & $\ldots$ \\
\hline Foreign currency in percent of broad money & 52.1 & 56.2 & 56.7 & 59.5 & 60.7 & 61.8 & $\ldots$ & $\ldots$ & $\ldots$ & $\ldots$ & $\ldots$ & $\ldots$ \\
\hline Credit to other domestic sectors: stock (in percent of GDP) & 67.5 & 68.3 & 67.6 & 67.8 & 68.9 & 69.4 & $\ldots$ & $\ldots$ & $\ldots$ & $\ldots$ & $\ldots$ & $\ldots$ \\
\hline Credit to other domestic sectors: 12-month flow (in percent of GDP) & 6.5 & 5.8 & 3.2 & 1.3 & -0.4 & -0.3 & $\ldots$ & $\ldots$ & $\ldots$ & $\ldots$ & $\ldots$ & $\ldots$ \\
\hline
\end{tabular}

Sources: Croatian National Bank; and Fund staff estimates.

1/ Comprises net claims on central government, gross claims on local government, and claims on other domestic sectors.

2/ Comprises claims on central government and funds, and local government and funds, net of their deposits in the banking system. Central government funds include the Croatian Bank for Reconstruction and Development (HBOR).

3/ Comprises claims on households, enterprises, other banking institutions (housing savings banks, savings and loan cooperatives, and investment funds), and other financial institutions 4/ From 2007, includes obligatory CNB bills.

5 / Excludes statutory reserves in foreign currency. 
Table 7. Croatia: Financial Soundness Indicators, 2006-09

(Banks, in percent, unless otherwise indicated)

\begin{tabular}{|c|c|c|c|c|c|c|c|}
\hline & 2006 & 2007 & 2008 & Q1 2009 & Q2 2009 & Q3 2009 & Q4 2009 \\
\hline \multicolumn{8}{|l|}{ Core Set } \\
\hline Regulatory capital to risk-weighted assets & 14.4 & 16.9 & 15.4 & 15.6 & 16.1 & 16.2 & 16.0 \\
\hline Regulatory Tier I capital to risk-weighted assets & 13.3 & 16.6 & 15.2 & 15.3 & 15.6 & 15.6 & 15.3 \\
\hline Nonperforming loans net of loan-loss provisions to capital & 14.0 & 11.3 & 12.8 & 14.1 & 17.1 & 17.2 & 22.2 \\
\hline Nonperforming loans to total gross loans $1 /$ & 5.2 & 4.8 & 4.9 & 5.2 & 6.1 & 6.4 & 7.8 \\
\hline \multicolumn{8}{|l|}{ Sectoral distribution of loans to total loans } \\
\hline Nonfinancial corporations & 40.0 & 38.5 & 38.2 & 37.4 & 37.3 & 37.0 & 37.5 \\
\hline Households & 49.4 & 50.7 & 49.8 & 47.9 & 47.2 & 46.7 & 46.7 \\
\hline Other sectors & 10.7 & 10.8 & 12.1 & 14.7 & 15.4 & 16.3 & 15.8 \\
\hline Return on assets & 1.5 & 1.6 & 1.6 & 1.6 & 1.4 & 1.3 & 1.2 \\
\hline Return on equity & 12.7 & 10.9 & 9.9 & 9.4 & 8.4 & 7.4 & 6.7 \\
\hline Net interest income to gross income & 60.7 & 60.5 & 60.0 & 57.6 & 57.7 & 55.5 & 55.5 \\
\hline Noninterest expenses to gross income & 70.7 & 68.9 & 65.4 & 66.8 & 69.5 & 72.6 & 74.9 \\
\hline Liquid assets to total assets $2 /$ & 12.6 & 12.7 & 11.7 & 7.9 & 9.6 & 10.9 & 11.7 \\
\hline Liquid assets to short-term liabilities $2 /$ & 47.0 & 49.3 & 51.9 & 40.4 & 48.2 & 55.1 & 59.0 \\
\hline Net open position in foreign exchange to capital & 2.6 & 4.3 & 1.5 & 5.1 & 5.1 & 7.3 & 5.5 \\
\hline \multicolumn{8}{|l|}{ Encouraged Set } \\
\hline \multicolumn{8}{|l|}{ Deposit Takers $3 /$} \\
\hline Capital to assets & 10.3 & 12.5 & 13.5 & 13.9 & 14.0 & 14.0 & 13.9 \\
\hline Large exposures to capital & 77.0 & 58.4 & 45.7 & 33.6 & 33.7 & 40.0 & 53.4 \\
\hline \multicolumn{8}{|l|}{ Geographical distribution of loans to total loans } \\
\hline Residents & 99.5 & 99.3 & 99.2 & 99.3 & 99.3 & 99.3 & 99.4 \\
\hline Nonresidents & 0.5 & 0.7 & 0.8 & 0.7 & 0.7 & 0.7 & 0.6 \\
\hline Gross asset position in derivatives to capital & 0.9 & 0.6 & 0.2 & 1.1 & 1.0 & 0.7 & 0.4 \\
\hline Gross liability position in derivatives to capital & 0.7 & 0.9 & 3.2 & 1.1 & 0.6 & 0.6 & 0.8 \\
\hline Noninterest income to total income & 43.4 & 44.5 & 40.0 & 42.4 & 42.3 & 44.5 & 44.5 \\
\hline Personnel expenses to noninterest expenses & 33.8 & 34.4 & 35.9 & 34.5 & 33.0 & 31.0 & 29.3 \\
\hline Spread between domestic lending and deposit rates & 8.2 & 7.0 & 7.2 & 7.5 & 7.9 & 8.1 & 8.4 \\
\hline Spread between foreign exchange lending and deposit rates & 3.3 & 3.2 & 3.8 & 3.6 & 3.8 & 3.9 & 4.0 \\
\hline Noninterbank loans to noninterbank deposits & 107.6 & 105.6 & 114.2 & 121.6 & 120.9 & 116.0 & 116.2 \\
\hline Foreign currency-denominated loans to total loans 4 / & 69.6 & 59.8 & 65.4 & 68.3 & 69.4 & 71.0 & 72.7 \\
\hline Foreign currency-denominated liabilities to total liabilities 4 / & 78.0 & 73.6 & 75.8 & 76.1 & 76.5 & 77.5 & 78.7 \\
\hline Net open position in equities to capital & 0.1 & 0.2 & 0.0 & 0.0 & 0.0 & 0.0 & 0.0 \\
\hline \multicolumn{8}{|l|}{ Other Financial Corporations (OFCs) } \\
\hline OFCs' assets to total financial system assets & 23.6 & 26.0 & 22.3 & 22.6 & 23.1 & 23.3 & 23.4 \\
\hline OFCs' assets to GDP & 32.3 & 38.6 & 31.2 & 31.5 & 32.7 & 33.9 & 35.0 \\
\hline \multicolumn{8}{|l|}{ Nonfinancial Corporations 5/ } \\
\hline Total debt to equity & 43.4 & 50.6 & 58.0 & $\ldots$ & $\ldots$ & $\ldots$ & $\cdots$ \\
\hline Return on equity & 5.2 & 5.8 & 3.9 & $\cdots$ & $\cdots$ & $\cdots$ & $\cdots$ \\
\hline Net foreign exchange exposure to equity & 11.1 & 9.6 & 10.4 & $\ldots$ & $\ldots$ & $\ldots$ & $\ldots$ \\
\hline \multicolumn{8}{|l|}{ Households } \\
\hline Bank loans to households to GDP & 32.4 & 34.9 & 40.4 & 40.7 & 40.1 & 40.2 & 40.6 \\
\hline Household debt service (interest) payments to income & 5.2 & 5.5 & $\ldots$ & 0.0 & 0.0 & 0.0 & 0.0 \\
\hline \multicolumn{8}{|l|}{ Real Estate Markets } \\
\hline Residential real estate prices (annual percentage increase) & 17.5 & 9.0 & 5.6 & $\ldots$ & -5.3 & 0.0 & -3.0 \\
\hline Residential real estate loans to total loans & 19.5 & 20.7 & 21.1 & 20.6 & 20.4 & 20.6 & 20.8 \\
\hline Commercial real estate loans to total loans & $\ldots$ & $\ldots$ & $\ldots$ & $\ldots$ & $\ldots$ & $\ldots$ & $\ldots$ \\
\hline \multicolumn{8}{|l|}{ Other Indicators } \\
\hline Loan-loss provisions to nonperforming loans & 56.8 & 54.4 & 48.7 & 47.3 & 44.2 & 46.0 & 42.5 \\
\hline Change in credit to GDP ratio & 14.0 & 9.2 & 9.1 & 10.4 & 7.0 & 5.4 & 1.7 \\
\hline Net interest income to average total assets & 2.7 & 2.6 & 2.8 & 2.8 & 2.7 & 2.6 & 2.5 \\
\hline Noninterest expenses to average total assets & 3.2 & 3.0 & 3.0 & 3.2 & 3.3 & 3.4 & 3.4 \\
\hline Loans to assets & 61.6 & 62.7 & 66.6 & 69.6 & 68.4 & 67.5 & 66.6 \\
\hline Liquid assets to total deposits & 18.9 & 18.8 & 17.4 & 11.8 & 14.4 & 15.9 & 17.3 \\
\hline Net claims on government to total assets & 5.5 & 4.1 & 5.6 & 8.0 & 7.9 & 8.1 & 7.2 \\
\hline Foreign currency deposits to total deposits & 64.6 & 57.2 & 59.7 & 63.7 & 64.0 & 66.9 & 67.7 \\
\hline
\end{tabular}

Source: Croatian National Bank.

1/ Assets include gross loans, interbank loans, investment portfolio of banks, total interest income, total off-balance sheet claims.

2/ Liquid assets are on a net basis. They include deposits at banks and at the central bank, short-term government and central bank paper,

and overnight loans extended; less required reserve funds, central bank loans received, and overnight loans received. The sharp decline in

liquidity in 2005 coincided with the start of reverse repo operations by the CNB that gave banks market-based access to liquidity when needed.

3/ Commercial banks only. End-year FSIs, based on audited annual financial statements, can differ slightly from quarterly data.

4/ Includes kuna-denominated instruments linked to foreign currencies.

5/ Based on unconsolidated audited financial statements following IAS; not in line with the IMF FSI Compilation Guide. 
Table 8. Croatia: Indicators of External and Financial Vulnerability, 2004-09

(In percent, unless otherwise indicated)

\begin{tabular}{|c|c|c|c|c|c|c|c|}
\hline & \multirow[t]{2}{*}{2004} & \multirow[t]{2}{*}{2005} & \multirow[t]{2}{*}{2006} & \multirow[t]{2}{*}{2007} & \multirow[t]{2}{*}{2008} & \multicolumn{2}{|c|}{ Latest } \\
\hline & & & & & & Value & Date \\
\hline \multicolumn{8}{|l|}{ External indicators } \\
\hline Real effective exchange rate (using consumer prices) $1 /, 2000=100$ & 107.6 & 109.7 & 110.7 & 111.4 & 113.7 & 112.3 & Mar-10 \\
\hline Exports of goods and services (volumes, percentage change, yoy) 2 & 5.4 & 3.7 & 6.5 & 4.3 & 1.7 & -16.2 & Q4-09 \\
\hline Imports of goods and services (volumes, percentage change, yoy) 2 I & 4.7 & 3.9 & 7.4 & 6.5 & 3.6 & -20.7 & Q4 -09 \\
\hline Current account deficit (millions of euros) 3/ & $-1,434$ & $-1,976$ & $-2,715$ & $-3,237$ & $-4,371$ & $-2,361$ & Q4-09 \\
\hline Current account deficit in percent of GDP $3 /$ & -4.4 & -5.5 & -6.9 & -7.6 & -9.2 & -5.2 & Q4 -09 \\
\hline Capital and financial account in percent of GDP $3 /$ & 7.9 & 11.0 & 13.0 & 11.3 & 11.9 & 8.7 & Q4-09 \\
\hline Gross official reserves (millions of euros) & 6,436 & 7,438 & 8,725 & 9,307 & 8,926 & 10,376 & Mar-10 \\
\hline Gross official reserves in percent of broad money (M4) & 35.3 & 35.5 & 35.1 & 31.6 & 29.7 & 34.0 & Mar-10 \\
\hline Gross official reserves in percent of reserve money & 145.5 & 135.8 & 138.3 & 131.3 & 134.3 & 135.0 & Mar-10 \\
\hline Gross official reserves in months of current year's imports of goods and NFS & 4.8 & 5.1 & 5.3 & 5.2 & 4.5 & 6.7 & Mar-10 \\
\hline Gross usable international reserves in percent of domestic FX deposits & 47.2 & 47.7 & 53.8 & 52.3 & 50.2 & 52.3 & Mar-10 \\
\hline CNB net international reserves (NIR; millions of euros) & 5,026 & 5,604 & 6,464 & 7,349 & 7,849 & 9365 & Feb-10 \\
\hline CNB NIR in months of current year's imports of goods and NFS & 3.7 & 3.8 & 4.0 & 4.1 & 4.0 & 6.0 & Feb-10 \\
\hline Short-term debt (by residual maturity, in percent of NIR) & 118.1 & 155.9 & 153.8 & 115.8 & 163.7 & 156.3 & Q4-09 \\
\hline Short-term debt and current account deficit net of FDI (in percent of NIR) & 132.0 & 158.7 & 150.0 & 131.4 & 181.2 & 165.1 & Q4 -09 \\
\hline Total external debt, percent of GDP & 70.0 & 72.1 & 74.9 & 77.6 & 85.1 & 97.4 & Dec-09 \\
\hline External debt service to export ratio $3 /$ & 24.4 & 27.2 & 37.5 & 37.8 & 34.2 & 50.8 & Dec-09 \\
\hline \multicolumn{8}{|l|}{ Financial indicators } \\
\hline General government debt in percent of GDP & 37.9 & 38.4 & 35.8 & 33.2 & 29.3 & 35.4 & Dec-09 \\
\hline Domestic in percent of GDP & 17.4 & 21.2 & 21.3 & 20.6 & 20.4 & 24.1 & Dec-09 \\
\hline Foreign in percent of GDP & 20.5 & 17.2 & 14.5 & 12.6 & 8.9 & 11.3 & Dec-09 \\
\hline Broad money (M4, percentage change, yoy) & 8.6 & 10.5 & 18.0 & 18.3 & 4.3 & -0.9 & Mar-10 \\
\hline Claims on other domestic sectors (change, yoy) & 14.0 & 17.4 & 23.1 & 15.0 & 10.6 & -0.6 & Mar-10 \\
\hline Short-term interest rate (in percent, e.o.p.) & 4.8 & 3.5 & 2.8 & 6.8 & 6.8 & 1.4 & Dec-09 \\
\hline Stock market CROBEX index (1000 at July 1, 1997), e.o.p. & 1,565 & 1,998 & 3,211 & 5,239 & 5,239 & 2,052 & May-10 \\
\hline Zagreb Stock Exchange, capitalization (stocks, percent of GDP) & 35 & 44 & 70 & 125 & 52 & 55 & Apr-10 \\
\hline Bond yield spreads (EMBI Global, e.o.p.) & 42 & 36 & 40 & 94 & 553 & 279 & May-10 \\
\hline \multicolumn{8}{|l|}{ Debt ratings: Moody's: } \\
\hline Government bonds, domestic currency & Baa1 & Baa1 & Baa1 & Baa1 & Baa2 & Baa3 & May-10 \\
\hline Government bonds, foreign currency & Baa3 & Ваa3 & Baa3 & Вaа3 & Baa3 & Baa3 & May-10 \\
\hline \multicolumn{8}{|l|}{ Foreign debt ratings } \\
\hline Fitch: domestic currency LT & $\mathrm{BBB}+$ & $\mathrm{BBB}+$ & $\mathrm{BBB}+$ & $\mathrm{BBB}+$ & $\mathrm{BBB}+$ & BBB & May-10 \\
\hline Fitch: foreign currency LT & BBB- & BBB- & BBB- & BBB- & BBB- & BBB- & May-10 \\
\hline Standard and Poor's: domestic currency LT & $\mathrm{BBB}+$ & $\mathrm{BBB}+$ & $\mathrm{BBB}+$ & $\mathrm{BBB}+$ & BBB & BBB & May-10 \\
\hline Standard and Poor's: foreign currency LT & BBB & BBB & BBB & BBB & BBB & BBB & May-10 \\
\hline \multicolumn{8}{|l|}{ Banking system: } \\
\hline Regulatory capital to risk-weighted assets & 16.0 & 15.2 & 14.4 & 16.9 & 15.4 & 16.0 & Q4-09 \\
\hline Nonperforming loans to total loans & 7.5 & 6.2 & 5.2 & 4.8 & 4.9 & 7.8 & Q4-09 \\
\hline Loan-loss provisions to non-performing loans & 62.3 & 60.0 & 56.8 & 54.4 & 48.7 & 42.5 & Q4 -09 \\
\hline Net open foreign exchange position to capital & 18.2 & 7.4 & 2.6 & 4.3 & 1.5 & 5.5 & Q4 -09 \\
\hline Foreign currency deposits to total deposits $4 /$ & 74.2 & 73.1 & 64.6 & 57.2 & 59.7 & 67.7 & Q4 -09 \\
\hline Foreign currency loans to total loans 4 I & 76.7 & 78.5 & 69.6 & 59.8 & 65.4 & 72.7 & Q4-09 \\
\hline
\end{tabular}

Sources: Croatian National Bank; Ministry of Finance; Central Bureau of Statistics; Bloomberg; MediaScan; and Fund staff estimates.

1/ An increase in the index reflects an appreciation; annual averages through 2008.

2/ National accounts concept.

$3 /$ Sum of four quarters to the latest observation.

4/ Including foreign currency-linked deposits and loans. 
Table 9. Croatia: Public Sector Debt Sustainability Framework, 2005-15

(In percent of GDP, unless otherwise indicated)

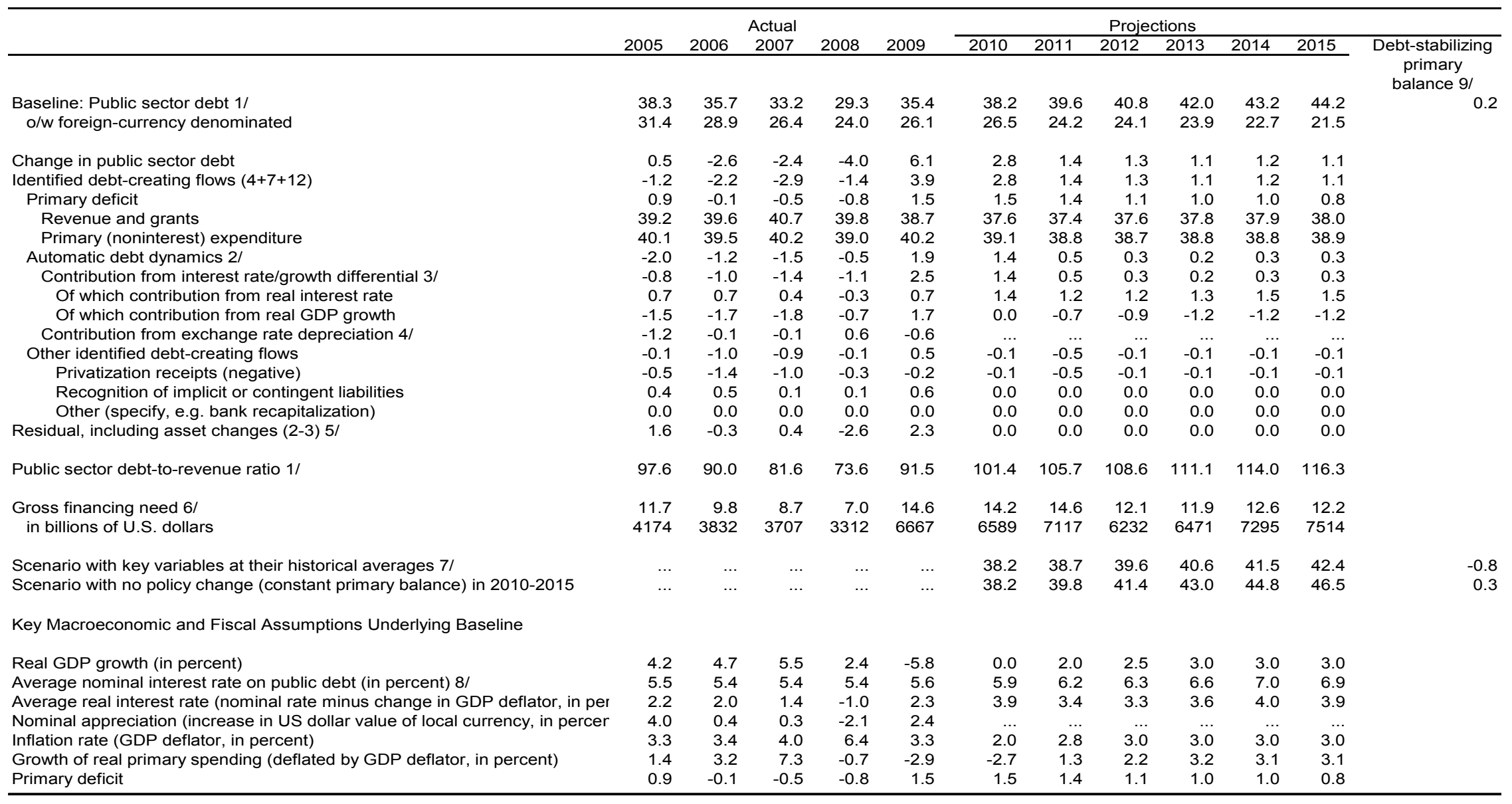

$1 /$ Indicate coverage of public sector, e.g., general government or nonfinancial public sector. Also whether net or gross debt is used.

2/ Derived as $[(r-\pi(1+g)-g+\alpha \varepsilon(1+r)] /(1+g+\pi+g \pi))$ times previous period debt ratio, with $r=$ interest rate; $\pi=$ growth rate of GDP deflator; $g=$ real GDP growth rate; $\alpha=$ share of foreign-currency denominated debt; and $\varepsilon=$ nominal exchange rate depreciation (measured by increase in local currency value of U.S. dollar).

$3 /$ The real interest rate contribution is derived from the denominator in footnote $2 /$ as $r-\pi(1+g)$ and the real growth contribution as $-g$.

$4 /$ The exchange rate contribution is derived from the numerator in footnote $2 /$ as $\alpha \varepsilon(1+r)$.

$5 /$ For projections, this line includes exchange rate changes.

6/ Defined as public sector deficit, plus amortization of medium and long-term public sector debt, plus short-term debt at end of previous period.

7/ The key variables include real GDP growth; real interest rate; and primary balance in percent of GDP.

8/ Derived as nominal interest expenditure divided by previous period debt stock.

9/ Assumes that key variables (real GDP growth, real interest rate, and other identified debt-creating flows) remain at the level of the last projection year. 
Table 10. Croatia: External Debt Sustainability Framework, 2005-15

(In percent of GDP, unless otherwise indicated)

\begin{tabular}{|c|c|c|c|c|c|c|c|c|c|c|c|c|}
\hline & \multicolumn{5}{|c|}{ Actual } & \multicolumn{7}{|c|}{ Projections } \\
\hline & 2005 & 2006 & 2007 & 2008 & 2009 & 2010 & 2011 & 2012 & 2013 & 2014 & 2015 & Debt-stabilizing \\
\hline Baseline: External debt & 72.1 & 74.9 & 77.6 & 85.1 & 97.4 & 99.9 & 98.6 & 98.5 & 98.7 & 98.9 & 99.3 & $\begin{array}{c}\text { current account } 6 / \\
-5.4\end{array}$ \\
\hline Change in external debt & 2.1 & 2.8 & 2.8 & 7.5 & 12.3 & 2.5 & -1.3 & -0.1 & 0.2 & 0.2 & 0.4 & \\
\hline Identified external debt-creating flows $(4+8+9)$ & -3.9 & -5.8 & -7.1 & -5.0 & 5.9 & 1.8 & 0.8 & 0.1 & 0.1 & 0.0 & 0.4 & \\
\hline Current account deficit, excluding interest payments & 3.1 & 4.3 & 4.3 & 6.0 & 1.9 & 1.7 & 1.6 & 1.6 & 2.1 & 2.6 & 3.0 & \\
\hline Deficit in balance of goods and services & 6.2 & 6.8 & 7.4 & 8.1 & 3.8 & 3.7 & 3.6 & 3.5 & 3.7 & 4.2 & 4.5 & \\
\hline Exports & 42.8 & 43.5 & 42.7 & 42.0 & 35.2 & 36.4 & 36.8 & 37.1 & 37.3 & 37.2 & 37.6 & \\
\hline Imports & 48.9 & 50.2 & 50.1 & 50.1 & 39.0 & 40.0 & 40.4 & 40.6 & 41.0 & 41.4 & 42.0 & \\
\hline Net non-debt creating capital inflows (negative) & -3.6 & -6.5 & -8.1 & -6.8 & -2.2 & -3.6 & -3.2 & -3.4 & -3.5 & -3.7 & -3.8 & \\
\hline Automatic debt dynamics 1/ & -3.4 & -3.6 & -3.3 & -4.2 & 6.2 & 3.7 & 2.4 & 1.9 & 1.6 & 1.2 & 1.2 & \\
\hline Contribution from nominal interest rate & 2.4 & 2.6 & 3.2 & 3.3 & 3.2 & 3.7 & 4.3 & 4.3 & 4.4 & 4.0 & 4.0 & \\
\hline Contribution from real GDP growth & -2.7 & -3.1 & -3.7 & -1.7 & 5.1 & 0.0 & -1.9 & -2.3 & -2.8 & -2.8 & -2.8 & \\
\hline Contribution from price and exchange rate changes $2 /$ & -3.1 & -3.1 & -2.8 & -5.8 & -2.2 & 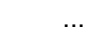 & $\ldots$ & $\ldots$ & $\ldots$ & $\ldots$ & $\ldots$ & \\
\hline Residual, incl. change in gross foreign assets (2-3) $3 /$ & 5.9 & 8.6 & 9.9 & 12.5 & 6.3 & 0.7 & -2.1 & -0.2 & 0.1 & 0.2 & -0.1 & \\
\hline External debt-to-exports ratio (in percent) & 168.6 & 172.3 & 181.8 & 202.5 & 276.5 & 274.7 & 268.0 & 265.6 & 264.6 & 265.6 & 264.1 & \\
\hline Gross external financing need (in billions of Euros) 4/ & 7.9 & 11.5 & 13.2 & 12.9 & 15.2 & 17.1 & 17.2 & 15.6 & 17.6 & 18.0 & 20.0 & \\
\hline in percent of GDP & 22.1 & 29.3 & 30.8 & 27.2 & 33.2 & 36.9 & 35.3 & 30.4 & 32.2 & 31.1 & 32.5 & \\
\hline Scenario with key variables at their historical averages $5 /$ & $\ldots$ & $\cdots$ & $\ldots$ & $\ldots$ & $\cdots$ & 99.9 & 95.7 & 93.7 & 92.0 & 90.3 & 88.4 & -7.3 \\
\hline \multicolumn{13}{|l|}{ Key Macroeconomic Assumptions Underlying Baseline } \\
\hline Real GDP growth (in percent) & 4.2 & 4.7 & 5.5 & 2.4 & -5.8 & 0.0 & 2.0 & 2.5 & 3.0 & 3.0 & 3.0 & \\
\hline GDP deflator in Euro (change in percent) & 4.7 & 4.5 & 3.9 & 8.0 & 2.6 & 1.6 & 2.7 & 3.0 & 3.0 & 3.0 & 3.0 & \\
\hline Nominal external interest rate (in percent) & 3.7 & 4.0 & 4.7 & 4.7 & 3.7 & 3.8 & 4.5 & 4.6 & 4.8 & 4.3 & 4.3 & \\
\hline Growth of exports (Euro terms, in percent) & 7.2 & 11.3 & 7.6 & 8.8 & -19.0 & 4.8 & 6.0 & 6.5 & 6.7 & 5.9 & 7.1 & \\
\hline Growth of imports (Euro terms, in percent) & 7.9 & 12.4 & 9.4 & 10.6 & -24.8 & 4.2 & 5.8 & 6.0 & 7.2 & 7.2 & 7.8 & \\
\hline Current account balance, excluding interest payments & -3.1 & -4.3 & -4.3 & -6.0 & -1.9 & -1.7 & -1.6 & -1.6 & -2.1 & -2.6 & -3.0 & \\
\hline Net non-debt creating capital inflows & 3.6 & 6.5 & 8.1 & 6.8 & 2.2 & 3.6 & 3.2 & 3.4 & 3.5 & 3.7 & 3.8 & \\
\hline
\end{tabular}

1/ Derived as $[r-g-\rho(1+g)+\varepsilon \alpha(1+r)] /(1+g+\rho+g \rho)$ times previous period debt stock, with $r=$ nominal effective interest rate on external debt; $\rho=$ change in domestic GDP deflator in US dollar terms, $g=$ real GDP growth rate, $\varepsilon=$ nominal appreciation (increase in dollar value of domestic currency), and $\alpha=$ share of domestic-currency denominated debt in total external debt.

$2 /$ The contribution from price and exchange rate changes is defined as $[-\rho(1+g)+\varepsilon \alpha(1+r)] /(1+g+\rho+g \rho)$ times previous period debt stock. $\rho$ increases with an appreciating domestic currency $(\varepsilon>0)$ and rising inflation (based on GDP deflator).

3/ For projection, line includes the impact of price and exchange rate changes.

4/ Defined as current account deficit, plus amortization on medium- and long-term debt, plus short-term debt at end of previous period. Excludes LT trade credit and movements in LT currency and deposits. 5/ The key variables include real GDP growth; nominal interest rate; dollar deflator growth; and both non-interest current account and non-debt inflows in percent of GDP.

6/ Long-run, constant balance that stabilizes the debt ratio assuming that key variables (real GDP growth, nominal interest rate, dollar deflator growth, and non-debt inflows in percent of GDP) remain at their levels

of the last projection year. 


\section{Annex I. Assessing Croatia’s Real Exchange Rate}

Staff's quantitative estimates of misalignment suggest that Croatia's real effective exchange rate could be slightly overvalued. Point estimates, which are subject to significant uncertainties, indicate overvaluation margin in the range of 4-10 percent (imposing multilateral consistency).

- The macroeconomic balance approach (Table 1). The underlying current account balance-proxied by the medium-term projected current account deficit under an assumption of unchanged polices - is estimated to be about 7 percent of GDP. The current account deficit norm is estimated to be about $4 \frac{1}{2}$ percent of GDP. Downward adjustment of the real effective exchange rate of 5-6 percent

\begin{tabular}{lr} 
Table 1. Macroeconomic Balance Approach & \\
\hline Projected medium-term CA balance, percent of GDP & -7.0 \\
CA norm, percent of GDP 1/ & -4.4 \\
Elasticity 2/ & 0.26 \\
RER gap, percent & 5.9 \\
Multilaterally consistent RER gap, percent & 4.9 \\
\hline 1/ Estimated based on CGER methodology. \\
2/ Current account elasticity is computed based on standard \\
elasticities for exports (-0.71) and imports (0.92) and exports \\
and imports of goods and services (in percent of GDP) in 2000-09.
\end{tabular}
would be required to close the gap between the sustainable level of the current account balance and the underling current account balance.

- $\quad$ The external sustainability approach (Table 2). The analysis suggests that stabilizing Croatia's net foreign asset position (NFA) at its 2007-08 average level would require keeping the current account deficit in the range of 4-6 percent of GDP, depending on the GDP growth assumption. The gap between the underlying current account and the NFA-stabilizing balance would suggest that Table 2. External Stability Approach Croatia's real effective

\begin{tabular}{|c|c|c|c|}
\hline & \multicolumn{3}{|c|}{ Real growth rate } \\
\hline & \multicolumn{2}{|c|}{2 Baseline: 3} & 4 \\
\hline NFA-stabilizing CA balance, percent of GDP 1/ & -4.1 & -4.9 & -5.6 \\
\hline RER gap, percent & 10.7 & 7.7 & 4.8 \\
\hline Multilaterally consistent RER gap, percent & 9.7 & 6.7 & 3.8 \\
\hline \multicolumn{4}{|l|}{ Memorandum items } \\
\hline Projected medium-term CA balance, percent of GDP & -7.0 & -7.0 & -7.0 \\
\hline Baseline NFA (2007-08 average), percent of GDP & -86.3 & -86.3 & -86.3 \\
\hline Elasticity $2 /$ & 0.26 & 0.26 & 0.26 \\
\hline
\end{tabular}

1/ Estimated based on CGER methodology.

$2 /$ Current account elasticity is computed based on standard elasticities for exports (-0.71) and imports (0.92) and exports and imports of goods and services (in percent of GDP) in 2000-09. exchange rate is overvalued by about 5-11 percent.

- The equilibrium real exchange rate approach (Table 3). The analysis suggests that Croatia's real effective exchange rate is broadly in line with its fundamentals: as of December 2009, the real effective exchange rate overvaluation is Table 3. Croatia: Equilibrium Real Exchange Rate Approach estimated to be below 4 percent.

\begin{tabular}{lcc}
\hline & Full sample 1/ & EU sample \\
\hline & \multicolumn{3}{c}{ (in percent) } \\
REER overvaluation (average 2009) & 3.6 & -0.2 \\
REER overvaluation (December 2009) & 3.7 & 0.0 \\
\hline
\end{tabular}

Note: Based on the model reported in Atoyan, 2008 (SM/08/168). $1 /$ Includes OECD-Eurostat and CIS countries. 


\section{AnNeX II: Government's ECONOMIC RECOVERY Program (ERP)}

The ERP aims to generate economic recovery and create a competitive economy using the following five levers. ${ }^{1}$

- Reduce public sector expenditures, while increasing its effectiveness and transparency;

- Redirect budget resources to targeted social transfers and economically viable capital investments;

- Reduce government intervention in economic activities through further privatization, and professional management of public enterprises and government institutions;

- Start a new investment cycle with economically measurable long-term effects, and maximum participation of the private sector; and

- Speed up implementation of reforms in judiciary, health care, pension insurance, and state and local government.

This comprehensive ten-year plan includes 131 measures in ten reform areas to be implemented during 2010-20. The authorities have developed a timeline and identified agencies for the implementation of these reforms. However, many of the measures are yet to be fine-tuned, and fiscal and growth impact of these measures has not been quantified. The following are some key measures expected to be implemented or commenced during 2010/11.

- Reduce the level and number of income tax rates.

- Abolish all tax exemptions in the income tax system.

- Reduce or abolish non-tax levies imposed by local government units and public agencies.

- Establish a central regulatory body for water, utility and similar fees within the competence of local self government.

- Prepare a plan for the reduction of government expenditure.

\footnotetext{
${ }^{1}$ The ERP was announced in late April and adopted in early May.
} 
- Reduce illiquidity through one-off payment of all debts under the Government's purview that are falling due by June 1, 2010.

- Maintain the payment schedule of 60 days and introduce the payment schedule of 45 days from January 1, 2011.

- Gradually harmonize the legal ages for early and mandatory retirement for men and women.

- Increase penalty for early retirement and introduce incentives for late retirement.

- Continue health care reform by rationalizing operations and health care institution network.

- Launch privatization of companies where the government owns minority shares. 


\section{ANNEX III. CREDIT SCHEMES}

Model A. This model aims to stimulate the provision of short term loans (up to 3 years) to finance working capital of companies. To provide banks with liquidity for such loans, the model involved a reduction in the reserve requirement from 14 to 13 percent, which released about HRK 2.9 billion ( 1 percent of GDP). The banks then provided a syndicated loan of HRK 2 billion at 3 percent interest rate to the Croatian Bank for Reconstruction and Development (HBOR). HBOR has subsequently started lending these funds to enterprises (selected by the banks) at an interest rate fixed below the market rates through commercial banks, which co-finance 60 percent of the loans using their own resources. The final interest rate charged to enterprises is determined in the loan auctions to bank organized by the HBOR. The model involves a risk sharing arrangement between banks and the HBOR. There has been a substantial interest in this model, and the first few auctions were significantly oversubscribed. However, the effective disbursement of these loans to the ultimate borrowers has been slow.

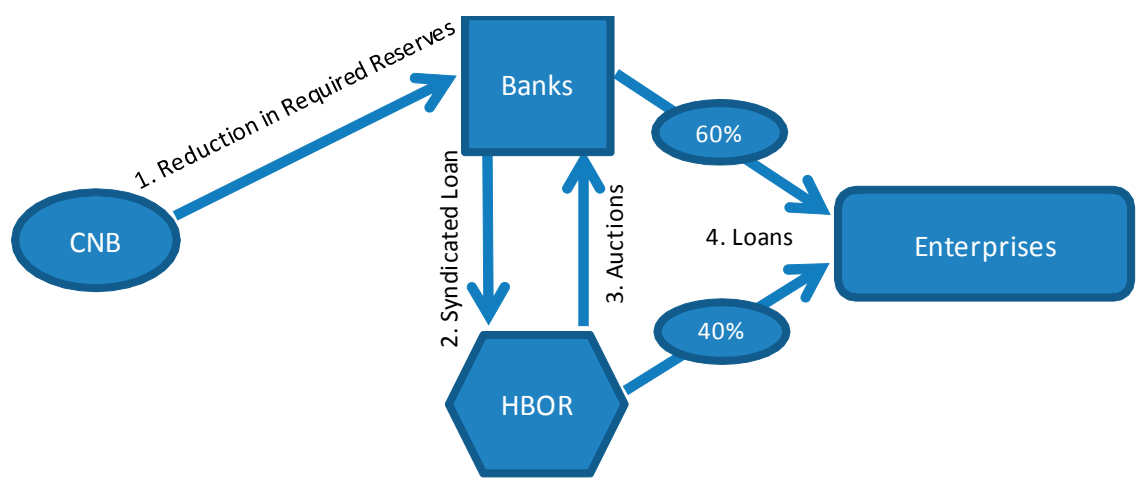

Model B. Under this model, the authorities established a fund for guaranteeing 25-50 percent of the risk on bank loans for developmental and investment projects with a maturity of up to 10 years. This model has had limited success so far, as the demand for long term loans is very weak.

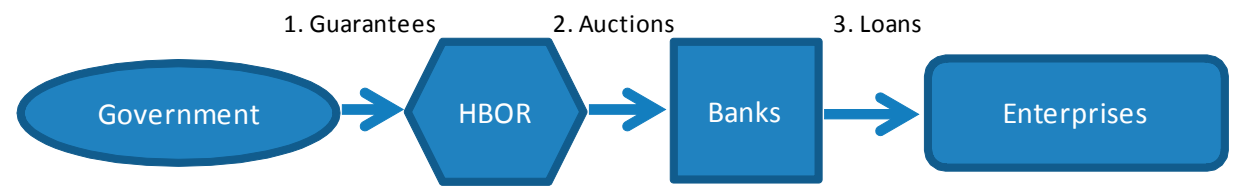


Model C. This model envisages debt-to-equity swaps. Government would write off the debt of troubled enterprises in exchange for an ownership stake transferred to the specially created economic cooperation funds. The enterprises would need to present a restructuring plan, and the intention is to provide this type of assistance for a period of 5 years or less. As of early May, this model has not been activated.

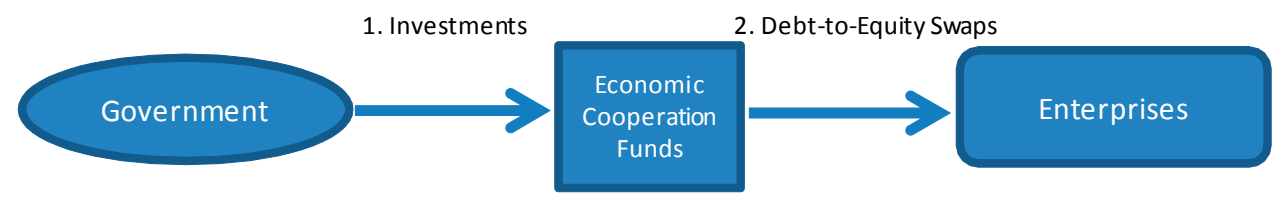




\section{INTERNATIONAL MONETARY FUND \\ REPUBLIC OF CROATIA \\ Staff Report for the 2010 Article IV Consultation-Informational Annex}

Prepared by the European Department

(In consultation with other departments)

June 3, 2010

Contents

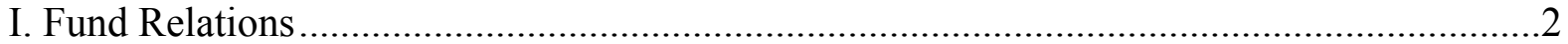

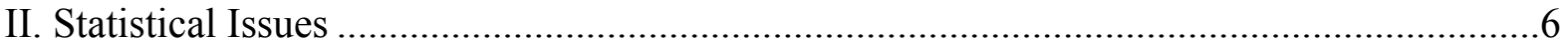

III. World Bank Relations......................................................................................... 10 


\section{Annex I. Croatia: Fund Relations}

(as of April 30, 2010)

I. Membership Status: Joined December 14, 1992; Article VIII.

II. General Resources Account:

Quota

Fund holdings of currency

Reserve position in Fund

III. SDR Department:

Net cumulative allocation

SDR million
$\begin{array}{r}347.34 \\ 303.25\end{array}$

Holdings $\underline{\text { SDR million }}$

365.10

364.94

0.16
\% Quota

100.00

99.96

0.04

IV. Outstanding Purchases and Loans: None

V. Financial Arrangements:

\begin{tabular}{|c|c|c|c|c|}
\hline Type & $\begin{array}{c}\text { Approval } \\
\text { Date }\end{array}$ & $\begin{array}{c}\text { Expiration } \\
\text { Date } \\
\end{array}$ & $\begin{array}{c}\text { Amount } \\
\text { Approved } \\
\text { (SDR million) }\end{array}$ & $\begin{array}{c}\text { Amount } \\
\text { Drawn } \\
\text { (SDR million) }\end{array}$ \\
\hline Stand-By & $8 / 04 / 2004$ & $11 / 15 / 2006$ & 99.00 & 0.00 \\
\hline Stand-By & $2 / 03 / 2003$ & $4 / 02 / 2004$ & 105.88 & 0.00 \\
\hline Stand-By & $3 / 19 / 2001$ & $5 / 18 / 2002$ & 200.00 & 0.00 \\
\hline $\mathrm{EFF}$ & $3 / 12 / 1997$ & $3 / 11 / 2000$ & 353.16 & 28.78 \\
\hline
\end{tabular}


VI. Projected Obligations to Fund (SDR million; based on present holdings of SDRs): ${ }^{1}$

Principal

Charges/Interest

Total
Forthcoming

\begin{tabular}{lllll}
\hline$\underline{2010}$ & $\underline{2011}$ & $\underline{2012}$ & $\underline{2013}$ & $\underline{2014}$ \\
$\underline{0.09}$ & $\underline{0.12}$ & $\underline{0.12}$ & $\underline{0.12}$ & $\underline{0.12}$ \\
$\underline{0.09}$ & $\underline{0.12}$ & $\underline{0.12}$ & $\underline{0.12}$ & $\underline{0.12}$
\end{tabular}

VII. Exchange Rate Arrangement:

In December 1991, Croatia left the Yugoslav dinar area and adopted the Croatian dinar as its sole legal tender. The Croatian dinar was replaced by the Croatian kuna on May 30, 1994. The exchange rate of the kuna is determined by supply and demand in the interbank market, with tight management by the CNB. Croatia's de facto exchange rate arrangement is classified as "stabilized arrangement" from July 1, 2009. The CNB transacts only in euros, U.S. dollars, and SDRs. On May 4, 2010 the official exchange rate was kuna 7.258114 per euro (middle rate).

VIII. Exchange Restrictions:

Croatia has accepted the obligations of Article VIII, Section 2-4 and maintains an exchange system that is free of restrictions on payments and transfers for current international transactions, except for restrictions that Croatia maintains solely for the preservation of national or international security that have been notified to the Fund pursuant to Executive Board Decision 144(52/51).

IX. Article IV Consultation:

The previous Article IV consultation with Croatia was concluded on June 2, 2009 (IMF Country Report No. 09/185 available at:

http://www.imf.org/external/country/hrv/index.htm). Croatia is on the 12-month consultation cycle.

\footnotetext{
${ }^{1}$ On December 27, 2002 Croatia made an early repurchase in respect of the entire amount of Fund credit outstanding. The charges shown below are net charges and assessments by the SDR Department.
} 
X. FSAP:

An FSAP Update mission took place in October-November 2007. The FSSA Update was published (IMF Country Report No. 160 available http://www.imf.org/external/country/hrv/index.htm).

The original FSAP was concluded with the completion of the 2002 Article IV consultation on August 5, 2002 on the basis of missions that took place in April 2001 and September 2001. The FSSA was published (IMF Country Report No. 02/180).

\section{Technical Assistance 2000-10: ${ }^{2}$}

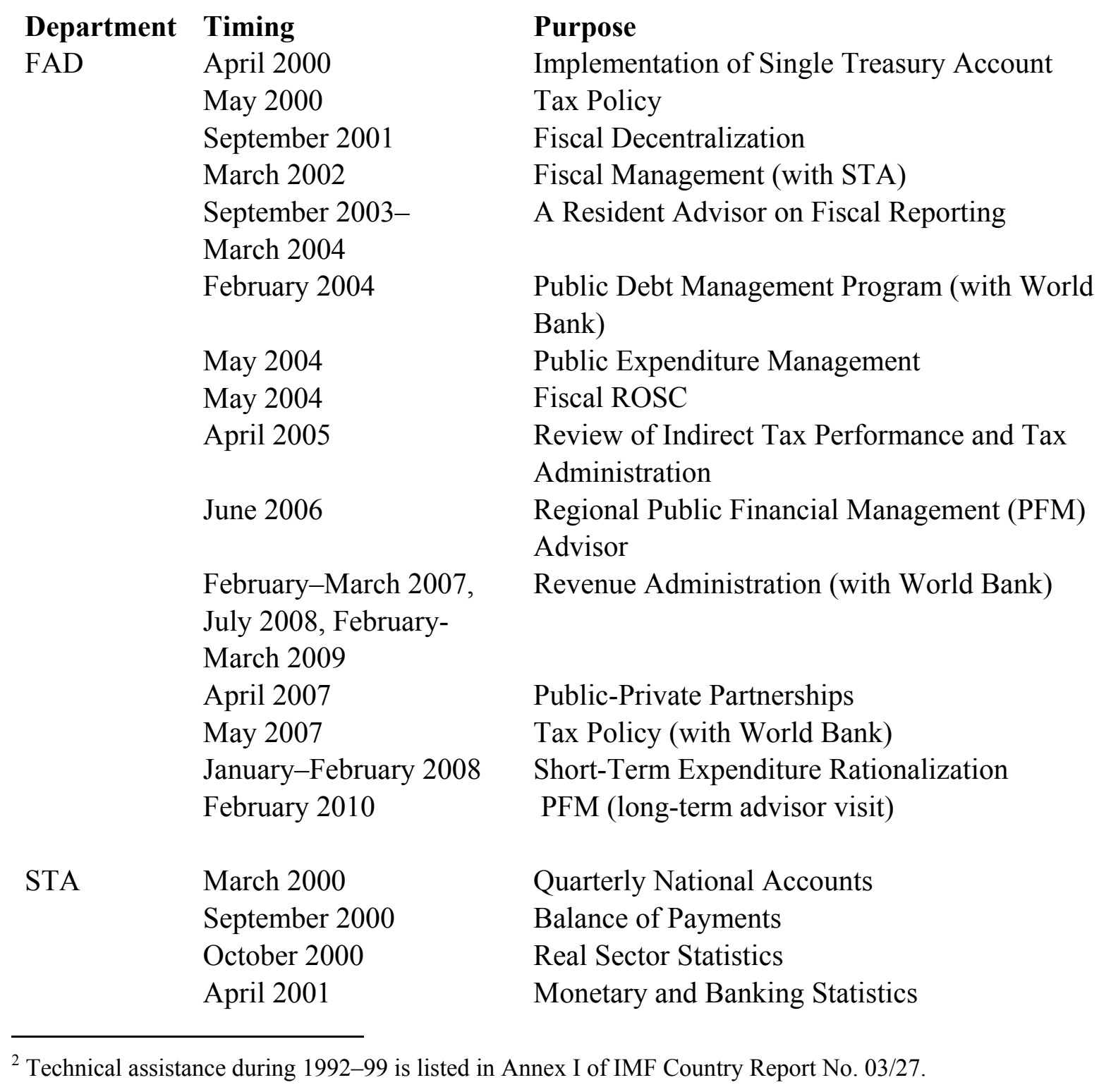

\section{Purpose}

Implementation of Single Treasury Account Tax Policy

Fiscal Decentralization

Fiscal Management (with STA)

A Resident Advisor on Fiscal Reporting

Public Debt Management Program (with World Bank)

Public Expenditure Management

Fiscal ROSC

Review of Indirect Tax Performance and Tax

Administration

Regional Public Financial Management (PFM)

Advisor

Revenue Administration (with World Bank)

Public-Private Partnerships

Tax Policy (with World Bank)

Short-Term Expenditure Rationalization

PFM (long-term advisor visit)

Quarterly National Accounts

Balance of Payments

Real Sector Statistics

Monetary and Banking Statistics

\footnotetext{
2 Technical assistance during 1992-99 is listed in Annex I of IMF Country Report No. 03/27.
} 
March 2002

October 2002, June 2004

September 2006

MCM

May-June 2000

March-April 2001

December 2001

April 2003

February 2004

January 2007-continuing
Accounting and Budgetary Classification (FAD)

Government Finance Statistics

Monetary and Financial Statistics

Coordination between CNB and the Ministry of Finance, Central Bank Law, Banking Law, and Money and Securities Markets

Central Bank Accounting Monetary Policy Instruments

Stress Testing and Foreign Exchange Reserve Management

Monetary Policy Instruments

Macro-Financial Modeling and Forecasting

XII. Resident Representative: The post closed in June 2007. 


\section{Annex II. Croatia: Statistical Issues}

1. Data provision is broadly adequate for effective surveillance, though some improvements would be desirable. While remedial action has been taken to improve data coverage and reliability in most cases, progress in some instances has been impeded by insufficient resources and issues regarding coordination among government agencies. Croatia subscribes to the Special Data Dissemination Standard.

\section{A. National Accounts}

2. The national accounts have undergone substantial improvements in the last few years. The Central Bureau of Statistics (CBS) publishes constant and current price data compiled in accordance with the 1995 ESA. Quarterly GDP estimates are disseminated at current prices and at constant (2000) prices for the main categories of expenditure and main industry groupings. Nonetheless, shortcomings remain. Significant discrepancies exist between expenditure-based and value-added-based GDP data, stemming from: (i) problems of coordination between the CBS and the Croatian National Bank $(\mathrm{CNB})$ in reconciling tourism receipts estimates; (ii) incomplete coverage of unincorporated businesses and the selfemployed (farmers, traders, and craftsmen); (iii) inadequate data for measuring changes in inventories; (iv) incomplete coverage of the informal sector; and (v) a lack of quarterly data for the seasonally volatile agricultural sector.

\section{B. Prices}

3. The CBS produces a monthly consumer price index, with expenditure weights (updated every five years) derived from a 2005 Household Budget Survey. Between rebasing, the weights are price-updated annually to December of the previous year. Data are collected at different time periods in the month for different product groups but in all cases between the thirteenth and the twenty-first day of each month. The indices are released around the fifteenth day of the following month. The price collection is confined to nine towns, but the weights are based on a sample of households in the whole country. A harmonized index of consumer prices (HICP) is also calculated in line with Eurostat methodology, but is not released for the time being to avoid confusion. A core CPI is also calculated based on a methodology developed by the CNB. The CBS also releases a monthly producer price index (PPI), usually on the eighth day of the following month. The weighting system of the PPI is based on the 2000 Annual Report of Industry and is changed every five years, while weights are partially corrected every year.

\section{Wages and Employment}

4. The CBS produces data on average net and gross earnings per person and employment by sector. Earning data include bonuses, sick pay, and meal allowances, and are based on monthly surveys covering 70 percent of workers in permanent employment in each industrial category. They do not cover a significant part of the working population, including persons employed in trade and crafts, contract workers, farmers, and the military and police. 
5. The number of registered unemployed overstates the actual level of unemployment. A preliminary Labor Force Survey, which meets ILO standards, was conducted for the first time in 1996 on 7,200 households. The sample was subsequently expanded and the survey is now being conducted on a regular basis. The CBS released semi-annual results from 1998, and began releasing quarterly results in 2007 with a lag of about four months.

\section{Government Finance Statistics}

6. The authorities have started presenting budget plans based on the ESA 95 framework, but government finance statistics produced on a monthly basis on the GFSM framework (GFS) have been available in the Monthly Statistical Review of the Ministry of Finance (MoF). Data normally come with a lag of about one quarter. Revenue data are reliable, and expenditure data on a cash basis are available according to GFS classifications (economic and functional) for the central budget and the budgetary funds. The data on central government financing in the MoF reports are not reconciled with those in the CNB's monetary survey and balance of payments data, with substantial discrepancies owing partly to different methodologies and definitions of government. Following the recommendations of the October 2002 GFS mission, a task force, comprising staff from the MoF, CNB, and CBS was formed to reconcile central government financing data produced by these institutions.

7. The detailed data on domestic public bonds published in the Monthly Statistical Review are now augmented by a central government debt table in the CNB Monthly Bulletin, which also reports stocks of central government guaranteed debt. The MoF prepared a database with government guarantees in July 2003 that has been used to monitor developments in the stock and flows of guarantees.

8. Data on the operations of local governments and consolidated general government are available on a quarterly basis. Local government data are partial as they include the operations of the 53 largest municipalities.

\section{E. Monetary Data}

9. Compilation of monetary statistics published by the CNB is consistent with the recommendations of the IMF's 2000 Monetary and Financial Statistics Manual (MFSM). Data on the monetary survey, including separate records for deposit money banks and the balance sheet of the CNB, are published monthly with four- and two-week lags, respectively. The CNB is planning to extend its statistical framework to balance sheet information of investment funds and insurance companies. In March 2002, the CNB started collecting financial information (balance sheets and investment structure) from investment and pension funds; the data are not yet published, but used for internal purposes. According to the CNB, the inclusion of other financial corporations in monetary statistics depends on the harmonization process of the monetary statistics with the statistical reporting requirements of the European Central Bank. In November 2006, the CNB reported monetary data in the format of Standardized Report Forms for December 2001 to the present. These data accord 
with the concepts and definitions in MFSM and were published, along with the corresponding metadata, in IFS and the IFS Supplement on Monetary and Financial Statistics.

\section{F. External Sector Statistics}

10. Quarterly balance of payments data are compiled broadly in accordance with the fifth edition of the IMF's Balance of Payments Manual. Data are generally available with a lag of three months and are subject to substantial revisions in subsequent releases; trade data are available with a lag of one month and data on international reserves are available the next day on request. Travel survey methodologies were modified in 2002, 2004, and again in 2005, while the method for estimating the cost of insurance and freight was modified in early 2004. Net errors and omissions have ranged from $2 \frac{1}{2}$ to $3 \frac{3}{4}$ percent of GDP since 2003, and are negative. The coverage and quality of portfolio investment data are reasonably complete and accurate.

11. A large part of external debt was contracted prior to the dissolution of the former Socialist Federal Republic of Yugoslavia and Croatia's share was agreed with Paris and London Club creditors in 1995 and 1998, respectively. The CNB compiles external debt data according to the requirements of External Debt Statistics: Guide for Compilers and Users, 2003, and began disseminating external debt data in the second quarter of 2003. The inclusion of hybrid and subordinated debt instruments, repos, late interest, and interest accruals and arrears has caused an upward adjustment in the external debt series compared to previously released data. Quarterly data on the international investment position are available on the CNB website up to 2009:Q4. 


\title{
Croatia: Table of Common Indicators Required for Surveillance
}

\author{
(as of May 20, 2010)
}

\begin{tabular}{|c|c|c|c|c|c|}
\hline & $\begin{array}{l}\text { Date of latest } \\
\text { observation }\end{array}$ & $\begin{array}{c}\text { Date } \\
\text { received }\end{array}$ & $\begin{array}{c}\text { Frequency } \\
\text { of } \\
\text { data } 6 /\end{array}$ & $\begin{array}{l}\text { Frequency } \\
\text { of } \\
\text { reporting 6/ }\end{array}$ & $\begin{array}{c}\text { Frequency } \\
\text { of publication } \\
6 /\end{array}$ \\
\hline Exchange Rates & $5 / 19 / 10$ & $5 / 19 / 10$ & $\mathrm{D}$ and $\mathrm{M}$ & $\mathrm{D}$ and $\mathrm{M}$ & $\mathrm{D}$ and $\mathrm{M}$ \\
\hline $\begin{array}{l}\text { International Reserve Assets and Reserve } \\
\text { Liabilities of the Monetary Authorities } 1 /\end{array}$ & Mar 2010 & $4 / 15 / 10$ & $M$ & M & M \\
\hline Reserve/Base Money & Mar 2010 & $4 / 30 / 10$ & M & M & M \\
\hline Broad Money & Mar 2010 & $4 / 30 / 10$ & M & M & M \\
\hline Central Bank Balance Sheet & Mar 2010 & $4 / 30 / 10$ & M & M & M \\
\hline $\begin{array}{l}\text { Consolidated Balance Sheet of the Banking } \\
\text { System }\end{array}$ & Mar 2010 & $4 / 30 / 10$ & M & M & M \\
\hline Interest Rates 2/ & Mar 2010 & $4 / 30 / 10$ & M & M & M \\
\hline Consumer Price Index & Mar 2010 & $4 / 30 / 10$ & M & M & M \\
\hline $\begin{array}{l}\text { Revenue, Expenditure, Balance and } \\
\text { Composition of Financing } 3 /- \text { General } \\
\text { Government } 4 /\end{array}$ & 2009:Q4 & $3 / 31 / 10$ & Q & Q & Q \\
\hline $\begin{array}{l}\text { Revenue, Expenditure, Balance and } \\
\text { Composition of Financing } 3 /- \text { Central } \\
\text { Government }\end{array}$ & Jan 2010 & $4 / 30 / 10$ & M & M & M \\
\hline $\begin{array}{l}\text { Stocks of Central Government and Central } \\
\text { Government-Guaranteed Debt } 5 /\end{array}$ & Dec 2009 & $5 / 15 / 10$ & M & M & M \\
\hline External Current Account Balance & 2009:Q4 & $4 / 23 / 10$ & Q & Q & Q \\
\hline Exports and Imports of Goods and Services & Mar 2010 & $4 / 30 / 10$ & Q & Q & Q \\
\hline GDP/GNP & 2009:Q4 & $3 / 29 / 10$ & Q & Q & Q \\
\hline Gross External Debt & Jan 2010 & $3 / 31 / 10$ & M & M & M \\
\hline International Investment Position & 2009:Q4 & $3 / 31 / 10$ & Q & Q & Q \\
\hline
\end{tabular}

$1 /$ Reserve assets that are pledged of otherwise encumbered are specified separately. Data comprise short-term liabilities linked to a foreign currency but settled by other means as well as the notional values of financial derivatives to pay and to receive foreign currency, including those linked to a foreign currency but settled by other means.

2/ Both market-based and officially-determined, including discount rates, money market rates, rates on treasury bills, notes and bonds.

3/ Foreign, domestic bank, and domestic nonbank financing.

4/ The general government consists of the central government (budgetary funds, extra budgetary funds, and social security funds) and state and local governments.

$5 /$ Including currency and maturity composition.

6/ Daily (D), Weekly (W), Monthly (M), Quarterly (Q), Annually (A), Irregular (I); Not Available (NA). 


\section{Annex III. Croatia: World Bank Relations}

1. The World Bank's Board endorsed the Country Partnership Strategy (CPS) for Croatia for FY09-12 in September 2008, just before the full onset of the global financial crisis. The goal of the CPS is to support the completion of Croatia's EU accession process, the rapid convergence of its income level with that of current EU member states in a fiscally, socially and environmentally sustainable fashion. This overarching goal is in line with the Government's priorities expressed in various government programs. In pursuing this goal, the Bank Group program aims at contributing in the following four areas:

- $\quad$ sustaining macroeconomic stability;

- strengthening private sector-led growth and accelerating convergence with the EU;

- improving the quality and efficiency in the social sectors; and

- increasing the sustainability of long-term development.

2. The EU accession agenda remains a cross-cutting theme in the design and implementation of the Bank Group program. In the selection and design of operations, primary consideration is given to the assessment of proposed projects' support of Croatia's EU accession agenda. In the case of social sectors not covered under the EU acquis, consideration is also given to how projects complement the EU accession efforts. Project components that enhance Croatia's capacity to absorb EU funds, especially following the accession, have high priority.

3. The CPS envisages an indicative base-case lending envelope of about US\$1.01.4 billion for investment operations over the four-year period. The CPS also includes an upside scenario, with possible development policy lending amounting to some US\$1.41.8 billion. The lending program will be based on and complemented by analytical work, particularly in the areas of public expenditure reform, governance, investment climate, and climate change.

4. In FY10, the Bank's Board has approved three loans amounting to US\$475 million, to help mitigate the impact of the global economic crisis and provide funding for the private sector, through a credit line of about EUR100 million for exporters, , and through a Fiscal, Social and Financial Sector Development Policy Loan of EUR200 million. In addition, an investment operation for judicial sector has been approved. The future Bank program might be adjusted to help the authorities in implementing recently adopted Economic Recovery Program aiming to address the vulnerabilities and competitiveness issues of the economy.

5. Currently, the World Bank finances 19 operations in a wide range of sectors with a combined loan amount of close to US\$1.2 billion. IFC's portfolio amounts to about US\$335 million, and MIGA guarantees exceed US\$40 million. 


\section{Statement by the Staff Representative on the Republic of Croatia Executive Board Meeting June 21, 2010}

1. This statement reports on recent developments and adds to the information contained in the staff report for the 2010 Article IV consultation. It does not change the thrust of the staff appraisal.

\section{First quarter preliminary flash GDP estimates surprised on the downside,} highlighting the risks of weaker growth prospects for 2010 than what was assumed in staff's baseline scenario. GDP fell by $2 \frac{1}{2}$ percent year-on-year in the first quarter of 2010 vis-àvis staff's projected decline of $1 / 2$ percent. While there is significant uncertainty around these estimates and the demand components driving this decline are not known at this time, the staff now sees greater downside risks to the 2010 growth projection, with associated negative implications for unemployment, fiscal revenues and non-performing loans.

\section{The authorities have taken steps to implement reforms in all ten areas envisaged} under the Economic Recovery Program (ERP). In particular, the parliament has approved two laws to (i) reduce privileged pensions of selected groups, and (ii) rationalize the hospital network in Zagreb and reduce exemptions from health service copayments. Both laws will be effective from July 1, 2010. The combined annual fiscal savings from these two measures are estimated to be around 0.1 percent of GDP in 2010, and 0.3 percent of GDP per annum over the mediumterm. The stock of public enterprise arrears ( 0.3 percent of GDP in end-April) was reported to have been halved in May, helping alleviate the tight liquidity position of the corporate sector. The government has prepared amendments to the Income Tax Act to reduce the tax burden on labor income and eliminate numerous exemptions, and to the Profit Tax to increase the tax base and reduce evasion. Both proposals have been submitted to the Parliament for approval. ${ }^{1}$ The government has submitted amendments to the Labor Law to the Parliament with the objective to limit the duration of collective bargaining and eliminate the automatic extension of the collective agreements to entire sectors, and is currently in discussion with the labor unions to prepare further amendments. Non-tax levies were decreased to lessen the tax burden on businesses through amendments in a number of Acts. The authorities also received four bids for three of the shipyards slated for privatization, and are currently considering these offers.

\footnotetext{
${ }^{1}$ The amendments to the Income Tax Act propose three personal income tax rates, 12 percent (up to HRK 3,600), 25 percent (HRK 3,601- HRK 10,800), and 40 percent ( $>$ HRK 10,800), which replace the current four rates: 15 percent (up to HRK 3,600), 25 percent (HRK 3,601 - HRK 5,400), 35 percent (HRK 5,401 - HRK 16,200) and 45 percent ( $>$ HRK 16,200). The authorities intend to contain the negative impact of the rate changes on revenue collections through elimination of exemptions. The amendments to the Profit Tax Act include, among other things, elimination of personal expenses as tax deductibles, and expansion of the 20 percent rate to all types of services paid to companies not based in the EU or to companies based in countries where nominal profit tax rate is below 12.5 percent.
} 


\section{INTERNATIONAL MONETARY FUND}

EXTERNAL

Public Information Notice

RELATIONS

DEPARTMENT

Public Information Notice (PIN) No. 10/79

FOR IMMEDIATE RELEASE

June 21, 2010

International Monetary Fund

$70019^{\text {th }}$ Street, NW

Washington, D. C. 20431 USA

\section{IMF Executive Board Concludes 2010 Article IV Consultation with the Republic of Croatia}

On June 21, 2010 the Executive Board of the International Monetary Fund (IMF) concluded the Article IV consultation with Croatia. ${ }^{1}$

\section{Background}

The global economic and financial crisis has significantly affected the Croatian economy. With reduced capital inflows, and subdued export demand on the external front, and tight credit conditions on the domestic front, real GDP fell by 5.8 percent in 2009 , and unemployment rose sharply to 17 percent. While exports plunged, an even larger contraction in imports resulted in a near-halving of the current account deficit to 5 percent of GDP. The economy remains in the midst of a severe downturn in the early part of 2010, and positive growth is expected to resume gradually in the second half of the year, with a forecast for zero growth in 2010.

The authorities' policy response to the crisis has been swift. The Croatian National Bank (CNB) appropriately addressed liquidity shortages in the banking sector in 2009 through relaxation of regulatory requirements, repo auctions, and simplification of rules for banks to access CNB's emergency liquidity assistance. The timely policy response helped improve financial market sentiment: the kuna has fully retracted its losses, official reserves have been replenished, and bond spreads declined, which allowed the authorities to tap international capital markets twice in 2009. Liquidity pressures abated during the course of 2009 as domestic deposits remained stable and foreign parent institutions maintained their credit lines to domestic subsidiaries.

\footnotetext{
${ }^{1}$ Under Article IV of the IMF's Articles of Agreement, the IMF holds bilateral discussions with members, usually every year. A staff team visits the country, collects economic and financial information, and discusses with officials the country's economic developments and policies. On return to headquarters, the staff prepares a report, which forms the basis for discussion by the Executive Board. At the conclusion of the discussion, the Managing Director, as Chairman of the Board, summarizes the views of Executive Directors, and this summary is transmitted to the country's authorities.
} 
The authorities also took strong fiscal actions in 2009 to offset plunging revenues and contain the 2009 budget deficit to financeable levels. Three supplementary budgets were adopted with a number of short-term measures that included expenditure cuts, a wage and pension freeze, a VAT rate hike, and the introduction of a temporary "solidarity tax" on incomes and pensions. These measures, helped, but the fiscal deficit nevertheless widened to just under 4 percent of GDP (including the payment for a called guarantee of a public shipyard). Public debt also rose sharply to 50 percent of GDP including the guaranteed stock.

While banks have weathered the crisis relatively well owing to high capital buffers, profitability has decline largely reflecting an increase in the provisioning for nonperforming loans which reached 7.8 percent at end-2009. Private sector credit growth fell sharply as the uncertain macroeconomic environment lowered demand for new loans, and banks tightened underwriting standards. Concerns about the lack of credit recovery prompted the authorities to introduce earlier this year three schemes to revive credit to corporates, through loans to finance working capital as well as provision of government guarantees for investment loans. These schemes are expected to be in place until end-2010.

\section{Executive Board Assessment}

Executive Directors commended the authorities for skillfully navigating the economy through the global financial and economic crisis, as their swift intervention had helped preserve financial stability, contain the fiscal deficit, and maintain investor confidence and access to international capital markets. Directors noted the incipient recovery faces considerable downside risks given the uncertain global outlook, unsettled regional financial markets, and significant domestic economic vulnerabilities. Well-focused medium-term fiscal consolidation and ambitious structural reforms will be needed to increase competitiveness and attract investment to bring about stronger and more balanced growth.

Directors noted that the burden of demand management falls largely on fiscal policy, given the stable exchange rate policy. They agreed that a cyclically-balanced budget over the mediumterm would provide needed policy room and ensure debt sustainability. Directors considered that fiscal adjustment could be best achieved through expenditure measures, including reductions in the public sector wage bill and public enterprise subsidies, rationalization of pension and health expenditure, and better targeting of social assistance expenditure. They welcomed the inclusion of many of these measures in the Economic Recovery Program (ERP), while recommending that expenditure reforms should precede the envisaged tax cuts. In addition, Directors encouraged containment of rising contingent fiscal liabilities and endorsed plans to adopt a Fiscal Responsibility Law.

While recognizing the difficult trade-offs, Directors considered that maintaining a broadly stable exchange rate provides an appropriate anchor given market volatility and high financial euroization. They emphasized the importance of structural reforms to improve competitiveness, including by removing inefficiencies in the labor market and business environment, and pursuing appropriate income and wage policies to achieve internal adjustment of the economy. 
Directors recommended greater flexibility in employment policies and social benefits to remove adverse incentives for labor force participation. They also observed that improving the business environment would require privatization, reduced para-fiscal fees, and simplified business entry requirements. Directors welcomed the recent introduction of reforms in many of these areas under the ERP, noting that speedy, well-sequenced and full ERP implementation would be instrumental in strengthening market confidence and assisting Croatia in entering the EU from a position of strength.

Directors called for continued vigilant monetary and financial sector policies, as banks remain vulnerable to credit and liquidity risks. They viewed the moderate pace of monetary easing as adequate and cautioned against further easing as the financial outlook remains uncertain. While noting safeguards to prevent weakening of credit underwriting standards, Directors recommended close supervision of the quality of loans issued under the credit support measures. They expressed concerns about the recapitalization of public banks from the deposit insurance fund.

Public Information Notices (PINs) form part of the IMF's efforts to promote transparency of the IMF's views and analysis of economic developments and policies. With the consent of the country (or countries) concerned, PINs are issued after Executive Board discussions of Article IV consultations with member countries, of its surveillance of developments at the regional level, of post-program monitoring, and of ex post assessments of member countries with longer-term program engagements. PINs are also issued after Executive Board discussions of general policy matters, unless otherwise decided by the Executive Board in a particular case. 
Table 1. Croatia: Key Macroeconomic Indicators, 2005-11 1/

\begin{tabular}{|c|c|c|c|c|c|c|c|}
\hline & 2005 & 2006 & 2007 & 2008 & 2009 & $\begin{array}{l}2010 \\
\text { Proj. }\end{array}$ & $\begin{array}{l}2011 \\
\text { Proj. }\end{array}$ \\
\hline \multicolumn{8}{|l|}{ Output, unemployment, and prices } \\
\hline Real GDP & 4.2 & 4.7 & 5.5 & 2.4 & -5.8 & 0.0 & 2.0 \\
\hline Unemployment (labor force survey, in percent) & 12.7 & 11.1 & 9.6 & 8.7 & 9.2 & 9.5 & 9.0 \\
\hline CPI inflation (average) & 3.3 & 3.2 & 2.9 & 6.1 & 2.4 & 2.0 & 2.7 \\
\hline \multicolumn{8}{|l|}{ Saving and investment } \\
\hline Domestic investment & 28.0 & 29.8 & 30.5 & 32.8 & 28.3 & 30.2 & 30.6 \\
\hline Of which: fixed capital formation & 24.6 & 26.1 & 26.2 & 27.6 & 24.7 & 25.1 & 25.6 \\
\hline Domestic saving & 22.5 & 22.9 & 22.9 & 23.6 & 23.1 & 24.8 & 24.7 \\
\hline Government & 2.3 & 2.9 & 3.8 & 3.2 & 0.0 & -0.6 & -0.6 \\
\hline Nongovernment & 20.2 & 20.0 & 19.1 & 20.4 & 23.1 & 25.4 & 25.3 \\
\hline \multicolumn{8}{|l|}{ Government sector 2 I } \\
\hline General government revenue 2/ & 39.2 & 39.6 & 40.7 & 39.8 & 38.7 & 37.6 & 37.4 \\
\hline General government expenditure 2/ & 42.1 & 41.4 & 42.0 & 40.7 & 41.9 & 41.2 & 41.1 \\
\hline General government balance 2/ & -2.8 & -1.8 & -1.2 & -0.9 & -3.2 & -3.6 & -3.7 \\
\hline General government balance (broad definition) 2/ 3/ & -2.8 & -0.8 & -2.4 & -1.3 & -4.1 & -3.8 & -3.9 \\
\hline HBOR balance (net of budget transfers) & -0.1 & -0.2 & -0.5 & -0.1 & -0.6 & -0.6 & -0.6 \\
\hline Cyclically adjusted balance $2 /$ & -2.8 & -2.1 & -2.3 & -2.7 & -2.8 & -2.9 & -3.4 \\
\hline General government debt & 38.4 & 35.8 & 33.2 & 29.3 & 35.4 & 38.2 & 39.6 \\
\hline \multicolumn{8}{|l|}{ Money and credit } \\
\hline Bank credit to the nongovernment sector & 17.4 & 23.1 & 15.0 & 10.6 & -0.6 & $\ldots$ & $\ldots$ \\
\hline Broad money & 10.5 & 18.0 & 18.3 & 4.3 & -0.9 & $\ldots$ & $\ldots$ \\
\hline \multicolumn{8}{|l|}{ Interest rates $4 /$} \\
\hline Average kuna deposit rate (unindexed) & 1.7 & 1.7 & 2.3 & 2.8 & 3.2 & $\ldots$ & $\ldots$ \\
\hline Average kuna credit rate (unindexed) & 11.2 & 9.9 & 9.3 & 10.1 & 11.6 & $\ldots$ & $\ldots$ \\
\hline Average credit rate, foreign currency-indexed loans & 6.7 & 6.3 & 6.3 & 7.5 & 8.1 & $\ldots$ & $\ldots$ \\
\hline \multicolumn{8}{|l|}{ Balance of payments } \\
\hline Current account balance & $-1,976$ & $-2,715$ & $-3,237$ & $-4,371$ & $-2,361$ & $-2,505$ & $-2,888$ \\
\hline (In percent of GDP) & -5.5 & -6.9 & -7.6 & -9.2 & -5.2 & -5.4 & -5.9 \\
\hline Capital and financial account & 3,924 & 5,083 & 4,861 & 5,621 & 3,981 & 3,267 & 2,905 \\
\hline Overall balance & 822 & 1,412 & 722 & -330 & 896 & 262 & -583 \\
\hline \multicolumn{8}{|l|}{ Debt and reserves } \\
\hline Gross official reserves & 7,438 & 8,725 & 9,307 & 8,926 & 10,376 & 10,638 & 10,055 \\
\hline In percent of short-term debt (by residual maturity) & 85 & 88 & 109 & 69 & 71 & 74 & 80 \\
\hline In months of following year's imports of goods \& NFS & 4.5 & 4.9 & 4.7 & 6.0 & 6.7 & 6.5 & 5.8 \\
\hline Net international reserves & 5,604 & 6,464 & 7,349 & 7,849 & 9,365 & 9,947 & 9,364 \\
\hline External debt service to exports ratio (in percent) & 27.2 & 37.5 & 37.8 & 34.3 & 50.5 & 38.1 & 38.1 \\
\hline Total external debt (in percent of GDP) & 72.1 & 74.9 & 77.6 & 85.1 & 97.4 & 99.9 & 98.6 \\
\hline Net external debt $5 /$ & 37.7 & 38.7 & 41.1 & 48.6 & 60.8 & 63.3 & 62.0 \\
\hline \multicolumn{8}{|c|}{$\begin{array}{l}\text { Sources: Croatian authorities, and Fund staff estimates. } \\
1 / \text { National account data for } 1995-2008 \text { were revised in } 2009 \text {. Under the new ESA95 methodology, revised data include estimates for the "gray } \\
\text { economy," imputed dwelling rates, and financial intermediate services indirectly measured (FISIM). Revised nominal GDP figure for } 2008 \text { is } \\
\text { about } 14 \text { percent higher than the previous estimate. }\end{array}$} \\
\hline \multicolumn{8}{|c|}{ 2/ ESA 95 presentation. } \\
\hline \multicolumn{8}{|c|}{ 3/ Includes repayments of "pensioners' debt", and the balances of HBOR and HAC (net of budget transfers). } \\
\hline \multicolumn{8}{|c|}{ 4/ Weighted average, all maturities. Foreign currency-indexed loans are indexed mainly to euros. } \\
\hline
\end{tabular}




\section{Statement by Mr. Age Bakker, Executive Director on the Republic of Croatia June 21, 2010}

Like many countries in the region, Croatia faces challenging times in the aftermath of the crisis. The authorities value the continued close cooperation with the Fund, also in order to help addressing the challenges. They had productive discussions with staff in the context of the 2010 Article IV consultation, and broadly agree to their recommendations.

\section{The impact of the crisis}

As a small and open economy, Croatia was significantly affected by the global economic and financial crisis. The impact has been felt chiefly through a decline in external demand and private capital inflows, which until 2008 acted as the country's engine of growth. Admittedly, these inflows also fuelled rapid credit growth which led to higher domestic and external imbalances in the run up to the crisis. To safeguard macroeconomic and financial stability, the authorities promptly stabilized the foreign exchange market and provided liquidity at a time when foreign markets were effectively closed. By freezing wages and pensions as well as increasing direct and indirect tax rates, the authorities also contained the impact of the crisis on the 2009 fiscal balance. Helped by this welcome response, and the general improvement in risk appetite among investors, financial market conditions towards Croatia markedly recovered, as observed by the replenishment in reserves and narrowing sovereign bond spreads.

Although financial market sentiment improved in the course of 2009, GDP growth fell sharply by close to 6 percent, as the economy adjusted to lower capital inflows, tighter credit conditions and a collapse in exports. A broad gauge of seasonally-adjusted unemployment has also sharply increased from 13 percent in end-2008 to more than 17 percent early-2010, illustrating that the labor market is susceptible to output developments. Driven by import contraction, the current account deficit almost halved in terms of GDP between 2008 and 2009. Inflation retrenched amid the sizable negative output gap and lower energy and food prices.

\section{The economic outlook}

Croatia's economic prospects are challenging. While the recession has bottomed out, high frequency data suggest that the economy is likely to recover only modestly in the second half of 2010. Industrial output is showing some signs of improvement and exports are picking up, but private sector demand, particularly consumption, is likely to remain soft in the face of falling disposable incomes, rising unemployment, tighter credit conditions and the need to deleverage balance sheets. Against this background, the authorities broadly share staff's economic prospects for 2010, and its risk assessment which is skewed to the downside.

Although the current account deficit has fallen substantially, external financing requirements for 2010 remain substantial, particularly owing to large private sector debt repayments. These large requirements make Croatia potentially vulnerable to a reversal in sentiment. A mitigating factor however is that parent banks have until now remained fully committed to maintain exposures. Even during the crisis, these companies fully rolled over maturing private sector debt. Attracting 
funding for sovereign needs is likely to be manageable in light of the strong demand for government paper. So far, the impact of problems in Greece on Croatian funding costs has remained fairly limited, but the authorities are cognizant that wider euro area problems could trigger funding pressures for Croatian issuers.

\section{The policies}

EU accession remains the authorities' top priority, and entails a wide range of far-reaching administrative, social and economic reforms. The authorities are working vigorously to complete the legislative reforms in the context of EU accession negotiations by the end of this year, with the aim to enter the EU in 2012. In the view of the authorities, accession to the EU constitutes a significant step to further European integration with potentially large economic benefits. The authorities fully share staff's views that to reap the largest benefits of EU accession, Croatia needs to boost its competitiveness and secure wider macroeconomic policy space to future demand shocks. The government has therefore launched a comprehensive, far-reaching and multi-year Economic Recovery Program.

\section{Monetary and exchange rate policy}

For years Croatia's monetary policy has been aimed at maintaining a broadly stable nominal exchange rate in relation to the euro. Such a policy is appropriate, as it has served this small and open country well, also in view of its high level of euroization and strong financial integration with the rest of Europe. As staff rightly stresses, a stable nominal exchange rate has provided Croatia with a strong anchor for inflation expectations and financial stability. This policy is widely supported domestically. The authorities are of the view that the existing vulnerabilities are not the result of the stable exchange rate regime. Overleveraging in foreign currency occurred in many other countries in the region, irrespective of their exchange regime. Foreign currency lending in Croatia is related to the historically high level of foreign currency deposits, which dates back to periods of hyperinflation in the eighties and early nineties.

The authorities agreed with staff that given the sizable net foreign currency exposure of the corporate private sector even a moderate exchange rate adjustment would cause substantial negative balance sheet effects and credit losses. Such a shock would be costly in terms of output loss, partly due to non-linear effects triggered by a fall in confidence. The authorities do not consider it useful to target gradual exchange rate adjustment, as they are not convinced this would materially boost exports. Gradual adjustment would also be hard to engineer in the context of large cross-border capital flows and actors' high sensitivity to exchange rate movements.

Looking at both the benefits and costs, the authorities are strongly committed to maintaining the broadly stable exchange rate. In their view, the benefits of the current regime clearly outweigh the costs. Competitiveness needs to be improved were it should; and that is in the real sector. They fully realize that this will entail painful adjustments, but this is a price they consider well worth paying. The implementation of the Economic Recovery Program also demonstrates that the authorities are working on policies that support the current exchange rate regime. 
Fiscal Policy

Current conditions underscore the need of securing sustainable public finances and creating large enough fiscal room to address future economic shocks. The authorities are aware that action is needed. After an important improvement between 2004 and 2007, the cyclically-adjusted fiscal balance has deteriorated over the last couple of years, albeit to a lesser extent than in a number of other countries in the region. Originally, the 2010 fiscal deficit was expected to decrease substantially relative to the 2009 deficit on account of expenditure containment, but slower growth, the withdrawal of the solidarity tax and changes to the personal income taxes are likely to have a negative impact on revenues. The latter measures are part of the Economic Recovery Program and bring tax rates more in line with Croatia's peers. Limiting the impact of lower revenues requires compensatory measures. The authorities will reduce privileged pensions, save on health care spending through higher co-payments and hospital reorganizations and address corporate tax evasion. These measures become effective in July. They will undertake further measures, including abolishing most income tax exemptions and reducing a number of subsidies.

Going forward, medium-term fiscal consolidation will be supported by measures envisaged under the Economic Recovery Program. The authorities share staff's view that medium-term fiscal adjustment should be largely expenditure-based. In order to achieve that goal, they are committed to reducing the number of public-sector employees, for which the authorities have prepared the necessary legislation. Moreover, they are committed to downsizing the number of state agencies, outsourcing non-core government activities, speeding up privatization and reforming the pension, health care and social security system. The introduction of personal identification numbers last year will also help in better targeting social assistance.

\section{Financial Sector}

Conservative prudential and regulatory policies together with maintaining a stable exchange rate have proved to be of great value in safeguarding financial stability during the crisis. The banking sector remains resilient, despite the fact that nonperforming loans are on the rise. Profitability is declining, but is still at roughly 6.5 percent. While losses are likely to increase further due to slower growth, stress tests indicate that the banking sector is able to absorb a significant decline in asset quality, reflecting both decent profitability levels and very strong capital buffers. The aggregate capital adequacy ratio further increased to 18.9 percent in the first quarter of 2010, as a consequence of implementation of Basel II framework.

Croatian banks have large external liabilities, which make banks potentially susceptible to liquidity risks. However, as staff rightly stresses, foreign banks, coming from a diverse group of countries, have so far been strongly supportive of their subsidiaries in Croatia. Moreover, the high ratio of liquid assets to short-term liabilities further lowers liquidity risks. The authorities have taken note of staff concerns about the measures to stimulate bank lending. In the meantime, they have decided not to further ease monetary conditions to facilitate an increase in loan supply. They also stressed that the scheme to exchange debt for equity is only meant for companies with viable restructuring plans. It is not the intention of the government to hold on to these stakes for longer than necessary. 


\section{Structural reforms}

To improve competitiveness a number of structural reforms in the labor markets and business environment is required. The authorities' Economic Recovery Program recognizes the need to move forward in these areas. Croatia's unit labor costs rose faster relative to those in many of its trading partners over the last couple of years. However, adjustment is underway, as nominal net private-sector wages are dropping in response to growing labor market slack, and public-sector wages are frozen for this year. Non-competitive wage setting is also being tackled by the government, as they have recently submitted laws to the parliament to limit collective bargaining and eliminate the automatic extension of collective agreements. To help increase labor market participation, the authorities are taking legislative steps to limit the height and duration of unemployment benefits. The lower marginal income tax rates will also increase incentives to seek employment.

The authorities continue to work on improving Croatia's business environment. An interministerial working group will be established to identify all barriers to direct investment, and draft a plan to eliminate these barriers. One of the major factors adding to the cost of doing business is the high number of non-tax levies imposed by local governments on investors. The authorities have started to reduce these levies in the areas of utilities, tourism and real estate. In order to curb the government's footprint in public enterprises, the authorities are planning to sell their minority stakes in companies, for which legislation will be submitted to parliament by September this year. The authorities also received four bids for three of the shipyards scheduled for privatization.

The authorities consent to the Fund's publication of the staff report. 